$$
\begin{gathered}
\text { ORNL-3574 } \\
\text { UC-80 - Reactor Technology } \\
\text { TID-4500 (28th ed.) }
\end{gathered}
$$

SOME MAJOR FUEL-IRRADIATION TEST FACILITIES

OF THE OAK RIDGE NATIONAL LABORATORY

$$
\text { D. B. Trauger }
$$

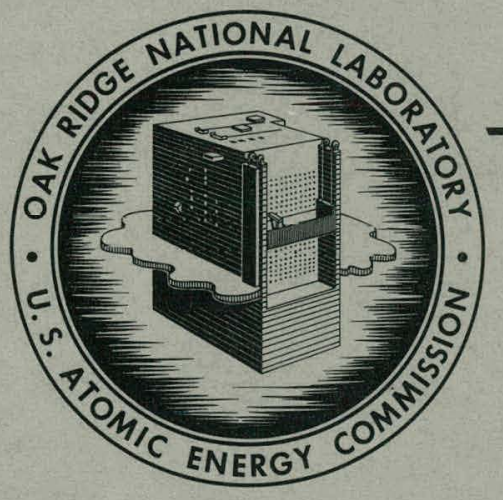

OAK RIDGE NATIONAL LABORATORY operated by

\author{
UNION CARBIDE CORPORATION \\ for the \\ U.S. ATOMIC ENERGY COMMISSION
}




\section{DISCLAIMER}

This report was prepared as an account of work sponsored by an agency of the United States Government. Neither the United States Government nor any agency Thereof, nor any of their employees, makes any warranty, express or implied, or assumes any legal liability or responsibility for the accuracy, completeness, or usefulness of any information, apparatus, product, or process disclosed, or represents that its use would not infringe privately owned rights. Reference herein to any specific commercial product, process, or service by trade name, trademark, manufacturer, or otherwise does not necessarily constitute or imply its endorsement, recommendation, or favoring by the United States Government or any agency thereof. The views and opinions of authors expressed herein do not necessarily state or reflect those of the United States Government or any agency thereof. 


\section{DISCLAIMER}

Portions of this document may be illegible in electronic image products. Images are produced from the best available original document. 
Printed in USA. Price: $\$ 2.50$ Available from the

Office of Technical Services

U. S. Department of Commerce

Wushington $25, \mathrm{D}$. C.

\section{LEGAL NOTICE}

This report was prepared as an account of Government sponsored work. Neither the United States, nor the Commission, nor any person acting on behalf of the Commission:

A. Makes any warranty or representation, expressed or implied, with respect to the accuracy, completeness, or usefulness of the information contained in this report, or that the use of any information, apparatus, method, or process disclosed in this report may not infringe privately owned rights; or

B. Assumes any liabilities with respect to the use of, or for damages resulting from the use of any information, apparatus, method, or process disclased in this report.

As used in the above, "person acting on behalf of the Commission" includes any employee or contractor of the Commission, or employee of such contractor, to the extent that such employee or contractor of the Commission, or employee of such contractor prepares, disseminates, or provides access to, any information pursuant to his employment or contract with the Commission, or his employment with such contractor. 
ORNL-3574

Contract No. W-7405-eng-26

Reactor Division

SOME MAJOR FUEL-IRRADIATION TEST FACILITIES OF THE OAK RIDGE NATIONAL LABORATORY

D. B. Trauger

APRIL 1964

OAK RIDGE NATIONAL LABORATORY

Oak Ridge, Tennessee

operated by

UNION CARBIDE CORPORATION

for the .

U.S. ATOMLC ENERGY COMMISSION 


\section{THIS PAGE}

\section{WAS INTENTIONALLY LEFT BLANK}


CONTENTS

List of Illustrations $\ldots \ldots \ldots \ldots \ldots \ldots \ldots \ldots \ldots \ldots \ldots \ldots \ldots \ldots \ldots \ldots$

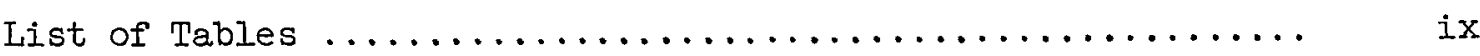

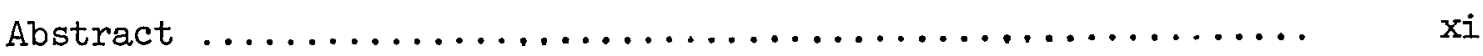

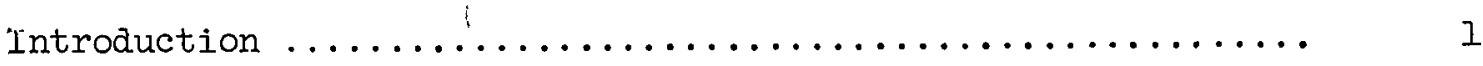

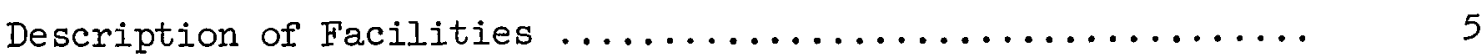

ORR Poolside Capsule Facility .................. 13

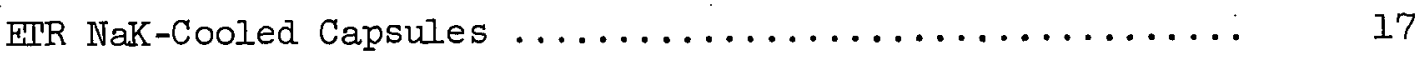

ORR Eight-Ball Capsule ...................... 27

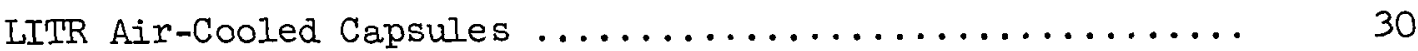

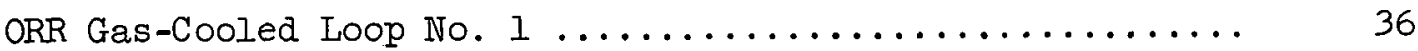

ORR Gas-Cooled Loop No. $2 \ldots \ldots \ldots \ldots \ldots \ldots \ldots \ldots \ldots \ldots \ldots$

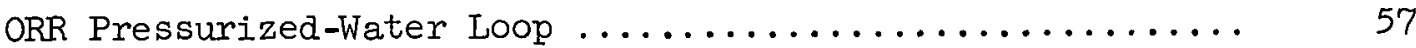

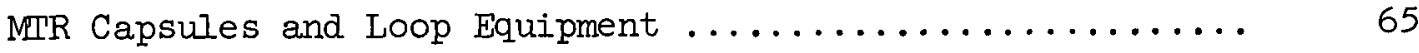

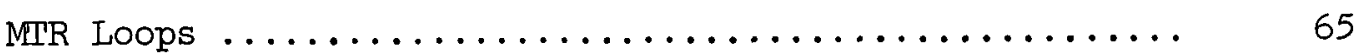

Molten-Salt Capsules ....................... 80

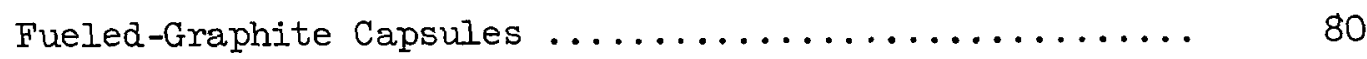

Shop Facilities for Capsule and Loop Assembly ......... 87

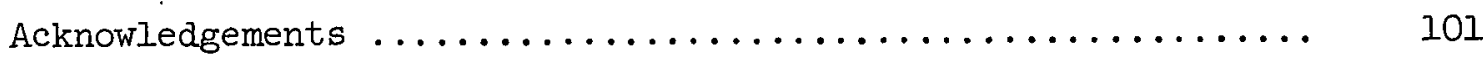

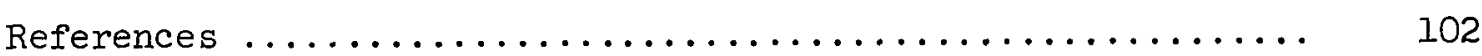


THIS PAGE

WAS INTENTIONALLY

LEFT BLANK 


\section{List of Figures}

Page

Fig. 1 Plan View of ORR Showing Location of Irradiation.

Equipment and Fuel Loading on June 30, 1963

Fig. 2 IITR Lattice Patterm and Locations for Experiments 8

Fig. 3 MIR Horizontal Section Showing Locations for Experi- 9 ments

Fig. 4 ETR Core Showing Location of ORNL Capsules with the

Fuel and Experimental Loading for Cycle 51B

Fig. 5 Overall View of ORR Pool Area Showing the Many Experimental Facilities Now Installed

Fig. 6 Enlarged View of Irradiation Equipment Installed in in the ORR

Fig. 7 Experimental Facilities for Irradiation of Full-

Diameter Prototype Fuel Capsules in the ORR

Fig. 8 EGCR Prototype Diameter Fuel Capsule for Irradiation in $\mathrm{ORR}$ and E'TR

Fig. 9 Capsule for Irradiating Spherical Fuel Elements

Fig. 10 ORR Poulside Capsule Gas Control and Sampling Systems

for Fuel Irradiations

Fig. 11 Sweep Capsule Sampling System

F1g. IZ2 Danghter-Trap Sampling W1re and Housing for ORR Poolside Capsules

Fig. 13 Sweep Capsule Assembly for Irradiation of 6-cm-diam

Spherical Fuel Flements in the ORR Poolside Facility

Fig. 14 Graphite Parts and Fueled Spheres for ORR Foolside Capsules

Fig. 15 Closeup Underwater View of ORR Poolside Capsules

Fig. 16 Instrument Control Panel for ORR Poolside and EightBall Experiments 
Fig. 17 Gamma-Ray Spectrometer for Loop and Capsule Experiments

Fig. 18 ORR Eight-Ball Assembly Showing Fueled Spheres Assembled in a Graphite Structure

Fig. 19 Eight-BaIl Capsule Parts

Fig. 20 LITR Capsules

Fig. 21 LITR Capsule Parts Prior to Assembly

Fig. 22 LITR Capsule for Irradiating Coated Particle Fuel

Fig. 23 IITR Capsule Access Tube to Direct Cooling Air Over

Fig. 24 Flow Diagram for LITR-GCR Experiments

Fig. 25 GCR-ORR Loop No. I Principal Components and Their

Relationship to the ORR Facility

Fig. 26 GCR-ORR Loop No. I Schematic Flow Diagram

Fig. 27 HECT-II Compressor for GCR-ORR Loop No. I

Fig. 28 Typical Temperature Distribution for GCR-ORR Loop No. 1

Fig. 29 Typical Test Fuel Element for Helium-Cooled Loop

Tig. 30 GCR-ORR Loop No. I Loading Station

Fig. 31 Loop In-Pile Section

Fig. 32 Loop No. I Fuel Element and Shroud

Fig. 33 Oak Ridge Research Reactor with Gas-Cooled Reactor Experiments Underway

Fig. 34 GCR-ORR Loop No. I Instrument Panel

Fig. 35 Assembly for Tests of Fueled-Graphite Spheres in GCR-ORR Loop No. 2

Fig. 36 GCR-ORR Loop No. 2 In-Pile Section

Fig. 37 Composite Flow Diagram of GCR-ORR Toop No. 2

Fig. 38 Diagram of GCR-ORR Loop No. 2 
Fig. 39 View of Loop No. 2 Equipment in the Containment Cell 55

Fig. 40 Instrument Control Panel for Loop No. 2

Fig. 41 Pressurized-Water Loop in the ORR 58

Fig. 42 Simplified Flow Diagram of Pressurized-Water Loop 60

Fig. 43 In-Pile U-Tube Assembly for Pressurized-Water Loop 61

Fig. 44 Two Three-Pin Assemblies for Irradiation in the Pres- 62 surized-Water Loop

Fig. 45 Army-Martin Stainless Steel Dummy Fuel Specimens 63

Fig. 46 Operating Area for ORR Pressurized-Water Loop 64

Fig. 47 Fixture for Underwater Examination of Fuel Flements 66

Fig. 48 Diagram of Circulating-Fused-Salt Fuel Irradiation 69 Test Loop

Fig. 49 Flow Diagram for ORNL-MIR-44 Circulating-Fused-Salt 70 Fuel Irradiation Test Loop

Fig. 50 Fuel Pump for Fused-Salt In-Pile Loop . 71

Fig. 51 Irradiation Facility at the MIT HB-3 Beam Hole 72

Fig. 52 Overall View of Molten-Salt Loop with Shielding Plug 73 Attached

Fig. 53 Closeup of Molten-Salt Loop Nose Coil with Heaters $\quad 74$ Installed and Thermocouples Attached

Fig. 54 Forward End of Molten-Ealt Luop as As'sembled Without 75 Water Jacket

Fig. 55 Overall View of Molten-Salt Loop Assembly Without 76 Water Jacket

Fig. 56 Completed Molten-Salt Loop on Assembly Fixture 77

Fig. 57 Sampling Station for Removal of Large Bottles of 78 Radioactive Gas for Chemical Analysis

Fig. 58 Instrument Panel for MIR Facility 79

Fig. 59 Assembled Molten-Salt-Fueled Capsules Prior to In- 82 stallation in Sodium-Filled Can 
Fig. 60 Purged Capsule Containing Graphite Submerged in Molten-Salt Fuel

Fig. 61 ORNL-MTR-47-3 Molten-Salt-Fueled Capsule Test Assembly 84

Fig. 62 ORNL-MIR-48 Capsule and Plug Assembly for Advanced GCR 85 Fuel-Element Irradiation Tests

Fig. 63 Assembly for Graphite Matrix Fuel Element and Loose Coated-Particle Irradiation in the MTR Capsule Facility

Fig. 64 Plan View of Shop and Assembly Area

Fig. 65 Tnstrumented Fuel Assembly for EGCR

Fig. 66 Tungsten vs Rhenium Thermocouple Assembly with BeO Insulation

Fig. 67 Instrument Mechanic Preparing Sheathed Thcrmocouple for Welding of Insulated Junctions

Fig. $68^{\circ}$ Welder Making Thermocouple Junctions with Semiautomatic Welding Equipment

Fig. 69 Closeup of Binocular Microscope and Blasting Gun Used to Prepare Sheathed Thermocouples for Welding Insulated Jinctions

Fig. 70 Helium Leak Checking a Container with Mass Spectrometer-Type Leak Detector

Fig. 71 Brunson Optical Tooling Equipment

Fig. 72 Loop 1-S In-Pile Section on Assembly Fixture 98

Fj.g. 73 ORR Poolside Facility Mockup Showing ORR Capsule in 99 Positioning Mechanism Which Duplicates Installation at the Reactor

Fig. 74 Blickman Welding Chamber in Assembly Area 
List of Tables

Page

Table 1 Capabilities of Irradiation Test Facilities 3

Table 2 Gas-Cooled Reactor Program Capsule Irradiation Tests, 18 July 1958 Through September 1963

Table 3 Capacity of ORR Gas-Cooled In-Pile Loops 41

Table 4 Tests Conducted in Loop No. 1

Table 5 Fuel Tests Conducted in Loop No: 2

Table 6 Experiments Conducted in the ORR Pressurized-Water 67 Loop

Table 7 In-Pile Loop Tests of Circulating-Molten-Salt Fuel 68

Table 8 Molten-Salt-Fuel Irradiation Tests 81

Table 9 Fueled-Graphite Capsules Irradiated in the MTR 88 
THIS PAGE

WAS INTENTIONALLY

LEFT BLANK 
Irradiations of test fuel specimens and experimental fuel elements are conducted both in capsules and in forced-convection-cooled loops. The design of equipment suitable for irradiation tests pertinent to the development of boiling- and pressurized-water, gas-cooled, sodium-cooled, and molten-salt reactors is described briefly, with particular emphasis on test capability.

The capsules utilize thermal conduction through sodium or $\mathrm{NaK}$, gasfilled annuli, and graphite for heat removal from the fuel element surface. Six basic designs have been employed, with many variations, in conducting over 125 separate irradiation experiments. Capsule features include external pressurization to 900 psia, sweep gas for fission-gas removal, fission-gas sampling and daughter-trap collection for gamma-ray spectrometer analysis, continuous flux monitoring and control, and measurement of temperatures up to $4000^{\circ} \mathrm{F}$.

The loop facilities described are: (1) a pressurized-water loop for operation up to 2500 psia and $625^{\circ} \mathrm{F}$ with heat removal up to $300 \mathrm{kw}$; close control is provided over water chemistry; (2) two helium-cooled loops capable of operation up to a gas temperature of $1500^{\circ} \mathrm{F}$, a system pressure of $300 \mathrm{psia}$, and fission and gamma heating of $60 \mathrm{kw}$; other coolants can be accommodated, and the loops are designed to operate with fissionproduct contamination when necessary; (3) a compact loop design for recirculating molten-salt fuels at high temperatures.

Design features to meet safety requirements, alteration of equipment to accommodate changing program needs, and factors affecting the economics of operation are discussed briefly. The close relationship needed between the irradiation test laboratory and fuel development programs is indicated. The usefulness of assistance from other related groups in a large laboratory complex is mentioned. Finally, shop facilities are described for meeting the exacting needs of irradiation capsule assembly. 


\title{
SOME MAJOR FUEL-IRRADIATION TEST FACILITIES OF THE OAK RIDGE NATIONAL LABORATORY
}

\author{
D. B. Trauger
}

\section{INTRODUCTION}

The Oak Ridge National Laboratory from its inception has been engaged in the development of reactors and reactor fuels. Important to this phase of ORNL work is the testing of fuels under conditions which simulate the intended service in a power-producing reactor. Achievement of appropriate test conditions was first made possible by the development of test reactors which produce high neutron fluxes. Early tests were conducted in the $\mathrm{LITR}^{1}$ and the $\mathrm{MIR} ;^{1-2}$ later experiments were designed to utilize the $\mathrm{ORR}^{3}$ and the EIR, ${ }^{4}$ which afford more versatile arrangements for engineering-scale tests. ORNL irradiation test rigs are now concentrated in the ORR and LITR, where various test positions are utilized, including in-core, poolside, and beam-hole facilities. Other reactor space is used as required to obtain additional space or particular features.

The text of this report is intended to provide a brief but basic description of the irradiation facilities. It is hoped that it will be particularly useful to those engaged in related fields, such as fuel development, and for program planning. This report also illustrates the diverse equipment which is available and indicates the capability of a national laboratory to conduct the irradiation-testing phase of reactor development programs. For those directly interested in irradiation test work, this report will serve only for reference purposes; it is not intended to provide the detail necessary for improvement or duplication of test equipment.

The fuel-irradiation test facilities described have been the responsibility of the Trradiation Engineering Department of the Reactor Division. They were designed to provide appropriate environments for several powerproducing reactor systems, and their primary application has been to evaluate fuel and fuel element concepts which are advanced beyond proven practice. Experiments are conducted in these facilities to determine the effects of nuclear processes, including radiation damage, fission-product generation, and transmutation, particularly as related to other variables. Important nonnuclear factors include temperature, thermal stress, pressure stress, differential thermal expansion, and chemical and metallurgical properties. Specific prohlems involve changes in metallurgical structure, interactions between fuel and its cladding or container, buildup of pressure by volatile fission products, and the movement or redistribution of radioactive materials within the fuel system. The equipment described in this report has been used for the investigation of variables affecting 
fuel element design, for proof testing of prototype fuel assemblies, and for studies involving reactor coolants. Reference is made in the text to documents which describe the program requirements and fuel development work for which the irradiation facilities were designed.

Equipment is available for tests of both the solid and the liquid fuels under development for use in thermal and fast reactors. Both liquid and gas coolants can be employed. Most of the irradiation rigs have been utilized repetitively, with both major and minor revision to accommodate changing program needs. In each revision, capability for the earlier purpose was retained where possible, and thus highly versatile equipment has been developed. A list of the irradiation facilities, identified by the test reactor, and the number of experiment stations is given in Table 1 . The EIR and MIR capsules are in the reactors of corresponding title, which are located at the National Reactor Testing Station in Idaho; the others are located at ORNL.

Varied technical skills are requircd to effectively plan irraxiation test work. Designers, experienced analysts, project engineers, and trained operating crews comprise the team for conducting experiments. Extensive assistance from other groups at ORNL is used to complement the effort of the Irradiation Engineering Department and provide strong support. This includes work in reactor analysis, radiation shielding, metallurgy and ceramics, welding and brazing, inspection, analytical chemistry, instrumentation, health physics, and reactor operations. Related tests frequently are conducted by other groups and coordinated with the irradiation studies. Shop facilities and other services from the $\mathrm{Y}-12$ and ORGDP plants are also used extensively. Test programs may be initiated and directed either by the Irradiation Engineering Department or, more frequently, by other ORNL groups engaged in reactor or fuel development.

Considerable attention is given to reliability of equipment and safety. The principle of double containment by use of independent vessels or structures is followed to ensure that radioactivity is not released in the event of accident or malfunction of equipment. Very few deviations from this principle are permitted, and monitoring normally is provided to show that both the primary and secondary vessels are intact. Most experiments uti.i.ize the reactor safety system to prevent. serious accident conditions in the event of equipment malfunction, but ultimate safety is provided by containment. Vessels are built and inspected according to the standards of applicable codes.5-8

Irradiation test equipment in general is diffisult. or, in many casee, impossible to alter or repair during or following operation. Out-of-pile tests of both equipment and experimental elements are therefore conducted whenever practical and where significant conditions can be attained. Thorough checking and evaluation of in-pile equipment contribute greatly to reduction of costs by assurance of successful experiments through satisfactory operation. Despite precautions, many difficulties have been encountered in conducting the irradiation experiments described. It may be stated conservatively, however, that this equipment has performed well and, in general, has met its test requirements satisfactorily. 
Table 1. Capabilities of Irradiation Test Facilities ${ }^{a}$

\begin{tabular}{|c|c|c|c|c|c|c|c|c|}
\hline \multirow{2}{*}{ Facility } & \multirow{2}{*}{$\begin{array}{l}\text { Number } \\
\text { of } \\
\text { Stations }\end{array}$} & \multirow{2}{*}{$\begin{array}{l}\text { Maximum } \\
\text { Number of } \\
\text { Test } \\
\text { Elements }\end{array}$} & \multicolumn{2}{|c|}{$\begin{array}{l}\text { Maximum Fuel } \\
\text { Dimensions (in.) }\end{array}$} & \multicolumn{2}{|c|}{$\begin{array}{c}\text { Maximum Temperature } \\
\left({ }^{\circ} \mathrm{F}\right)\end{array}$} & \multirow{2}{*}{$\begin{array}{c}\text { Maximum } \\
\text { Thermal } \\
\text { Neutron Flux } \\
\text { (neutrons } / \mathrm{cm}^{2} \cdot \mathrm{sec} \text { ) }\end{array}$} & \multirow{2}{*}{$\begin{array}{l}\text { Statior } \\
\text { Maximun } \\
\text { Power } \\
\text { (kw) }\end{array}$} \\
\hline & & & Diameter & Length & $\begin{array}{c}\text { Fuel } \\
\text { Surface }\end{array}$ & Coolant & & \\
\hline LITR capsules & 7 & 28 & 0.375 & 3 & $1300^{c}$ & 400 & $2 \times 10^{23}$ & 1 \\
\hline ORR poplside capsules & 8 & 8 & 3 & 12 & $1600^{\mathrm{d}}$ & $1600^{e}$ & $7 \times 10^{13}$ & 20 \\
\hline ETR capsules & 14 & 14 & 0.75 & 18 & 1600 & $1600^{e}$ & $8 \times 10^{13}$ & 30 \\
\hline $\begin{array}{l}\text { ORR eijht-ball fa- } \\
\text { cility }\end{array}$ & 1 & 1 & 1.5 & 16 & 2500 & $2500^{e}$ & $1 \times 10^{14}$ & 20 \\
\hline ORR helium loop No. I & 1 & 1 & 0.875 & 18 & $1600^{f}$ & 1400 & $8 \times 10^{13}$ & 60 \\
\hline ORR helium loop No. 2 & 1 & 1 & 2.75 & 9 & $2500^{g}$ & 1500 & $1 \times 10^{13}$ & 20 \\
\hline $\begin{array}{l}\text { ORR pressurized-water } \\
\text { loop }\end{array}$ & 2 & 33 & 1.5 & 19 & 700 & $625^{\mathrm{h}}$ & $7 \times 10^{13}$ & $150^{\mathrm{h}}$ \\
\hline MIRR capsules and loop & 1 & 6 & 3 & 6 & $2500^{g}$ & $1600^{e}$ & $1 \times 10^{14}$ & 30 \\
\hline
\end{tabular}

Wot all maximum limits are attainable simultaneously.

$b_{F u e l}$ central temperatures can be measured in all facilities except the ETR capsules; maximum temperature measured to date is $4200^{\circ} \mathrm{F}$.

${ }^{C}$ Capsule temperature; fuel outer surface may be much higher, $\sim 3000^{\circ} \mathrm{F}$ maximum to date.

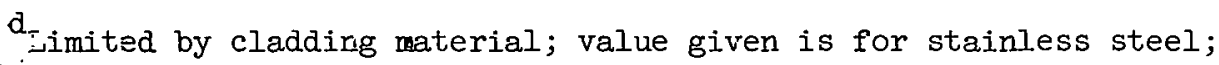
$2500^{\circ} \mathrm{F}$ can be achieved for graphite-matrix fuels.

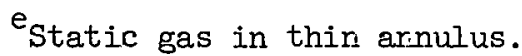

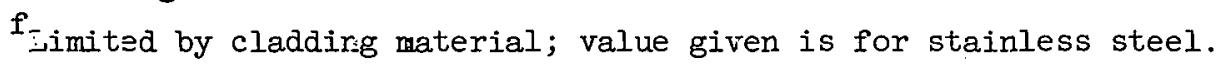

gimit determined by rature of fuel under test; value given is nominal for graphite-matrix fuels.

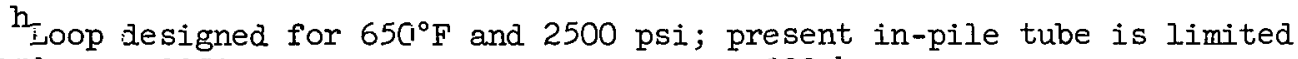
to $625^{\circ} \mathrm{F}$ and $2250 \mathrm{psi}$; totel loop capacity is $300 \mathrm{kw}$. 
The design, and therefore description, of irradiation equipment necessarily includes consideration of hot-cell facilities and techniques. Although some reference is made to hot-cell requirements, detailed discussion of postirradiation examinations is outside the scope of this report. However, for completeness, references are listed which describe ORNL hot-cell equipment and the facilities used with this irradiation equipment. The $\mathrm{ORR}$ hot cell to which experimental equipment from the reactor core or poolside can be removed directly through the pool without the use of casks or shielding other than the pool water is described in ref. 9. This cell location provides convenient means for early inspection of irradiated equipment. A large cell has been provided for handling beam hole and other major assemblies and for temporary operation of radioactive equipment of small pilot-plant scale.10 Specialized equipment for sectioning materials and detailed examination has been provided in cell No. 6 , which can accommodate alpha contamination. ${ }^{11}$ Smaller cells are available for radiography and other analytical work. A new facility is nearing completion which will accommodate a large volume of work, including close inspection, specialized disassembly, and detailed examination. 12

Initial dismantling of equipment irradiated at the MIR is handled in cells at NRTS. Many of the experimental assemblies listed in this report were examined in hot cells at GEVAL (General Electric Vallecitos Atomic Laboratory) and at BMI (Battelle Memorial Institute). 


\section{DESCRIPTION OF FACILITIES}

The two classifications, capsules and loops, employed in describing irradiation test equipment are distinguished by the method of heat transfer from the fuel surface. In capsules, heat transfer is principally by conduction, whereas loops employ convection cooling, usually by a recirculating coolant forced by pumps or compressors. By their simplicity, capsule facilities are less costly to construct and operate, but they do not simulate the reactor service as realistically as loops. Various arrangements for both types of equipment are employed at oRNL. Each facility has been somewhat specialized to provide for specific test needs. The various units are complementary so that a major fuel development program can be conducted quickly with adequate irradiation test support. Replication of the simpler facilities provides capacity for handing several programs simultaneously.

The LITR capsules are small test systems designed particularly for accelerated experiments or for screening of materials. Although cooled by forced convection, the compressed air is used only for convenience. Seven stations are available, and each is capable of containing as many as four encapsulations of fuels, including metals, alloys, ceramics, such as $\mathrm{UO}_{2}$, UC, and $\mathrm{UN}$, and coated particles.

The ORR capsules are highly versatile units in which many different kinds of fuel can be irradiated under more complex test conditions. A wide range of environments can be provided for fuel elements, including gases and liquid metals, high external pressures, and thermal cycling. Full-size fuel sections (except as limited in some cases by length) can be accommodated so that highly definitive tests are possible. The ORR eight-ball and the EIR capsule units have similar capabilities but are limited in size and in neutron flux control by their locations in reactor core and reflector positions, respectively. However, these locations provide higher neutron flux levels and excellent heat-removal capabilities for conducting tests at high power densities.

The facility now at the MIR was developed for a complex loop operation before the ORR was available and has since been altered to provide diverse capabllity to meet many fuel test requirements. Both package loops and capsules can be accommodated at the MTR. The HB-3 beam hole has been used for the experiments; however, the out-of-pile equipment could be used with other test positions.

The ORR loops afford more complete simulation of reactor conditions, since dynamic forces, nonuniformity of cooling, and the effect of expected impurities in reactor coolants can be included. The two gas loops complement each other in providing a considerable range of neutron flux intensity, specimen size, heat removal, gas coolant chemistry, and simulation of reactor system features. The pressurized-water loop provides many features of both pressurized-and boiling-water reactors and can handle elements having large heat-generation ratings. Operation of the 
three loops in common effects considerable savings in operator and maintenance costs. Furthermore, the three loops and, to some extent, the capsules also utilize common equipment and services. When savings are accomplished in this manner, long-range planning is desirable because each facility is affected by the program for the others. Important advantages, however, are the justification of greater service facilities and pooling of technical talent. Experiences gained by one task engineer in a closely knit group directly strengthens the work of others.

Figures 1 through 4, respectively, show plan views of the ORR, LITR, MTR, and ETR reactors and the locations of equipment described. The complexity of an actual installation is illustrated in the photographs of the ORR pool in Figs. 5 and 6.

Capability now exists for conducting approximately 50 simultaneous engineering-scale irradiations of experimental nuclear reactor fuels. Each may be conducted under a unique set of conditions, although several may arbitrarily be made essentially identical for replication or for comparative experiments. The heat-removal capabilities of individual facilities and the available neutron fluxes are given in Table 1.

Tests may be conducted with various coolants in contact with fuel or cladding, including air, argon, $\mathrm{CO}_{2}, \mathrm{He}, \mathrm{N}_{2}, \mathrm{Na}, \mathrm{NaK}$, and water. ORR loop No. 1 is adaptable to hydrogen cooling, although irradiation tests with this gas have not been conducted to date. Instrumentation is available to measure fuel temperatures reliably up to $3000^{\circ} \mathrm{F}$ and with less certainty to $4000^{\circ} \mathrm{F}$. Independent control of both neutron flux and temperature has been achieved for some of the facilities, including both capsules and loops. The general capabilities are given in Table 1. The equipment described in this report has been utilized for the irradiation of more than 300 separate fuel capsules during the past five years.

In addition to the specialized facilities, hydraulic rabbit tubes and noninstrumented capsules in test reactor core positions may be used for irradiations. Rabbit facilities are satisfactory for many irradiations and are utilized when possible because relatively little cost is involved. ${ }^{13}$ However, the limited range of conditions achievable and the obvious simplicity of the noninstrumented assemblies place them outside the scope of this report. Tests also may be conducted by placing experimental elements directly in the core of a reactor test facility or in a power reactor. Such tests are limited to relatively well-proven devices, since a large installation might be adversely affected by failure of the element. Also, it is not possible to vary test conditions in a power reactor adequately for many needs of development programs.

Not all irradiation equipment of ORNL has been included in this report. In general, the larger equipment currently utilized in direct support of Reactor Division programs is described. Many other facilities are available for materials studies and for testing specific properties of fuels. 13 


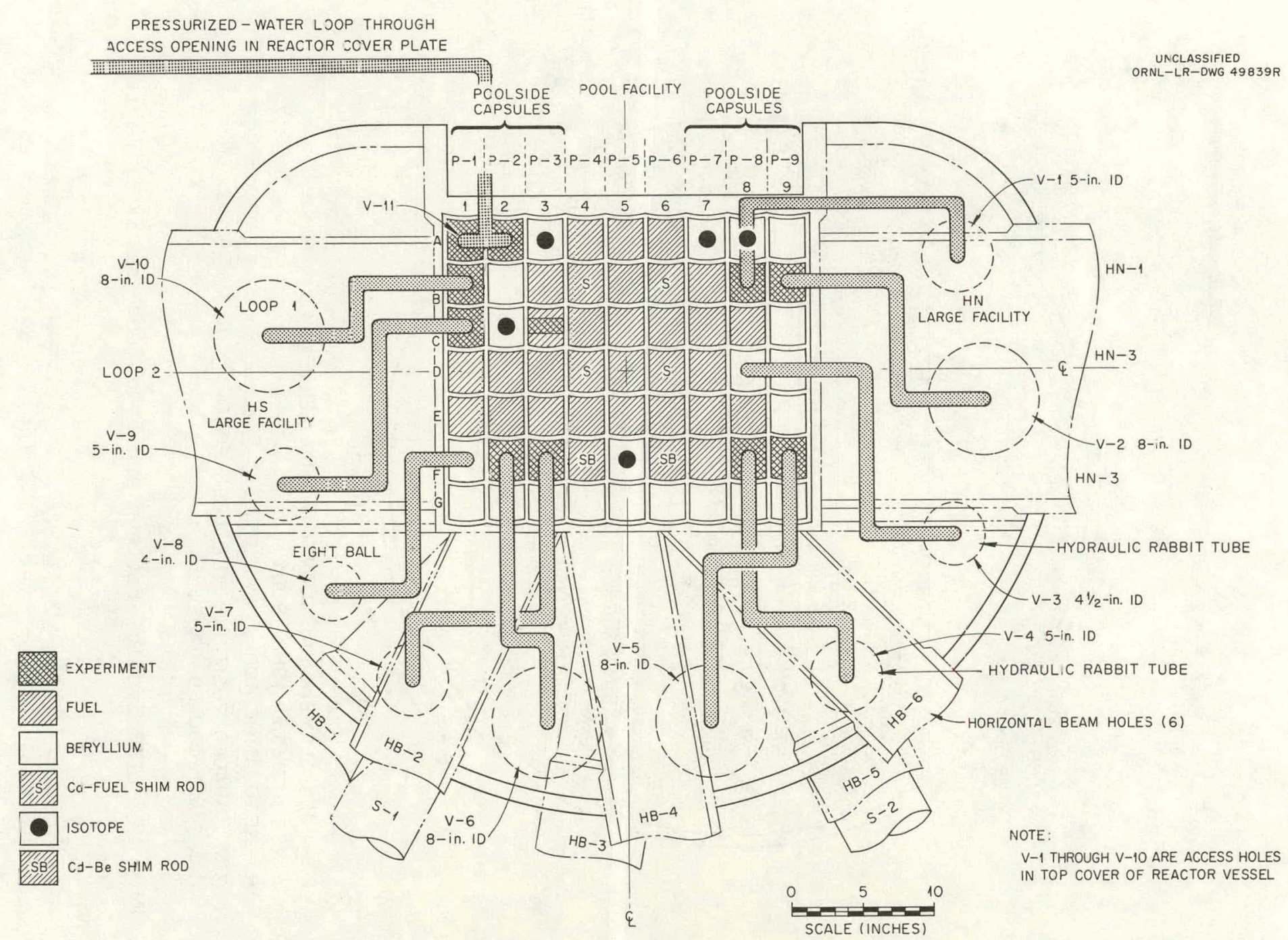

Fig. 1. Plan View of ORR Showing Location of Irradiation Equipment and Fuel Loading on June 30, 1963. 


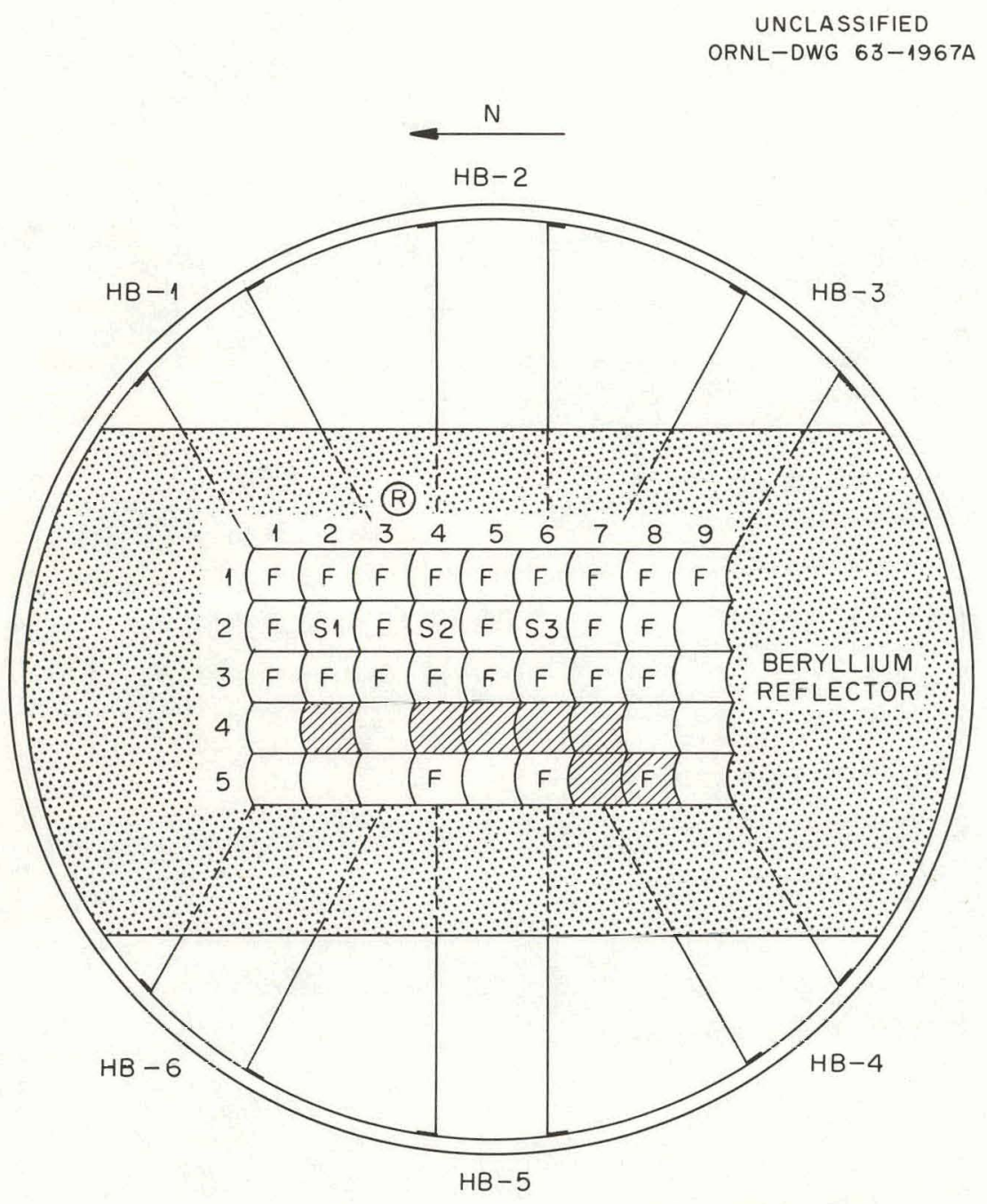

F - FUEL ELEMENT (INCLUDING PARTIAL ELEMENTS)

S1, S2 AND S3 - SHIM RODS

R - REGULATING ROD

SHADED POSITIONS ARE USED FOR

AIR-COOLED CAPSULES

Fig. 2. LITR Lattice Pattern and Locations for Experiments. 
Unclassified.

ORNL-DWG 64-1443

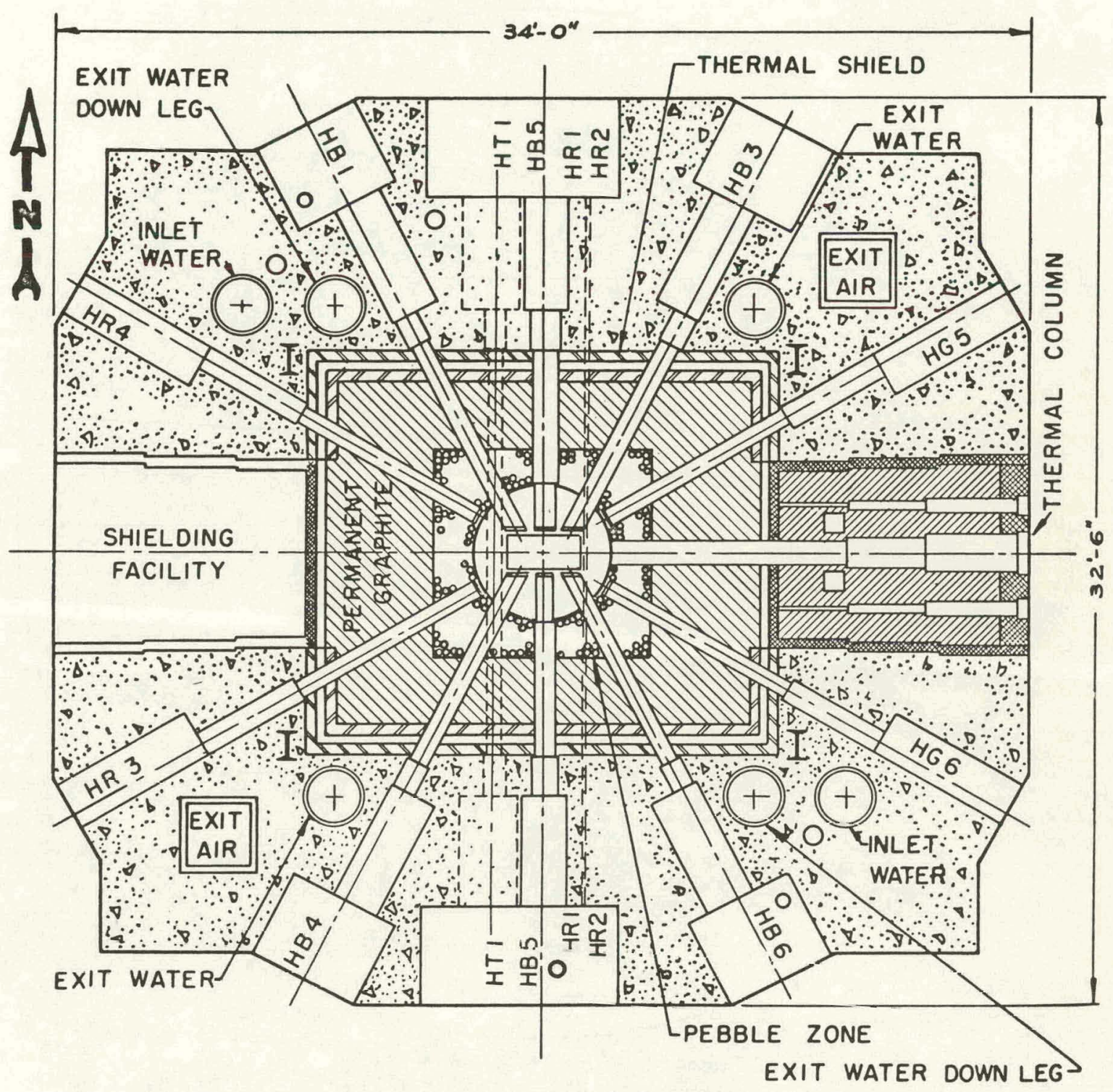

ments.

Fig. 3. MPR Horizontal Section Showing Locations for Experi- 
UNCLASSIFIED

ORNL DWG. 64-1386

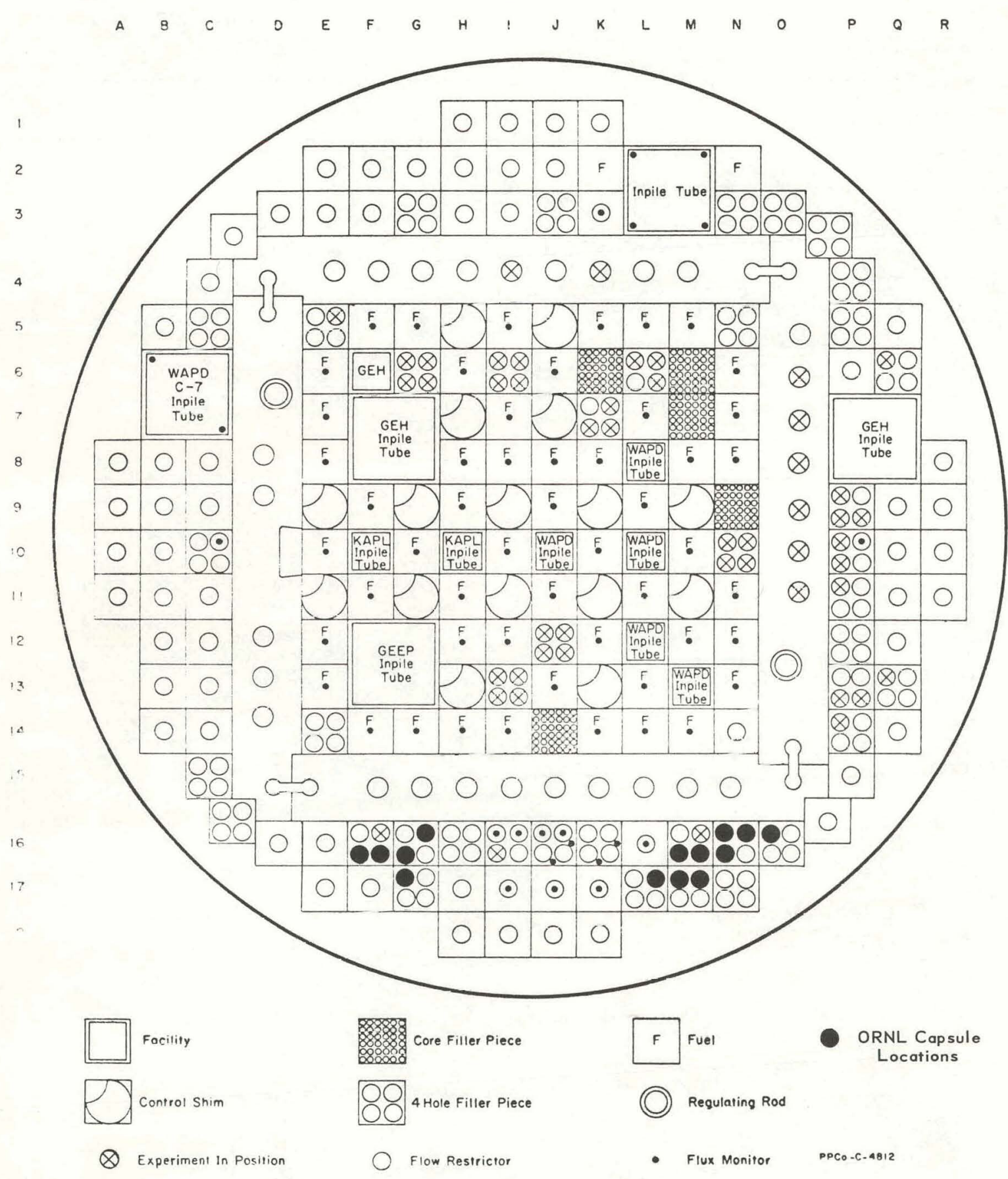

Fig. 4. EIR Core Showing Location of ORIL Capsules with the Fuel and Experimental Loading for Cycle 51B. 


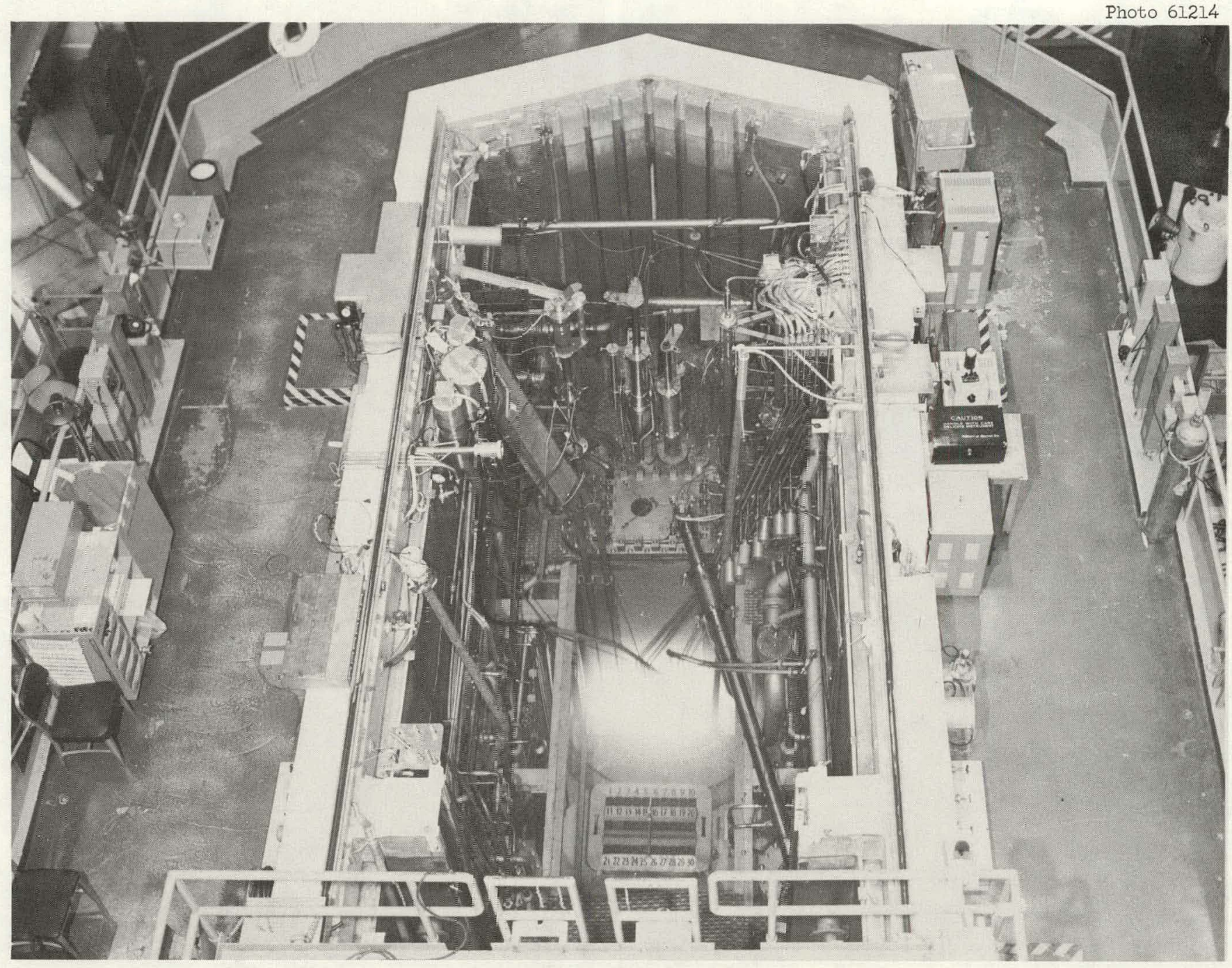

Fig. 5. Overall View of ORR Pool Area Showing the Many Experimental Facilities Now Installed. Other equipment, particularly for beam-hole experiments, is located. on the floor below, on the lower salcony, and in the basement. 
Unclassifien

Thulu $612 \perp b$

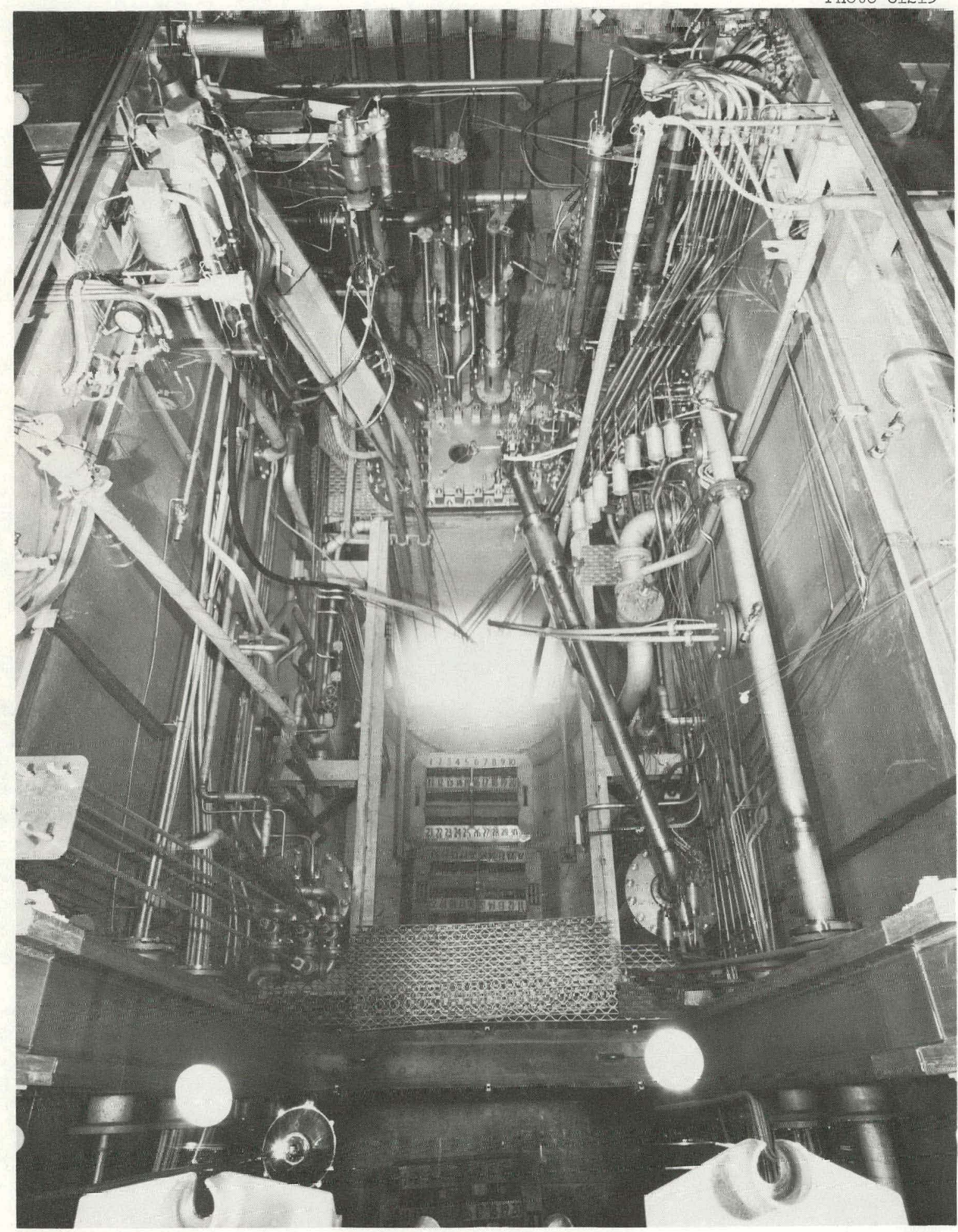

Fig. 6. Enlarged View of Irradiation Equipment Installed in the ORR . 


\section{ORR Poolside Capsule Facility}

The ORR has a large high-flux irradiation facility outside the reactor tank. This was achieved by providing a flattened and indented section of the reactor tank adjacent to one side of the core. Since the ORR tank is immersed in a large pool of water, direct access is available to a large volume having a high neutron flux density. The water shielding pool provides visibility and space for movement of equipment without restriction. This arrangement has proved most useful for conducting capsule tests.

The poolside capsule irradiation facility is shown diagramatically in Fig. 7. It was developed for the EGCR fuel-irradiation program ${ }^{14}$, I5 but has since been extended for testing several configurations and sizes of both clad and all-ceramic fuel elements.16-19 As many as eight separate fuel assemblies can be accommodated simultaneously in separate containers; however, when the fuel specimens exceed 1 in. in diameter, their number must be reduced.

Basically, the irradiation capsules are of concentric double-wall metal construction and utilize either NaK or graphite to conduct heat from the fuel specimen to the inner container. A thermal barrier in the form of a gas gap between the inner and outer containers provides the resistance necessary to achieve high temperatures during irradiation. The heat energy is rejected from the outer wall to the reactor pool. Measurement of gas pressure in the annulus is a means for monitoring the integrity of the vessels, which also serve as containment for safety requirements. Fuel element cladding surface temperatures up to $1600^{\circ} \mathrm{F}$ can be attained in present capsules with the specimen immersed in NaK, as shown in Fig. 8. Higher surface temperatures can be achieved at the test fuel element surface by using other matcrials of construction or by placing the element inside a second gas-filled annulus. Temperatures are measured by thermocouples inserted in the $\mathrm{NaK}$ or the graphite inner structure.

Irradiutions of fuel. in a graphite matrix have been conducted at surface temperatures up to $2500^{\circ} \mathrm{F}$. A capsule for irradiating fueled-graphite spheres is shown in Fig. 9. The basic design features of this capsule are similar to those for the eight-ball capsule described in a later section of this report. Heat ratings of 70,000 to $150,000 \mathrm{Btu} / \mathrm{hr} \cdot \mathrm{lin} \mathrm{ft}$, depending on the capsule diameter, can be accommodated. Thermal- and fast-neutron fluxes, of $7 \times 10^{13}$ and $5 \times 10^{13}$ neutrons $/ \mathrm{cm}^{2} \cdot \mathrm{sec}$ respectively, are availablc.

For clad fuel element,s, application of the external collapsing forces to be experienced in gas-cooled reactor atmospheres has been provided by pressurizing the helium over the NaK surface. Pressures as high as 850 psi have been used. For temperature measurement in hollow cylindrical fuel pellets, molybdenum thermocouple wells brazed into the element end cap extend to the midplane elevation. Tungsten-rhenium thermocouples have been uced in thesc wells to measure $\mathrm{UO}_{2}$ fuel central temperatures 


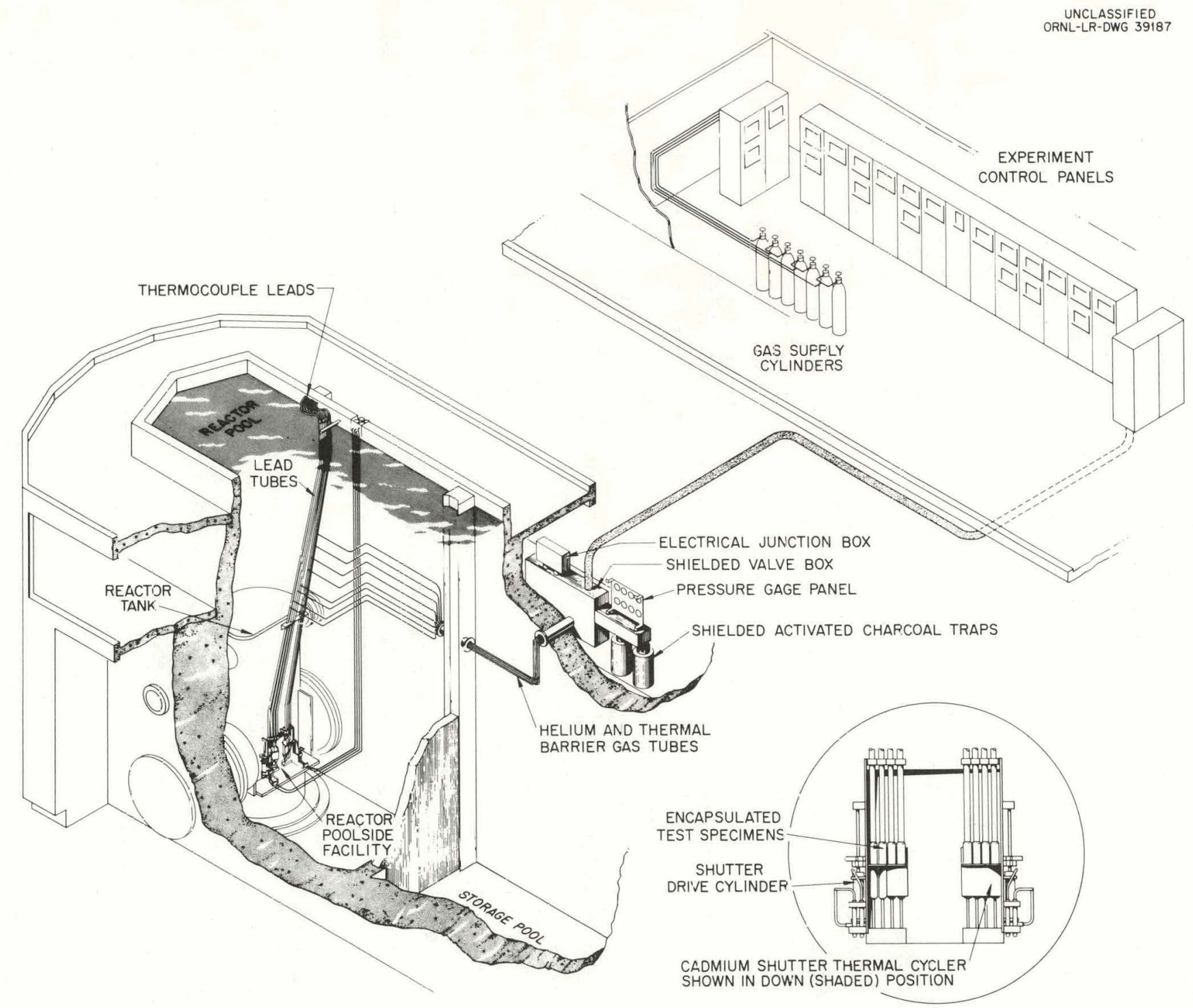

Fig. 7. Experimental Facilities for Irradiation of Full-Diameter Protosype Fuel Capsules in the ORR. 


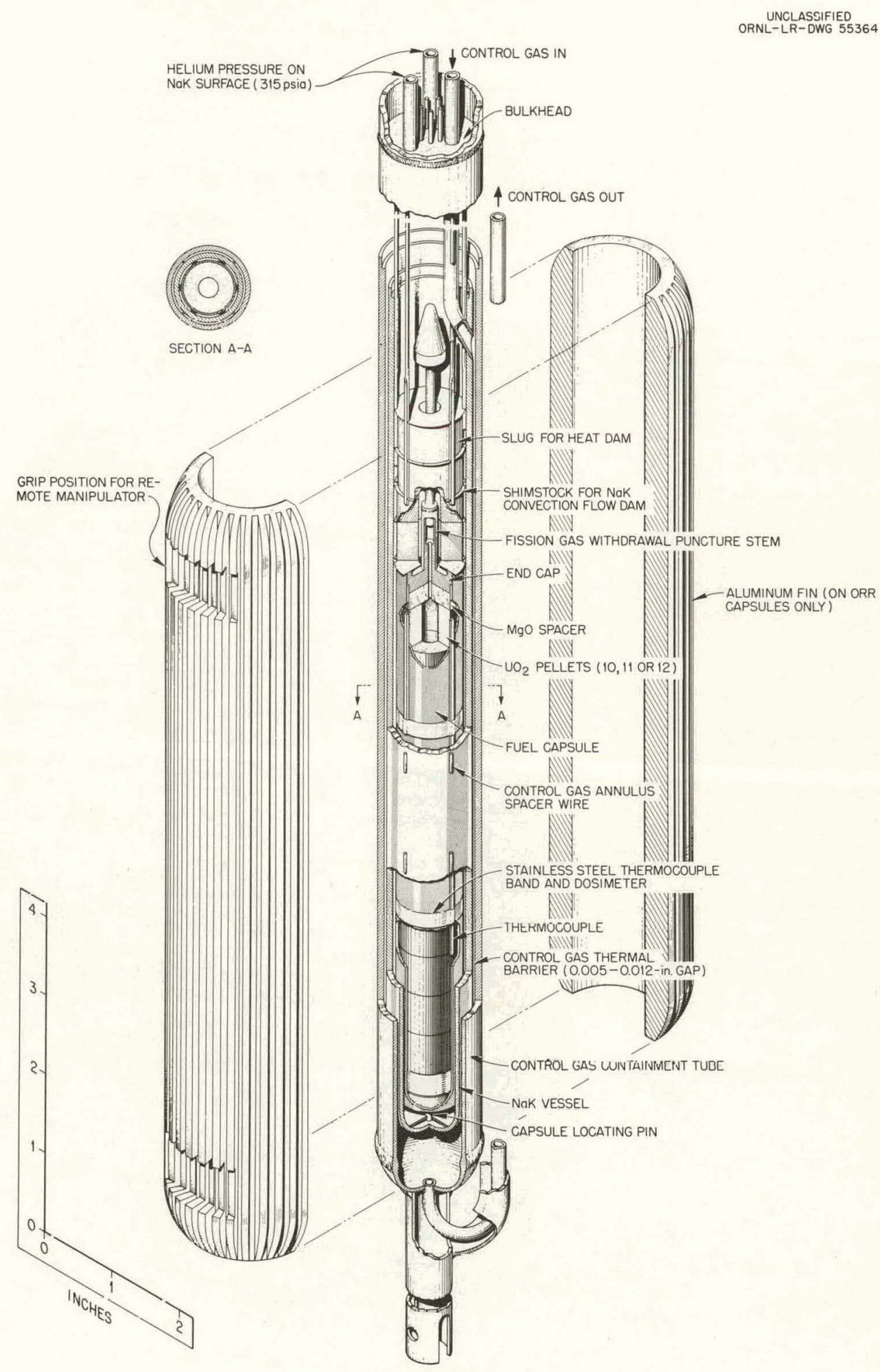

Fig. 8. EGCR Prototype Diameter Fuel Capsule for Irradiation in $\mathrm{ORR}$ and EIR. 


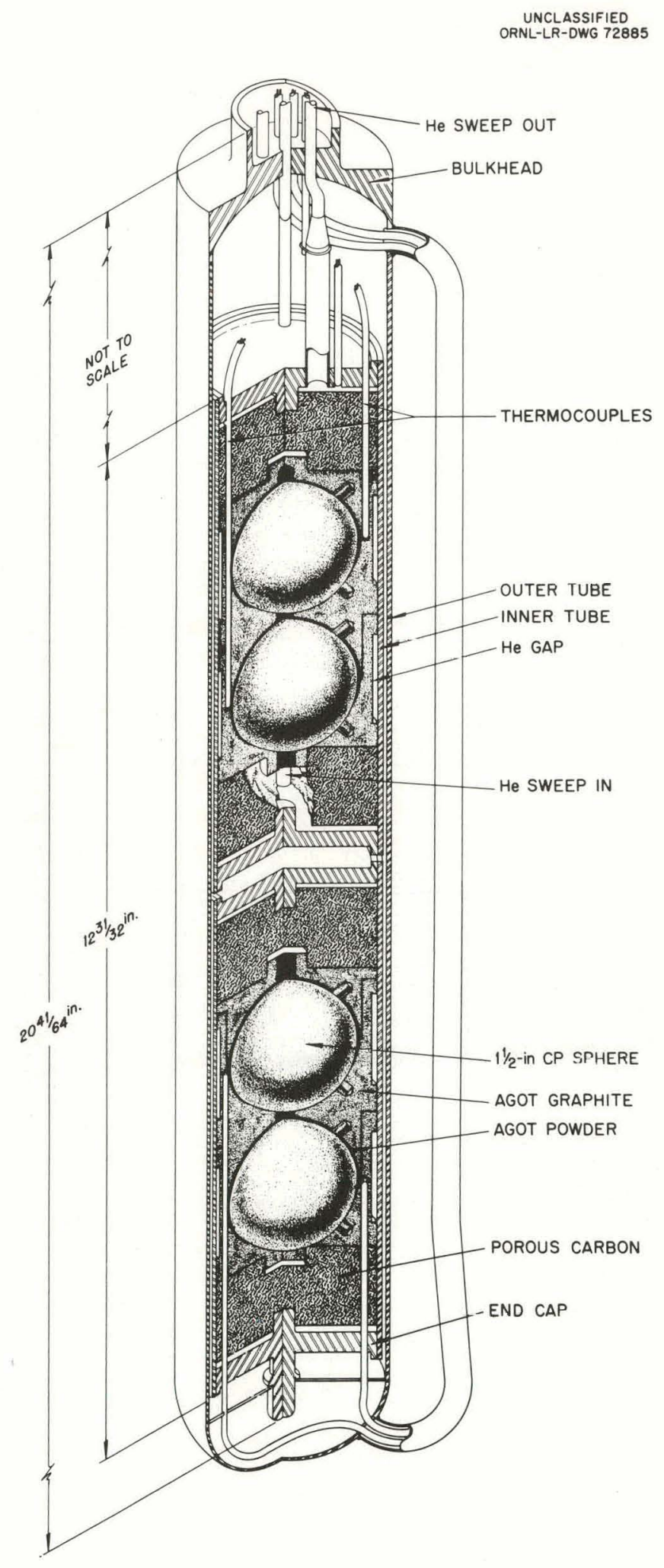

Fig. 9. Capsule for Irradiating Spherical Fuel Elements. 
up to $3700^{\circ} \mathrm{F}$. It is also possible to measure fuel central temperatures of graphite-matrix pellets and of fueled inserts within spheres at temperatures up to $2500^{\circ} \mathrm{F}$. Pressure transducers installed to measure the equilibrium pressure inside clad fuel elements during irradiation have functioned well, but the lifetimes have been limited, possibly by radiation damage to components.

Helium sweep-gas facilities have been provided for either continuous or intermittent determination of fission-gas release. A schematic flow diagram of the sweep capsule control and sampling system is shown in Fig. 10. Gas samples are removed for gamma-ray spectrometer analysis with the equipment shown in Fig. 1l. The ratios of gaseous fissionproduct-release rate to birth rate, $R / B$, measured to date have varied between $10^{-2}$ and $10^{-8}$ for different fuels. Daughter traps that use charged wires to collect solid decay products from noble gases in the sweep circuit, as shown in Fig. 12, provide a means for quantitative measurement of the short half-life noble gases.20

The thermal-neutron flux at each station in the irradiation facility can be monitored by argon activation, ${ }^{21}$ using the gamma-ray spectrometer for analysis. Movement of the capsules within the flux gradient of the facility can be accomplished during irradiation by means of a gear-driven mechanism operable from the pool surface using tools with extended handles. Manual control has been used with this equipment to maintain nearly constant flux during irradiation, as evidenced by temperature measurements; for example, capsules operated at $1600^{\circ} \mathrm{F}$ have been held within $\pm 30^{\circ} \mathrm{F}$ for extended periods.

The test systems described in Table 2 and shown as irradiated in the ORR, except the last one, were tested in this poolside facility. Fiftysix capsules have been irradiated since April 1958. No leakage of fission gases to the reactor room or failure of primary components, except instrumentation, has occurred. The facility has been utilized principally for Gas-Cooled Reactor Program irradiations, but it has flexibility to provide useful test information for many reactor programs. Additional drawings and photographs describing the equipment used are presented in Figs. 13 throigh $1 \%$

\section{ETR NaK-Cooled Capsules}

Equipment installed in the EIR was designed to accommodate 14 capsules simultaneously for comparison of proposed fuel pellets having different configurations for use in the EGCR. ${ }^{14}$ The irradiations programmed for these units involved lury test pcriods of up to three and four years, so revisions in equipment have not been necessary, and the present capability is essentially that for EGCR capsules. Very little modification would be necessary to accommodate other capsules; for example, the eightball capsule (see next section) could be accommodated by preparation of a new reactor core piece and revision of the lead tubes. By redesign 
Table 2. Gas-Cooled Reactor Program Capsule Irradiation Tests, July 1958 Through September 1963

\begin{tabular}{|c|c|c|c|c|c|}
\hline \multirow{2}{*}{$\begin{array}{l}\text { Reactor } \\
\text { Application }\end{array}$} & \multirow{2}{*}{$\begin{array}{l}\text { Test } \\
\text { Reactor }\end{array}$} & \multirow{2}{*}{ Test Item } & \multicolumn{2}{|c|}{$\begin{array}{l}\text { Cladding Test } \\
\text { Condition }\end{array}$} & \multirow{2}{*}{$\begin{array}{l}\text { Number } \\
\text { of } \\
\text { Tests }\end{array}$} \\
\hline & & & $\begin{array}{l}\text { Temperature } \\
\qquad\left({ }^{\circ} \mathrm{F}\right)\end{array}$ & $\begin{array}{l}\text { Pressure } \\
\text { (psia) }\end{array}$ & \\
\hline EGCR & ETR, ORR & $\begin{array}{l}\text { Short, prototype-diameter, stainless } \\
\text { steel-clad, } \mathrm{UO}_{2} \text { elements }\end{array}$ & $\begin{array}{l}1500 \\
1300\end{array}$ & $\begin{array}{l}300 \\
300\end{array}$ & $\begin{array}{l}18 \\
15\end{array}$ \\
\hline FGCR & ORR & $\begin{array}{l}\text { Short, BGCR prototype, instrumented } \\
\text { fuel assembly }\end{array}$ & 1500 & 300 & 7 \\
\hline EGCR & $\mathrm{ORR}$ & Vendor fuel for EGCR & 1500 & 300 & 5 \\
\hline EGCR & ORR & Vendor fuel for EGCR & 1300 & 300 & 1 \\
\hline EGCR & $\operatorname{LITR}^{a}$ & $\begin{array}{l}\text { Miniaturized pellets; fission-ga.s-re- } \\
\text { lease tests }\end{array}$ & 1300 & & 27 \\
\hline ECCCR & $\operatorname{LITR}^{a}$ & Capsule instrumentation development & 1300 & & 1 \\
\hline AGCR & $\operatorname{IITR}^{\mathrm{a}}$ & $\mathrm{BeO}-\mathrm{UO}_{2}-\mathrm{ThO}_{2}$ & 1300 & & 2 \\
\hline AGCR & $\operatorname{LITR}^{a}$ & $\mathrm{BeO}-\mathrm{UO}_{2}$ & 1300 & & 3 \\
\hline AGCR & $\operatorname{IITR}^{\mathrm{a}}$ & High-temperature $\mathrm{UO}_{2}$ & $4000^{b}$ & & 4 \\
\hline AGCR-AGR & ORR & Be-clad $\mathrm{UO}_{2}$ (two capsules by UKAFA) & 1100 & 300 & 3 \\
\hline AGCR-EL4 & $\mathrm{ORR}$ & Be-clad $\mathrm{UO}_{2}$ (four capsules by CEA) & 1100 & $\begin{array}{l}300,450 \\
\text { and } 725\end{array}$ & 5 \\
\hline$\Lambda G C R-E L 4$ & $\mathrm{ORR}$ & $\begin{array}{l}\text { Thin, stainless steel-clad } \mathrm{UO}_{2} \text { (cap- } \\
\text { sules by CEA) }\end{array}$ & 1200 & 850 & 2 \\
\hline AGCR & $\mathrm{ORR}$ & Swaged stainless steel-clad $\mathrm{UO}_{2}$ & 1300 & 300 & 3 \\
\hline AGCR & ORR & Tamp-packed $\mathrm{UO}_{2}$ in stainless steel & 1300 & 300 & 1 \\
\hline AGCR & ORR & $\begin{array}{l}\text { Vibratory-packed } \mathrm{UO}_{2}-\mathrm{ThO}_{2} \text { in stainless } \\
\text { steel }\end{array}$ & $\begin{array}{l}1000 \text { and } \\
1300\end{array}$ & 300 & 2 \\
\hline AGCR & $\mathrm{ORR}^{\mathrm{C}}$ & $\mathrm{BeO}-\mathrm{UO}_{2}$ & $2100^{\mathrm{b}}$ & & 1 \\
\hline $\begin{array}{l}\text { Fueled graph- } \\
\text { ite }\end{array}$ & $\mathrm{ORR}^{\mathrm{c}}$ & $\begin{array}{l}\text { Pyrolytic-carbon-coated } \mathrm{UC}_{2} \text { particles } \\
\text { in graphite matrix }\end{array}$ & $\begin{array}{l}1700 \text { and } \\
2400^{b}\end{array}$ & & 3 \\
\hline $\begin{array}{l}\text { Fueled graph- } \\
\text { ite }\end{array}$ & $\operatorname{LITR}^{a}$ & Pyrolytic-carbon-coated IJ_; particles & 1300 & & 7 \\
\hline $\begin{array}{l}\text { Fueled graph- } \\
\text { ite }\end{array}$ & $\operatorname{LITR}^{\mathrm{a}}$ & UC fuel & 1300 & & 3 \\
\hline $\begin{array}{l}\text { Fueled graph- } \\
\text { ite }\end{array}$ & $\mathrm{ORR}^{\mathrm{c}, \mathrm{d}}$ & $\begin{array}{l}\text { Pyrolytic-carbun-coated } \mathrm{UC}_{2} \text { particles } \\
\text { in graphite sphere }\end{array}$ & 1500 & & 1 \\
\hline $\begin{array}{l}\text { Fueled graph- } \\
\text { ite }\end{array}$ & $\mathrm{ORR}^{\mathrm{c}, \mathrm{d}}$ & Fueled matrix insert in graphite sphere & 1200 & & 1 \\
\hline $\begin{array}{l}\text { Fueled graph- } \\
\text { ite }\end{array}$ & $\mathrm{ORR}^{\mathrm{c}}$ & $\begin{array}{l}\text { Pyrolytic-carbon-coated } \mathrm{UC}_{2} \text { particles } \\
\text { in } 6-\mathrm{cm} \text {-diam graphite sphere with a } \\
\text { molded shell }\end{array}$ & 1600 & & 3 \\
\hline $\begin{array}{l}\text { Fueled graph- } \\
\text { ite }\end{array}$ & ORR & $\begin{array}{l}\text { Eight-ball test of manufacturing vari- } \\
\text { ables and mechanical stability }\end{array}$ & 1500 & & 2 \\
\hline
\end{tabular}


(20in)

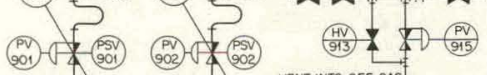

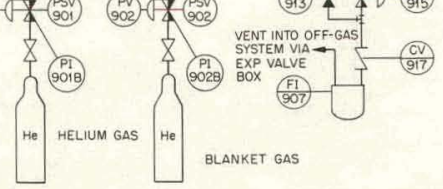

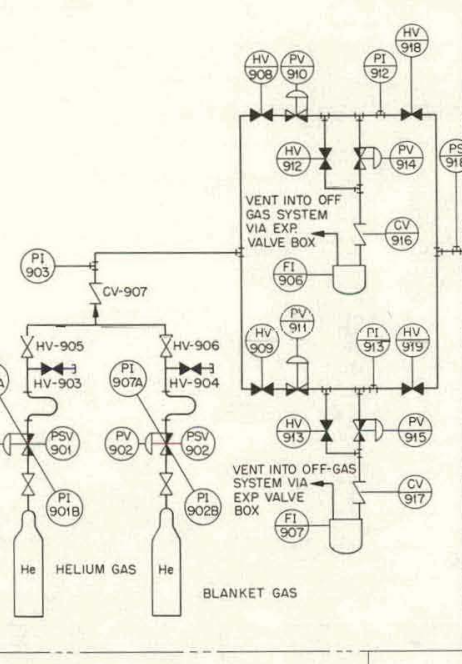

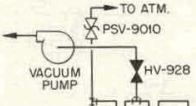

(8.) (ल) HV-5008 1

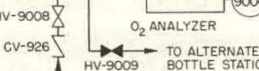

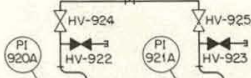

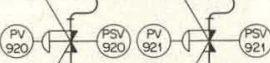

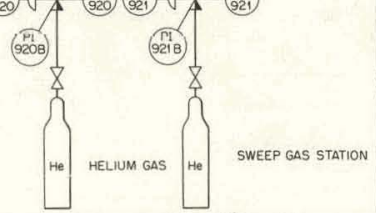

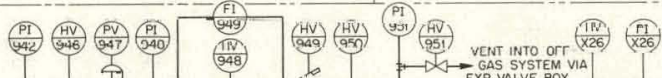

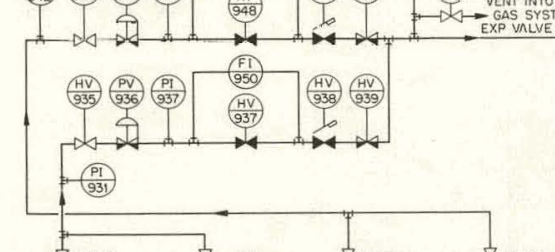

(2029)

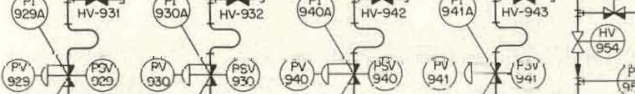
(192) (20)

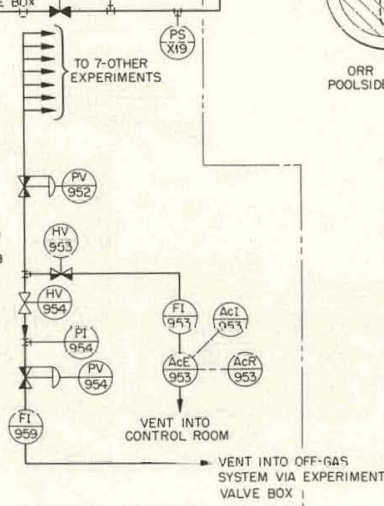

Fig. 10. ORR Poolside Capsule Ga.s Control and Sampling Systems for Fuel Irradiations. 


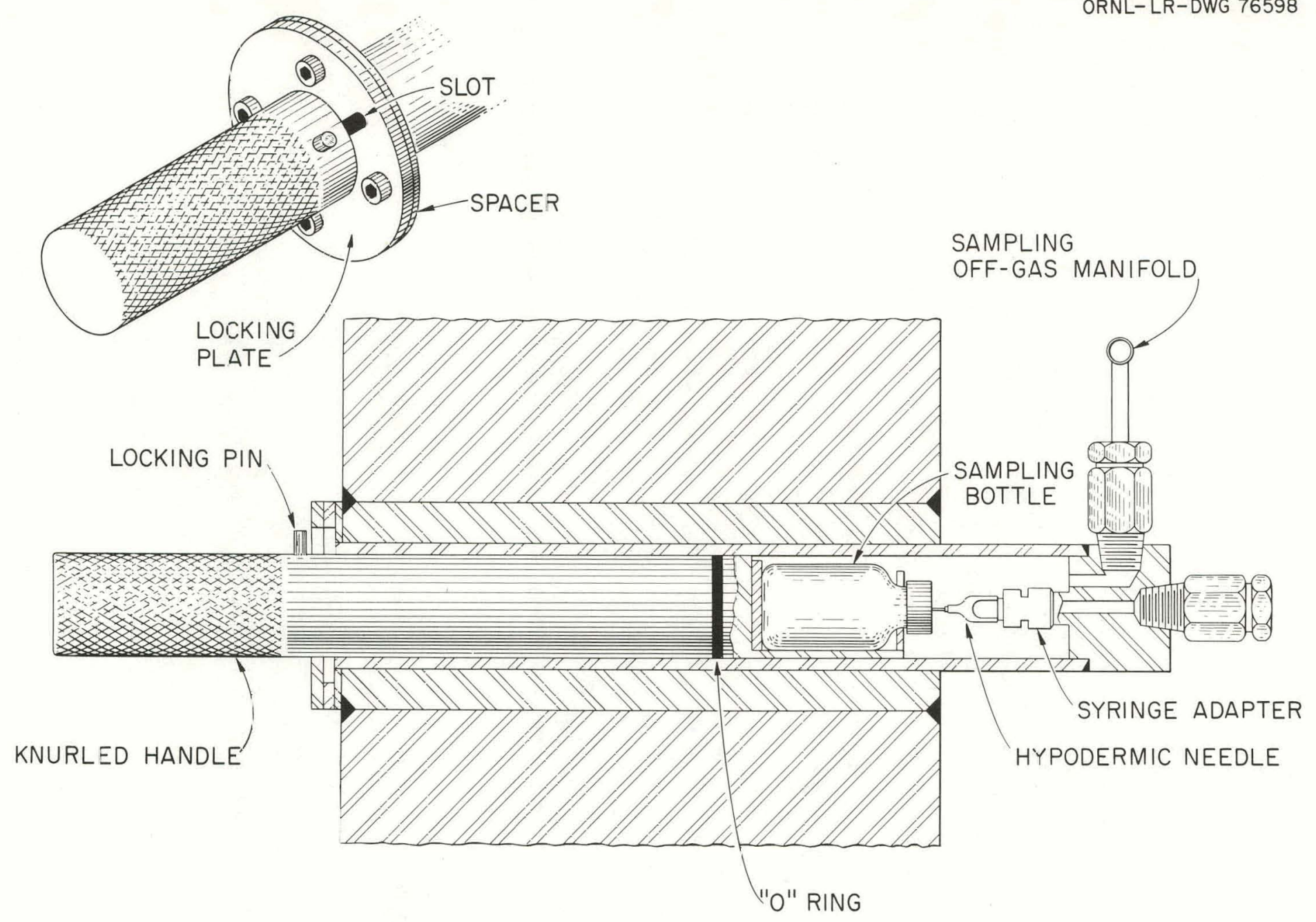

Fig. 1l. Sweep Capsule Sampling Station. 


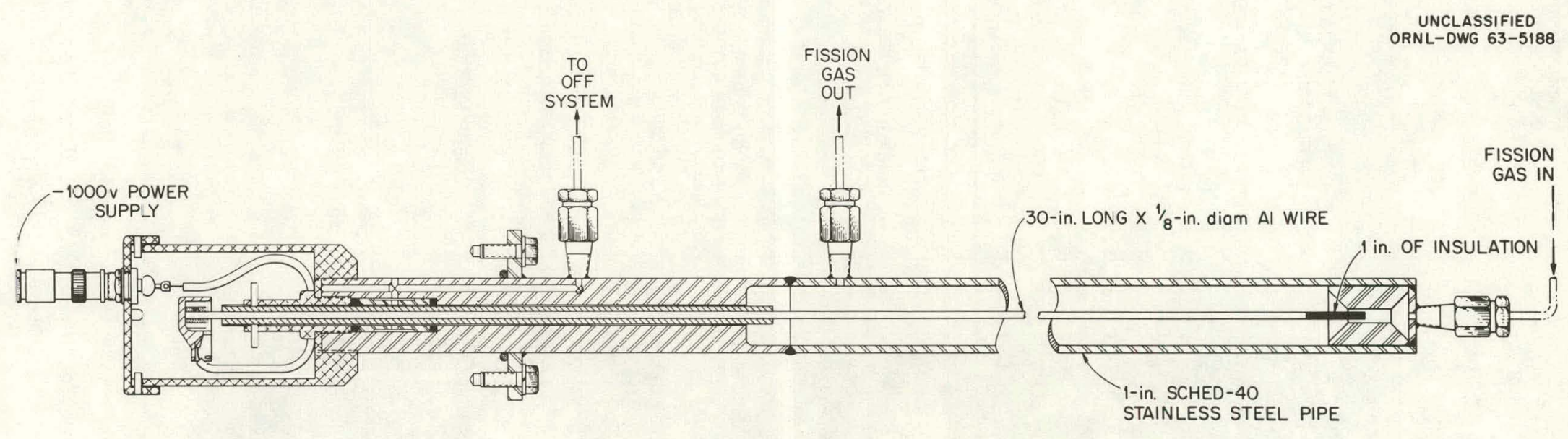

Fig. 12. Daughter-Trap Sampling Wire and Housing for ORR Poolside Capsules. 


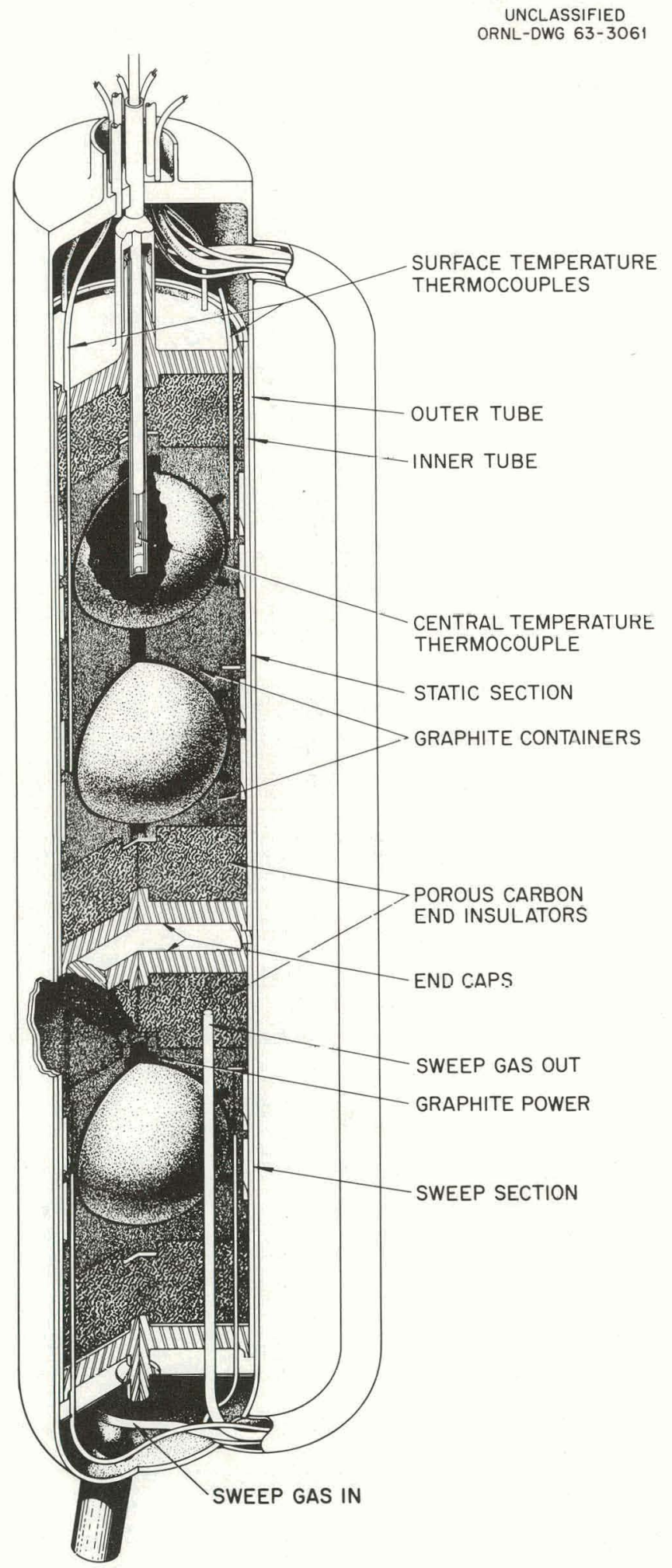

Fig. 13. Sweep Capsule Assembly for Irradiation of 6-cm-diam Spherical Fuel Elements in the ORR Poolside Facility. 


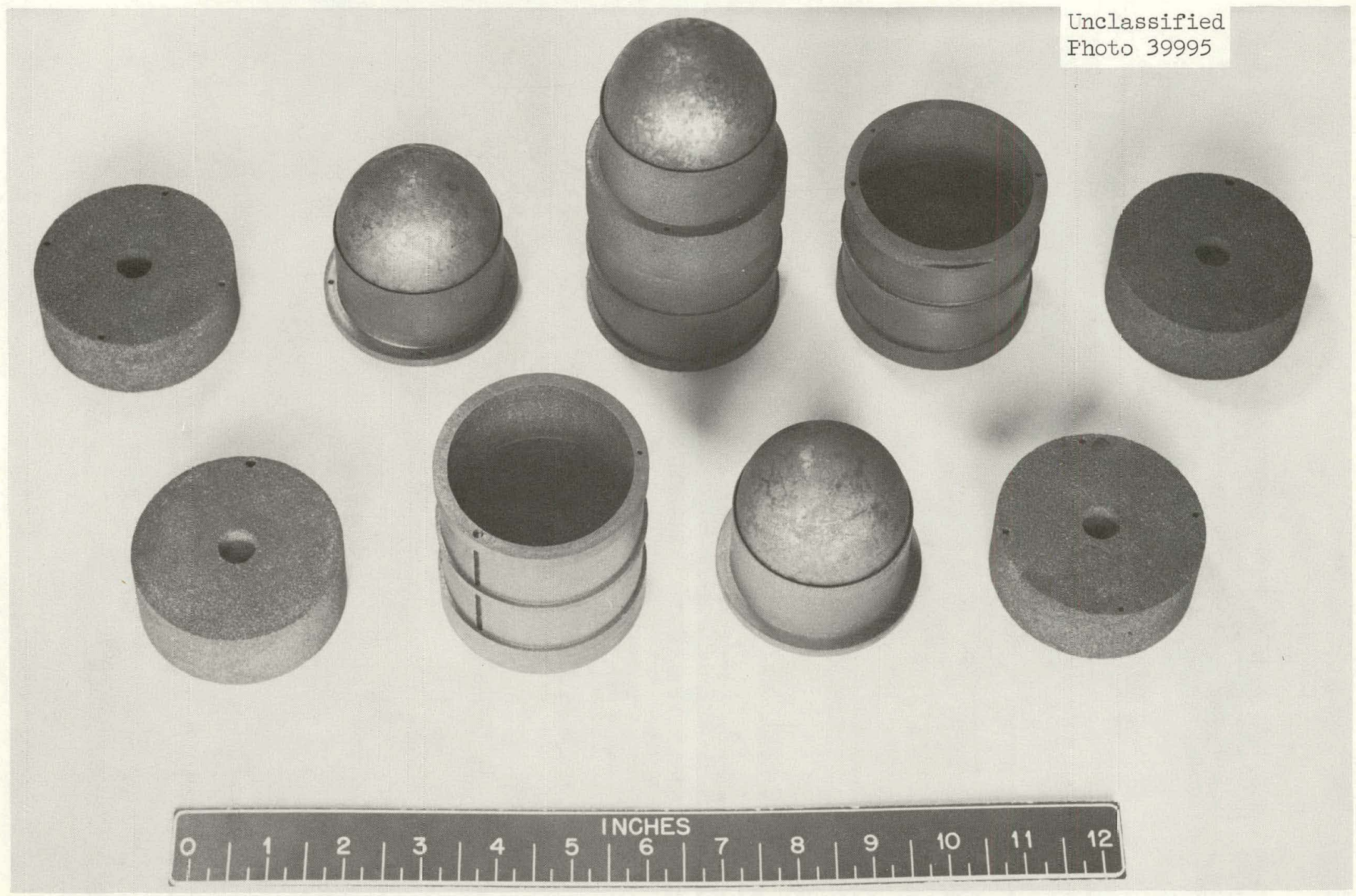

Fig. 14. Graphite Parts and Fueled Spheres for ORR Poolside Capsule. 


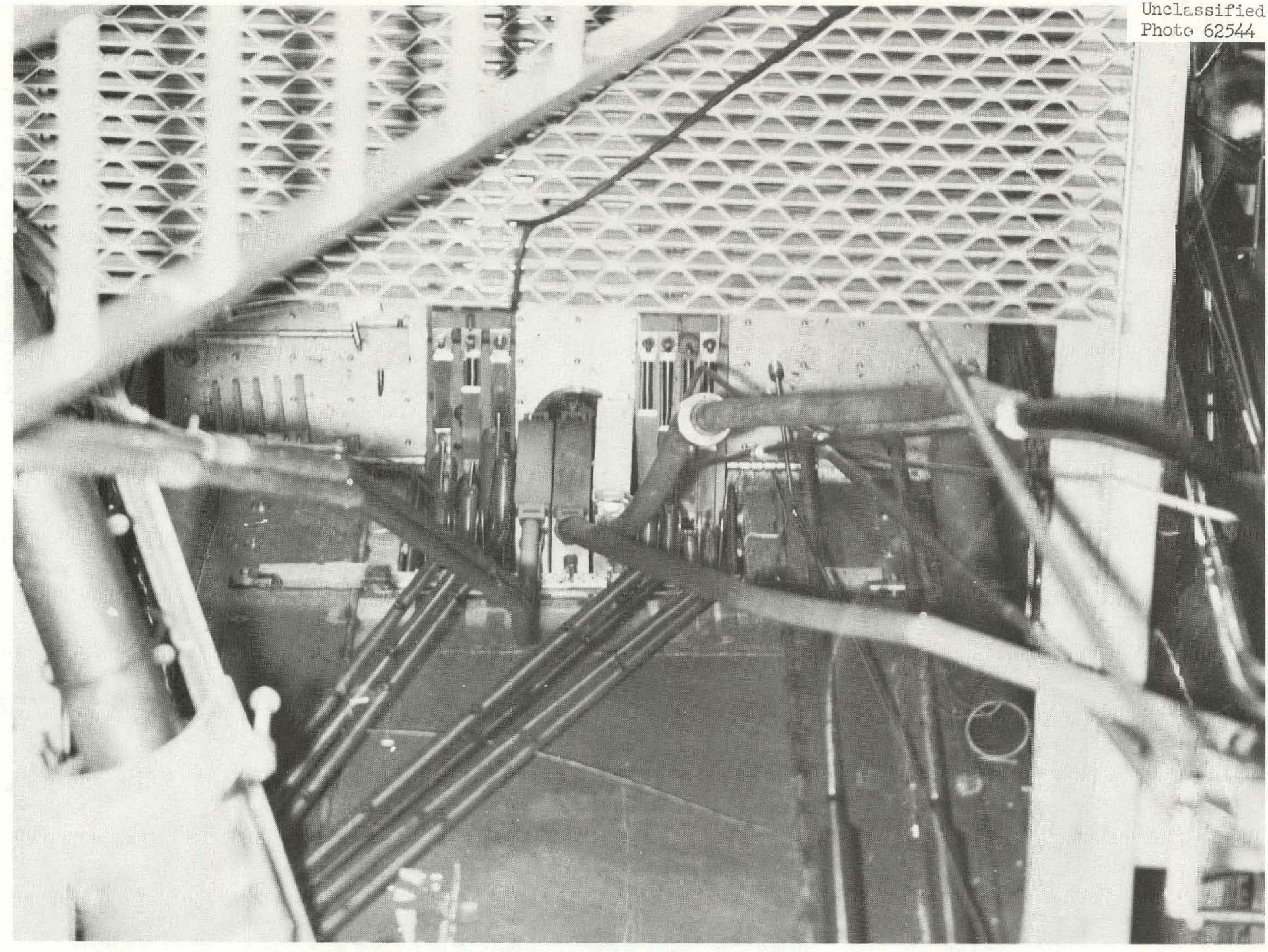

Fig. 15. Closeup Underwater View of ORR Poolside Capsules. Three rectangular boxes at center are for other experiments. 


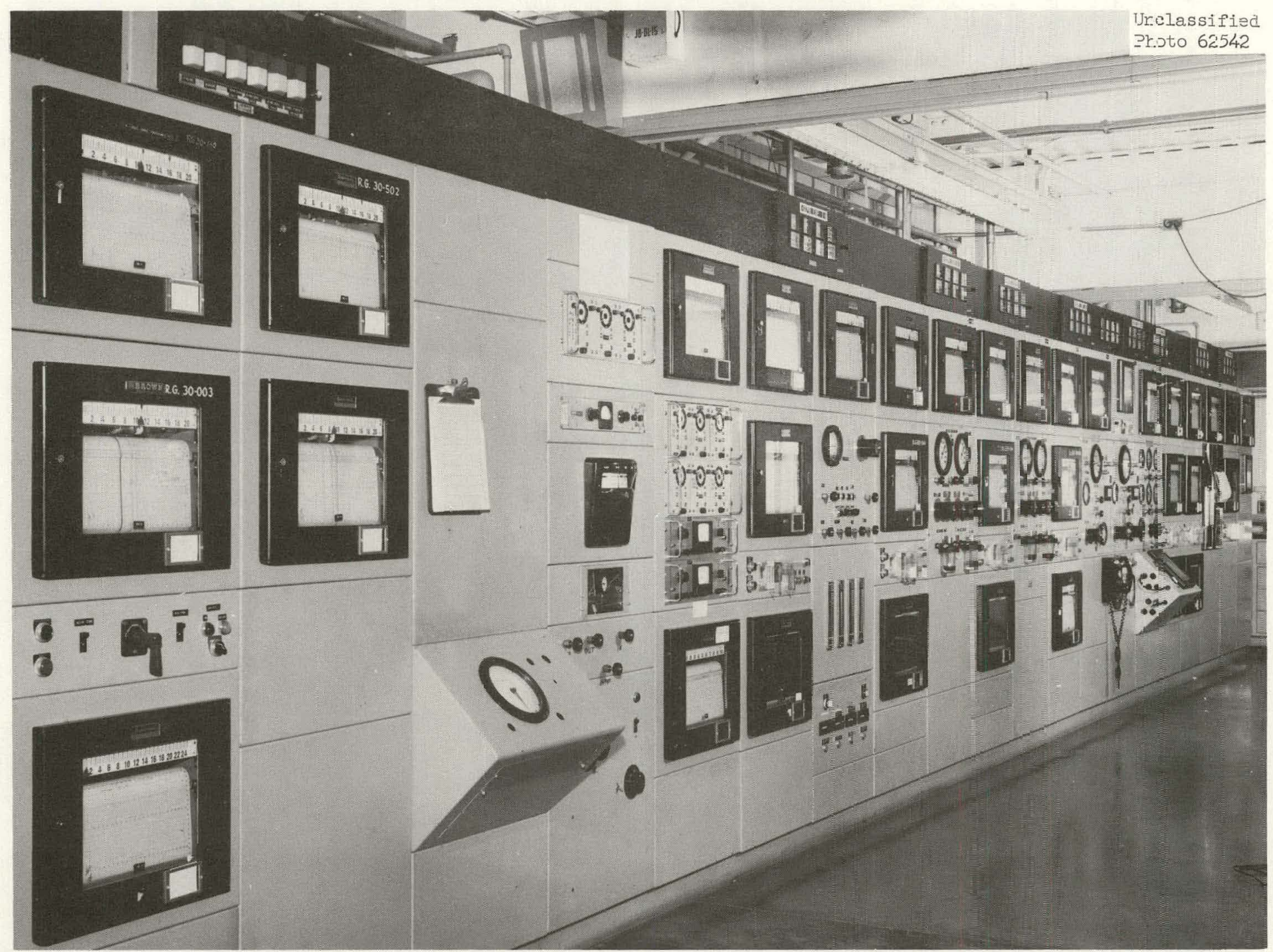

Fig. 16. Instrument Control Panel for ORR Poclside and Eight-Ball Experiments. 


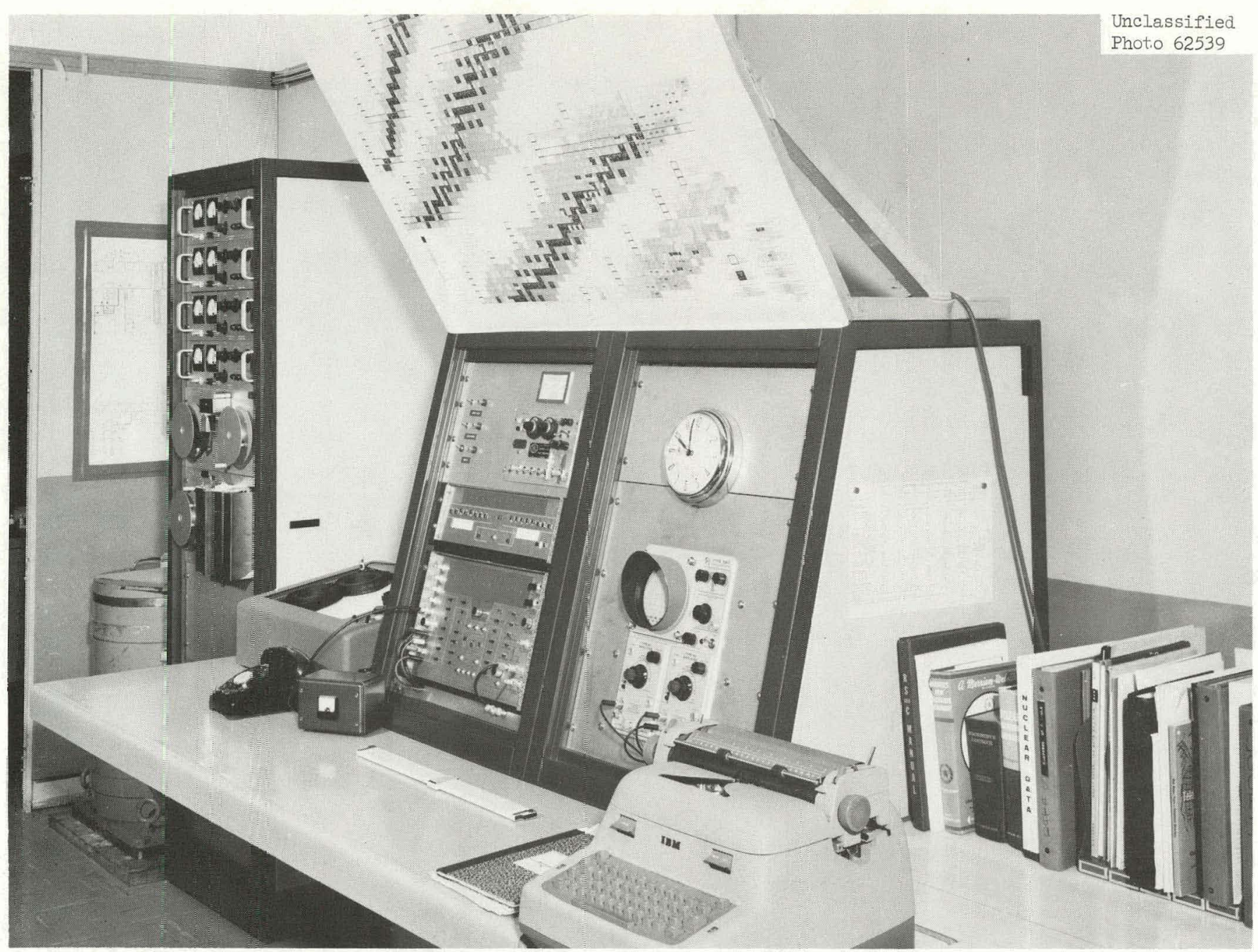

Fig. 17. Gamma-Ray Spectrometer for Loop and Capsule Experiments. Installation for analysis of fission products, argon activation, and corrosion produzts as applicable to ORR poolside and eight-ball capsules, ORR loop No. 1, ORR loop No. 2, and pressurized-water loop. 
for the use of core positions instead of the reflector locations now occupied, the high fluxes for both fast and thermal neutrons of the EIR could be utilized. In particular, tests of sodium-cooled or gas-cooled fast-reactor fuels could be accomplished with very little alteration.

The capsule used is shown in Fig. 8, and the tests conducted at the EIR are listed in Tables 1 and 2. Work on the EIR capsules for the EGCR irradiation program was conducted jointly with the Phillips Petroleum Company. 22

\section{ORR Eight-Ball Capsule}

A capsule was needed in which several spherical graphite elements containing coated-particle fuels could be irradiated simultaneously under similar conditions for comparative evaluation. The fabrication variables to be studied included (1) methods for preparing fuel particles and their coatings and (2) the type of graphite $\mathrm{mix}$ and techniques used in forming matrices and unfueled shells, that is, blending procedures, molding processes, heating rates, final treatment temperatures, and impregnation processes. A relatively high fast-neutron flux was desired to accumulate radiation damage in the graphite comparable to that expected for the fuel lifetime in a power reactor. Important considerations in design were measurement of temperature and simplicity in construction to minimize cost.

The capsule is located in core position F-I of the ORR, which has the advantages of a relatively high fast-neutron flux, $1.3 \times 10^{14}$ neutrons $/ \mathrm{cm}^{2}$.sec, a uniform thermal flux over a considerable vertical length (peak value, $1.5 \times 10^{14}$ neutrons $/ \mathrm{cm}^{2} \cdot \mathrm{sec}$ ), and adequate cooling capacity for the spherical elements in a compact arrangement. The facility affords sufficient space to accommodate 1 1/2-in.-diam fuel elements. Based. on this diameter and the ORR vertical flux profile, it was determined that suitable irradiation conditions could be achieved for eight spheres henre, the titile eight,-ha.7.1.

The basic configuration chosen for the experimental assembly is shown in Figs. 18 and 19. The graphite parts are carefully machined and close fitting. Small spheroidal coke particles are used in a loose bed to enhance the heat transfer from the fuel spheres to the graphite structure without restraint on the surfaces of the spheres. The fuel spheres are centered in the cavities by small pins inserted in the graphite. Temperatures are measured by thermocouples inserted in the graphite structure and, when appropriate, inside the fuel spheres. A thermocouple can be installed conveniently in the top fuel sphere. Although the capsule was designed for spherical fuel elements, it could easily be redesigned for other configurations.

The gas gap between the graphite sleeve and the inner wall of the primary stainless steel containment vessel determines the operating 


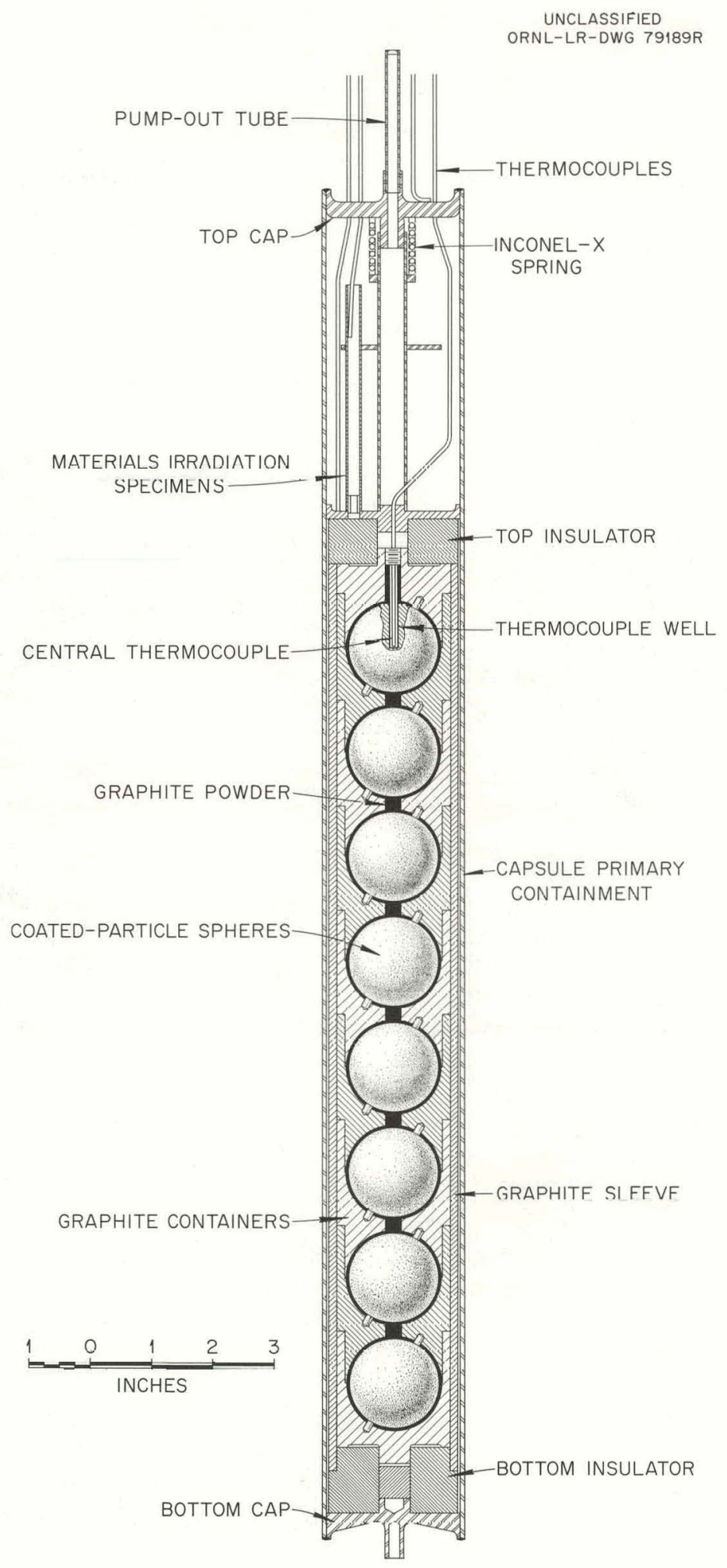

Fig. 18. ORR Eight-Ball Assembly Showing Fueled Spheres Assembled. in a Graphite Structure. Secondary outer containment is not shown. 


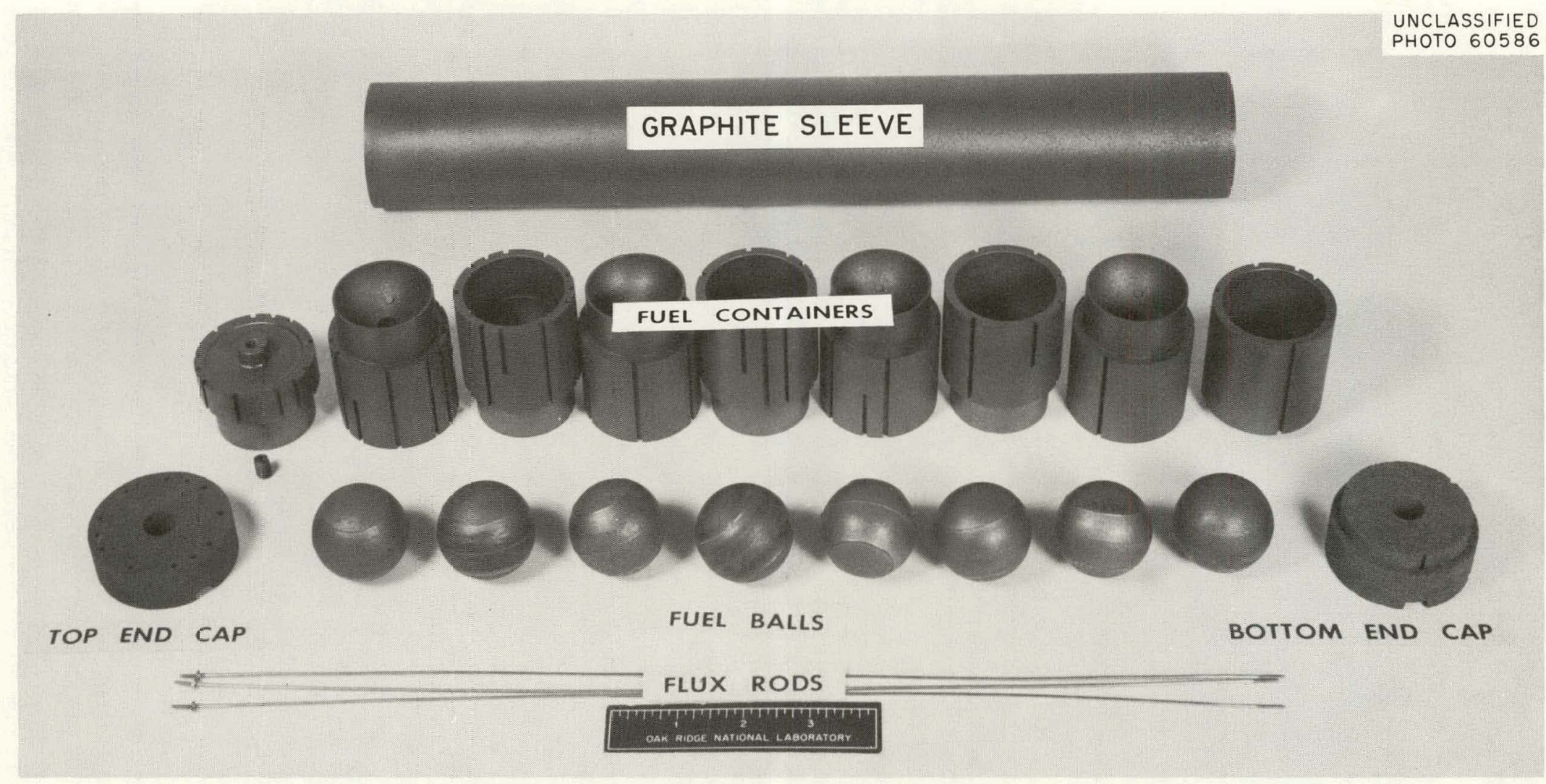

Fig. 19. Eight-Ball Capsule Parts. 
temperatures of the graphite and the fuel relative to the primary containment structure. A second gas gap between the primary container and a secondary stainless steel container (not shown in Fig. 18 but arranged. similarly to the configuration of the four-ball capsule shown in Fig. 9) was dimensioned to produce a temperature difference of several hundred degrees Fahrenheit when filled with a helium-nitrogen mixture. The gas mixture is varied to provide temperature control.

The experiments are operated from ORR poolside capsule instrument panel position No. 7 and share the same shielded valve-control box, sampling station, and gas supply, as shown in the schematic diagram of Fig. 10; thus all variables achievable in the poolside facility, except neutron flux adjustment, are available. The sharing of facilities provides the advantage of economical operation for this experiment, since very little additional operator coverage is required.

The overall performance of the capsule has been quite satisfactory. Temperatures in the graphite at the midplanes of fuel spheres have varied no more than $\pm 50^{\circ} \mathrm{F}$, with an approximately symmetrical pattern about the vertical center. The experiments that have been conducted in this facility are listed in Table 2 .

\section{IITR Air-Cooled Capsules}

The equipment for LITR irradiations utilizes forced-air cooling of the capsule.14,15 Two of the designs employed are shown in Fig. 20. One assembly accommodates a small specimen of solid fuel, such as $\mathrm{UO}_{2}$, UC, or UN, which may be surrounded by a ceramic insulating sleeve to obtain higher temperatures, as shown in the parts display of Fig. 2l. A third. design provides small cans of noble or refractory metal to contain coated particle or granular fuels ${ }^{23}$ (shown in Fig. 22). A gas annulus between the fuel or its container and the outer wall of the capsule permits operation at considerably higher temperatures than are possible for the capsule container. Two or more separately enclosed fuel containers can be accommodated in each half of the capsule. Containers made of graphite or of ceramics can be used where metals are not compatible with the fuels to be tested. The outer container for these capsules is designed only for convenience of the fuel irradiation, with no attempt to obtain information relative to encapsulation techniques. Figures 23 and 24, respectively, show the facility tube that directs the air flow over the capsules and a schematic diagram of the system and controls.

An important and common feature of most IITR capsule designs is the thermocouple for measuring the central temperature of the hollow fuel specimens. Tungsten vs rhenium or tungsten vs rhenium alloy thermocouples are normally employed with tantalum or a refractory metal sheath to prevent direct contact of the thermocouple junction with the fuel. Irradiations of $\mathrm{UO}_{2}$ have been conducted at temperatures giving an indicated output of $37 \mathrm{mv}$ with $\mathrm{W}-5 \%$ Re vs W-25\% Re thermocouples. The temperature 


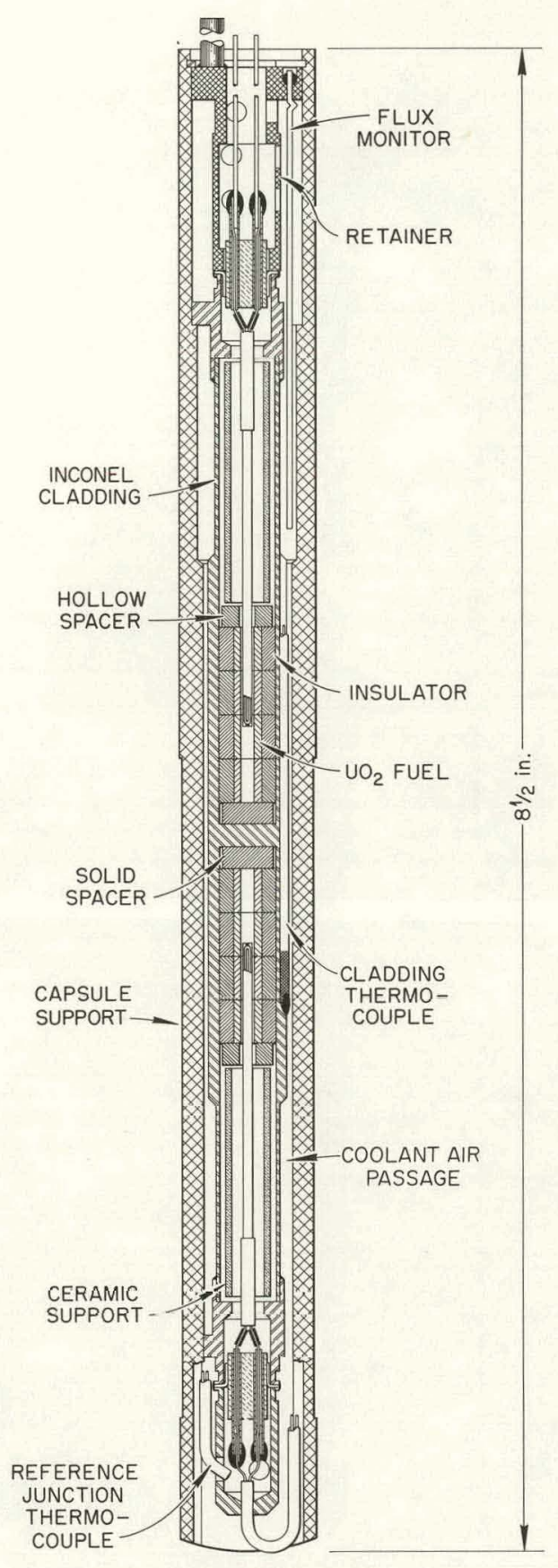

CERAMIC-INSULATED S.APSIII F

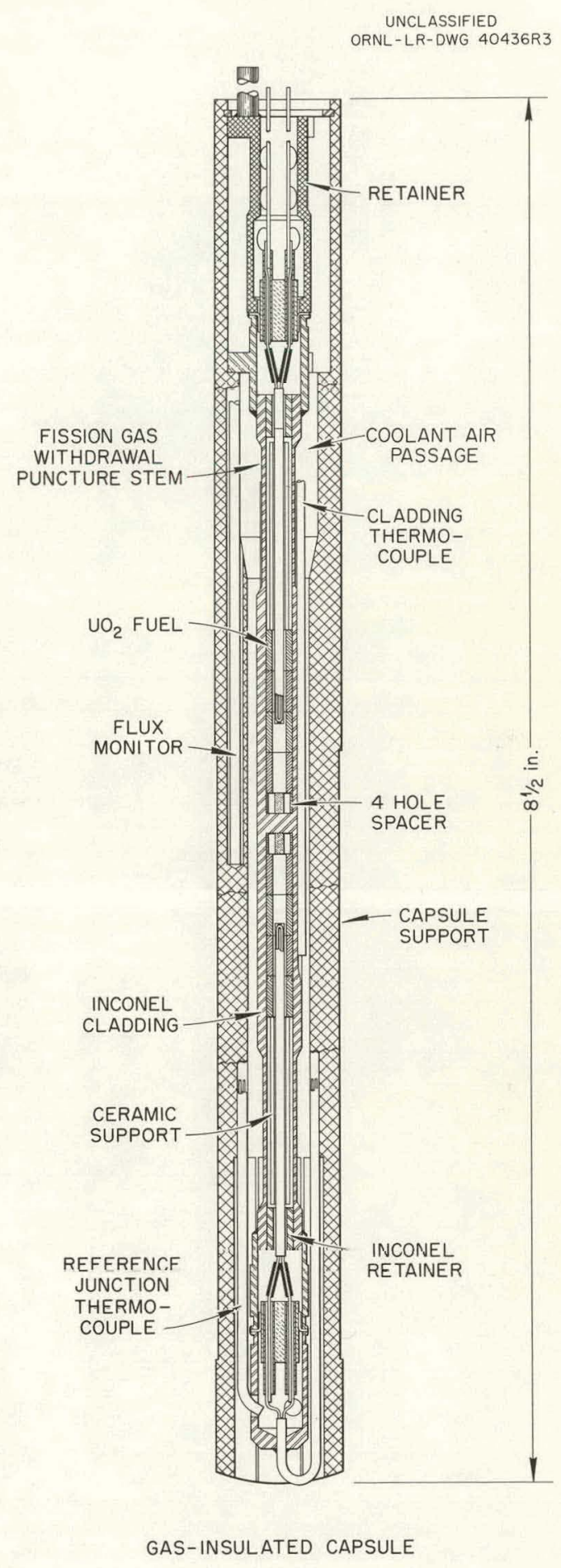

Fig. 20. IITR Capsule Parts. 


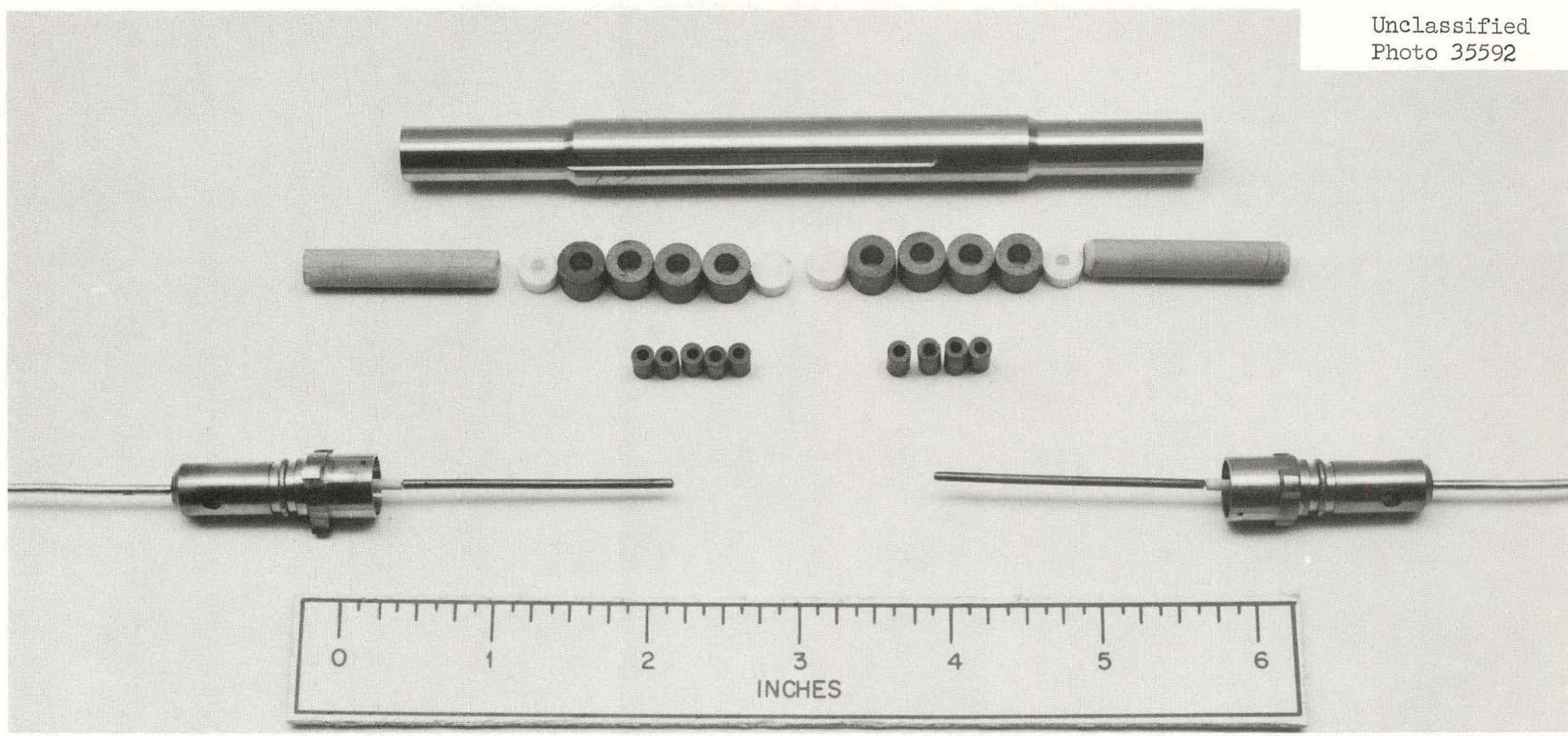

Fig. 21. LITR Capsule Parts Prior to Assembly. Thermocouples, hollow cylindrical fuel peliets, ceramic insulators, and the capsule container, respectively, are shown from bottom to top. 


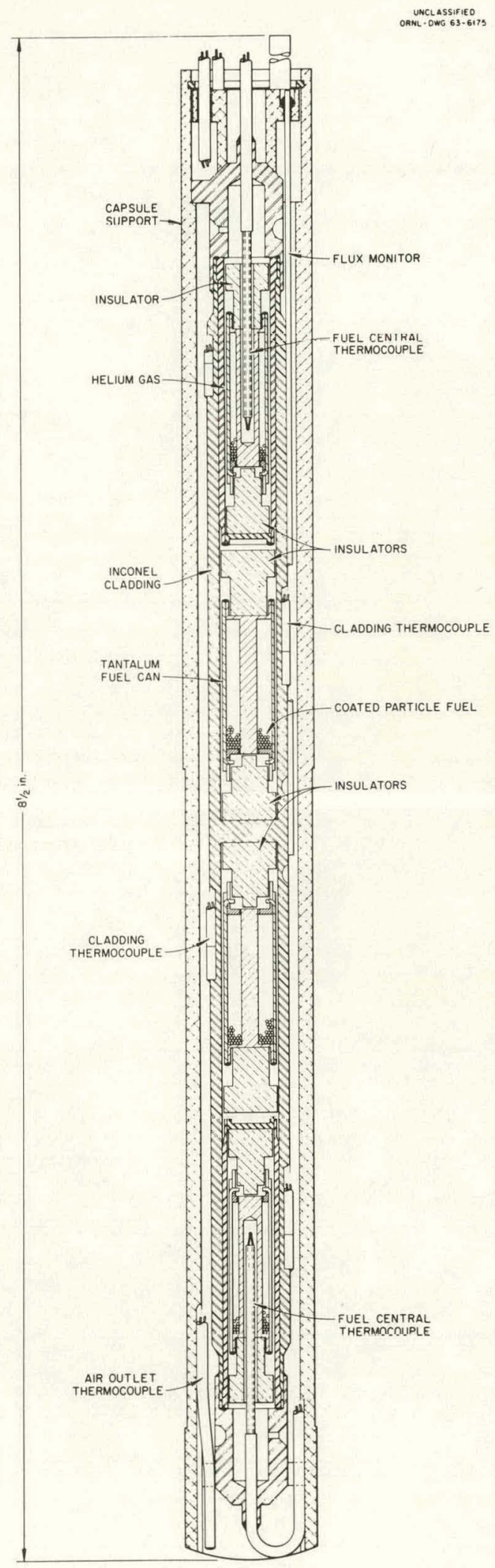

Fig. 22. IITR Capsule for Irradiating Coated Particle Fuel. 


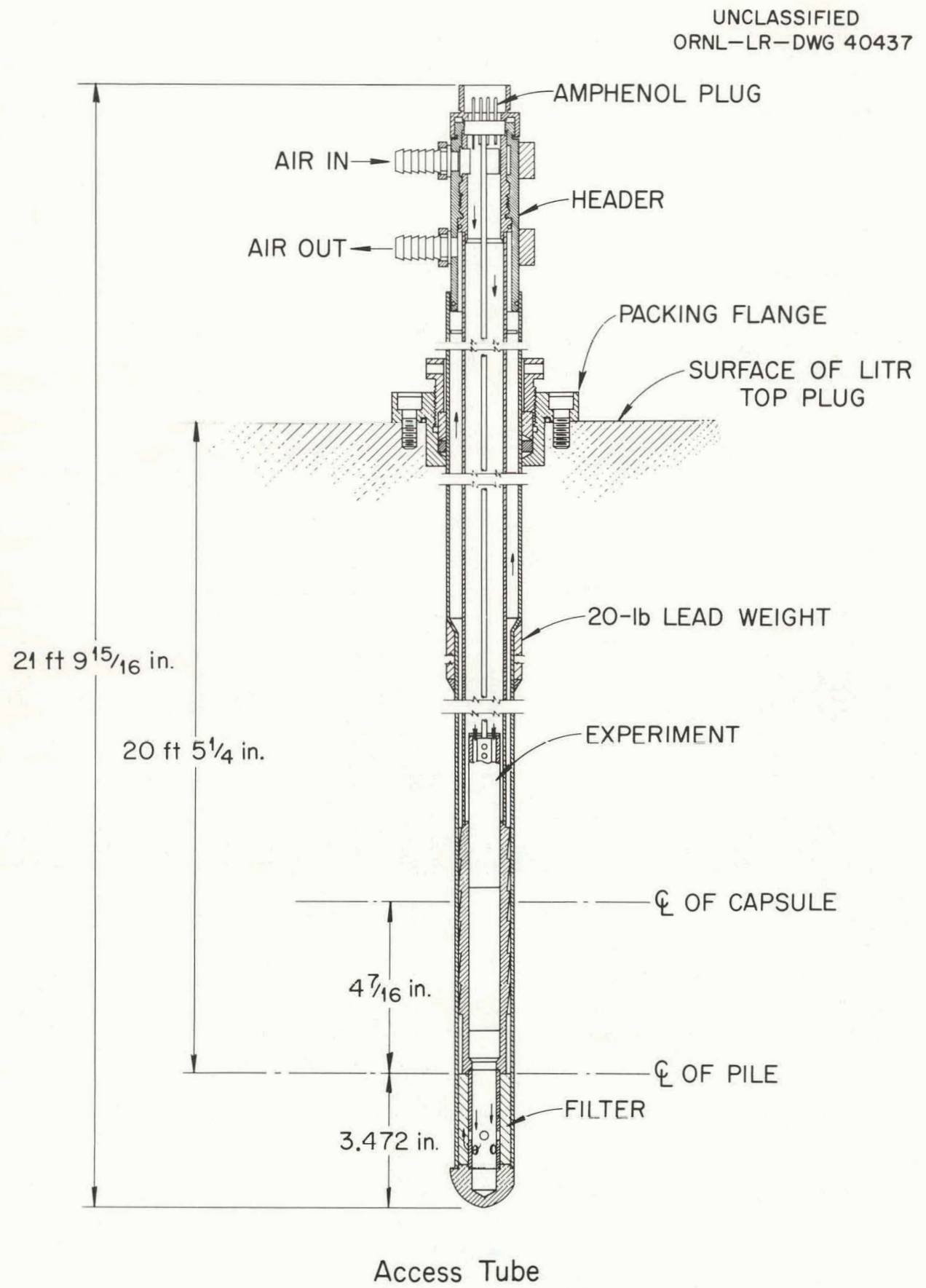

Fig. 23. LITR Capsule Access Tube to Direct Cooling Air Over Capsule and Isolate It from the Reactor. 


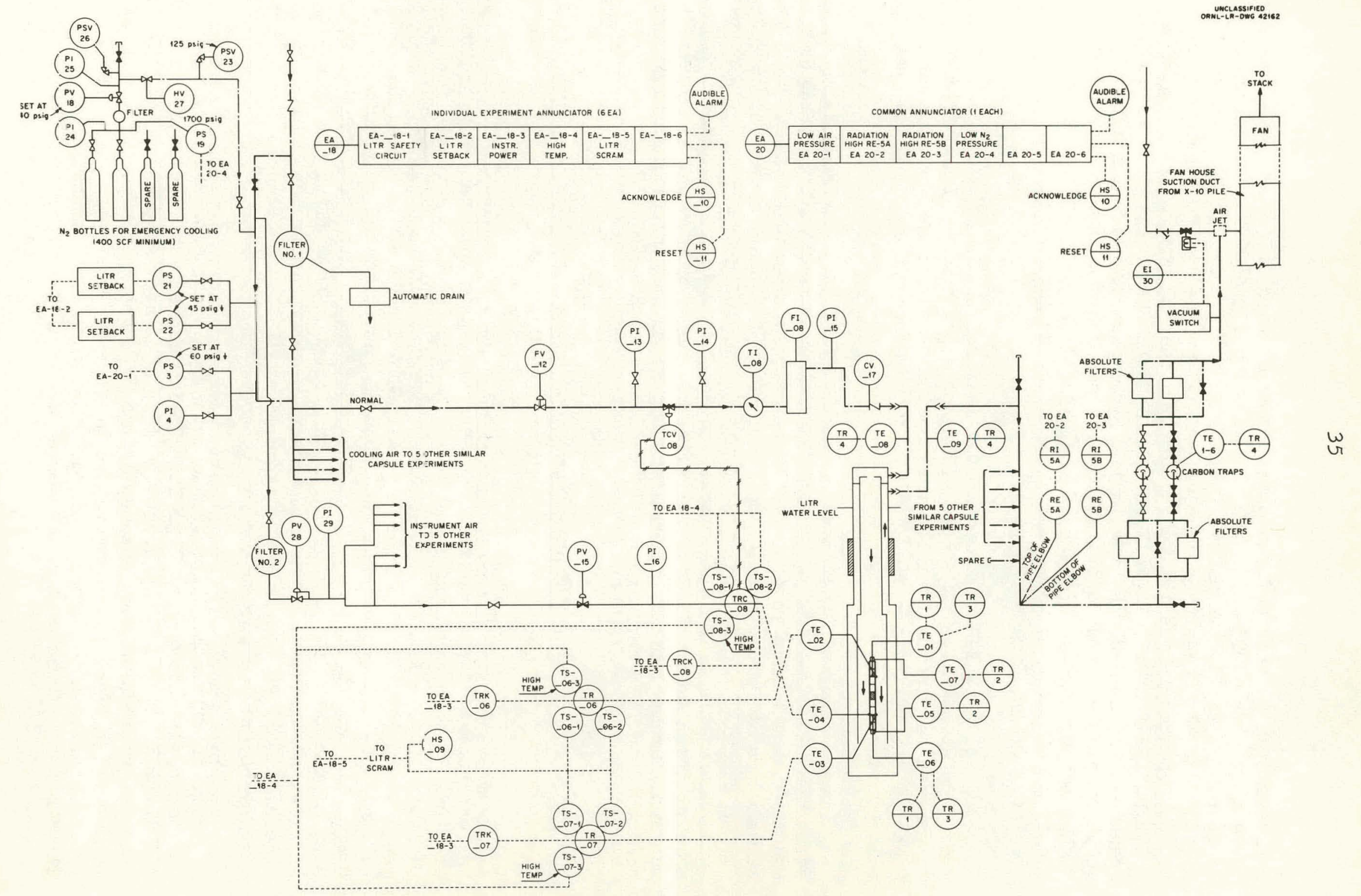

Fig. 24. Flow Diagram for LITR-GCR Experiments. 
corresponding to this emf, as obtained by extrapolation of a calibration curve above its $4200^{\circ} \mathrm{F}$ limit, 24 is approximately $4400^{\circ} \mathrm{F}$. At these temperatures, a rapid downward drift in emf occurs early in the irradiation period, but the cause cannot be determined precisely from these experiments. Changes in the fuel structure and thermal conductivity could be contributing factors, as well as thermocouple instability and insulation breakdown. Below $3200^{\circ} \mathrm{F}$, the indicated temperatures are consistently quite stable, and stable operation is also observed in some instances at higher temperatures. Closure of the capsule is achieved with a commercially available metal-to-ceramic hermetic insulating seal through which the thermocouple lead wires pass.

Control is based on temperatures measured on the lower capsule wall, which operates at the higher equilibrium temperature, and is effected by varying the air velocity and corresponding heat transfer coefficient. Measurements of the air flow and its temperature above and below the capsule provide for determination of the total power generation.

These capsules have the advantage of simplicity and economy in construction. The small size permits operation at very high power densities, and thus high burnup is achieved in relatively short exposure times. The capsule control is automatic and requires little operator attention. Seven double capsules can be operated simultaneously with equipment presently available at the LITR. The thermal-neutron flux in the assigned LITR core position (shown in Fig. 2) varies between $5 \times 10^{12}$ and $2 \times 10^{13}$ neutrons $/ \mathrm{cm}^{2} \cdot \mathrm{sec}$; other capabilities are given in Table 1 . Irradiations conducted in IITR capsules are listed in Table 2.

\section{ORR Gas-Cooled Loop No. 1}

Gas-cooled loop No. 1,25 which is equipped to recirculate helium gas, was designed to test clad fuel elements appropriate to the EGCR or similar reactors of more advanced concept.26 It also is quite suitable for tests of fuel elements for fast gas-cooled reactors. The overall capability of the loop is described in lable 3. Although designed for operation with helium, the loop can be used with several gas coolants. The principal components and their location in the ORR facility are shown in Fig. 25. Most of the loop is located within the ORR pool to utilize the shielding afforded by the water. The compressors, primary instrumentation, and some auxiliary equipment are located in a shielded cubicle on the lower balcony to provide access for maintenance.

The interrelationships of the main loop components are shown in the schematic flow diagram of Fig. 26. Helium coolant at flow rates up to $400 \mathrm{lb} / \mathrm{hr}$ is circulated through the loop at a nominal pressure of 300 psia by two turbine compressors, of the type shown in Fig. 27, piped in series. A typical loop temperature profile for operation with a fuel element having a heat rating of $35,000 \mathrm{Btu} / \mathrm{hr}$. ft is shown in Fig. 28. 'l'he maximum allowable temperatures at critical points are $1400^{\circ} \mathrm{F}$ for 


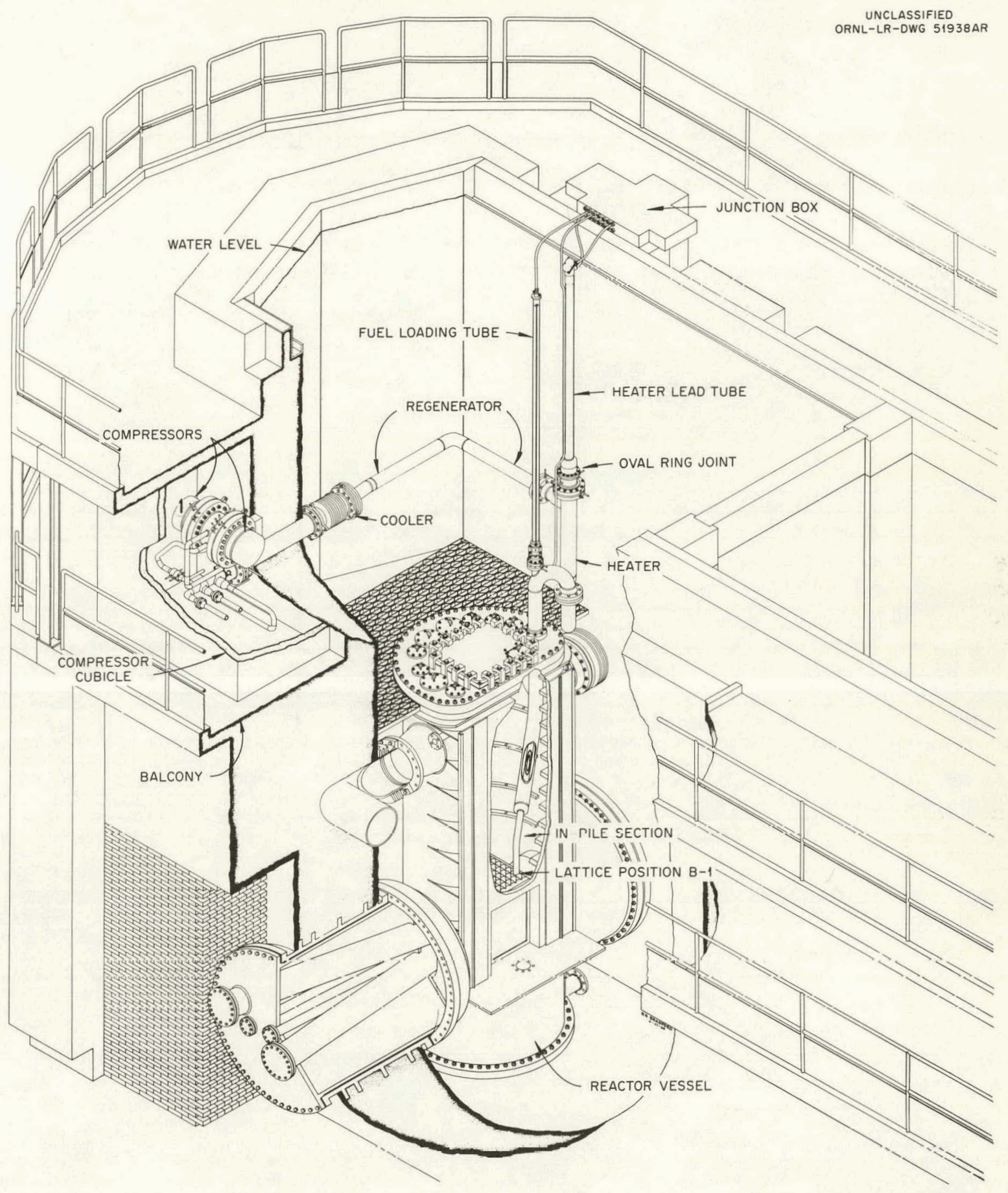

Fig. 25. GCR-ORR Loop No. I Principal Components and Their Relationship to the ORR Facility. 


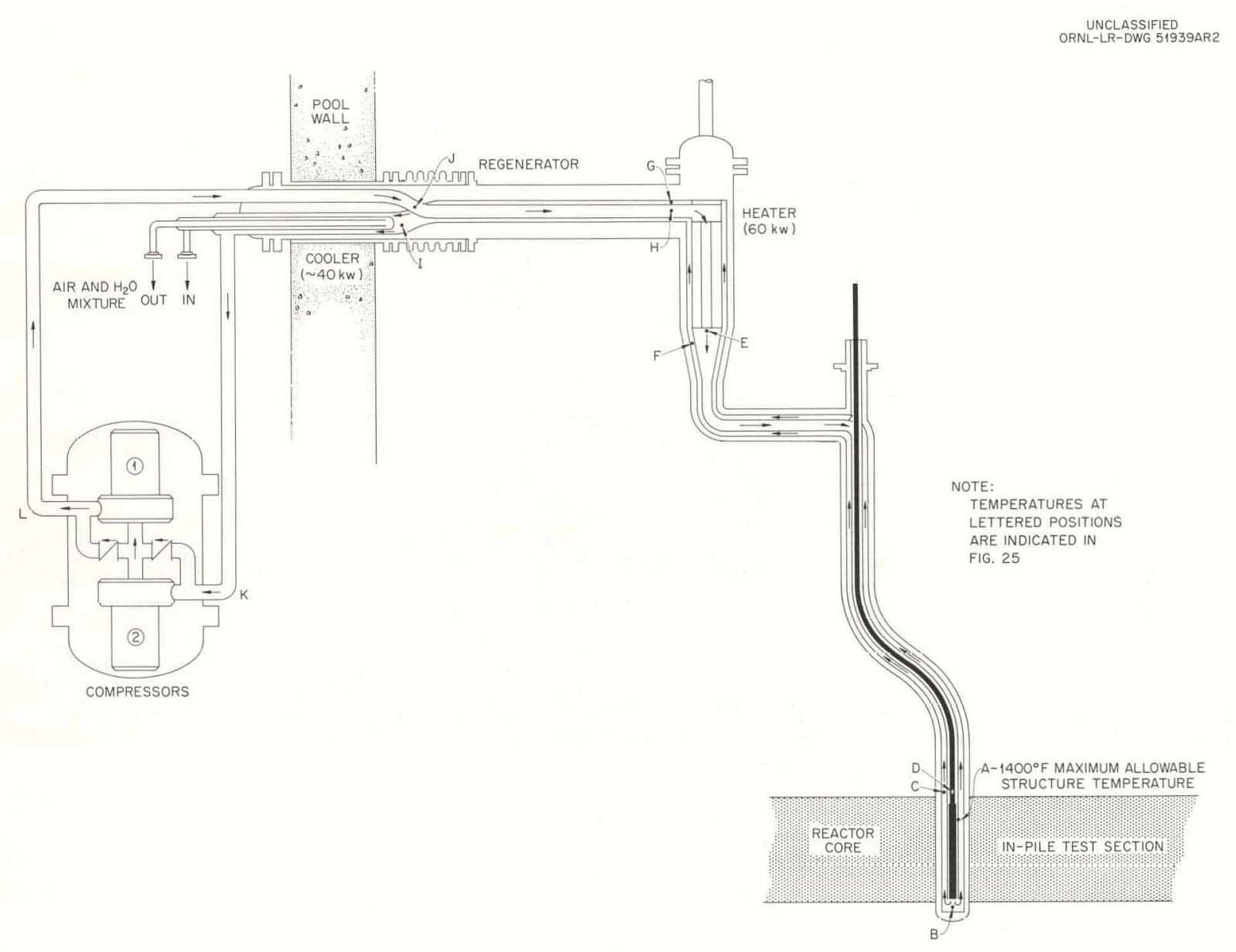

Fig. 26. GCR-ORR Loop No. I Schematic Flow Diagram. 


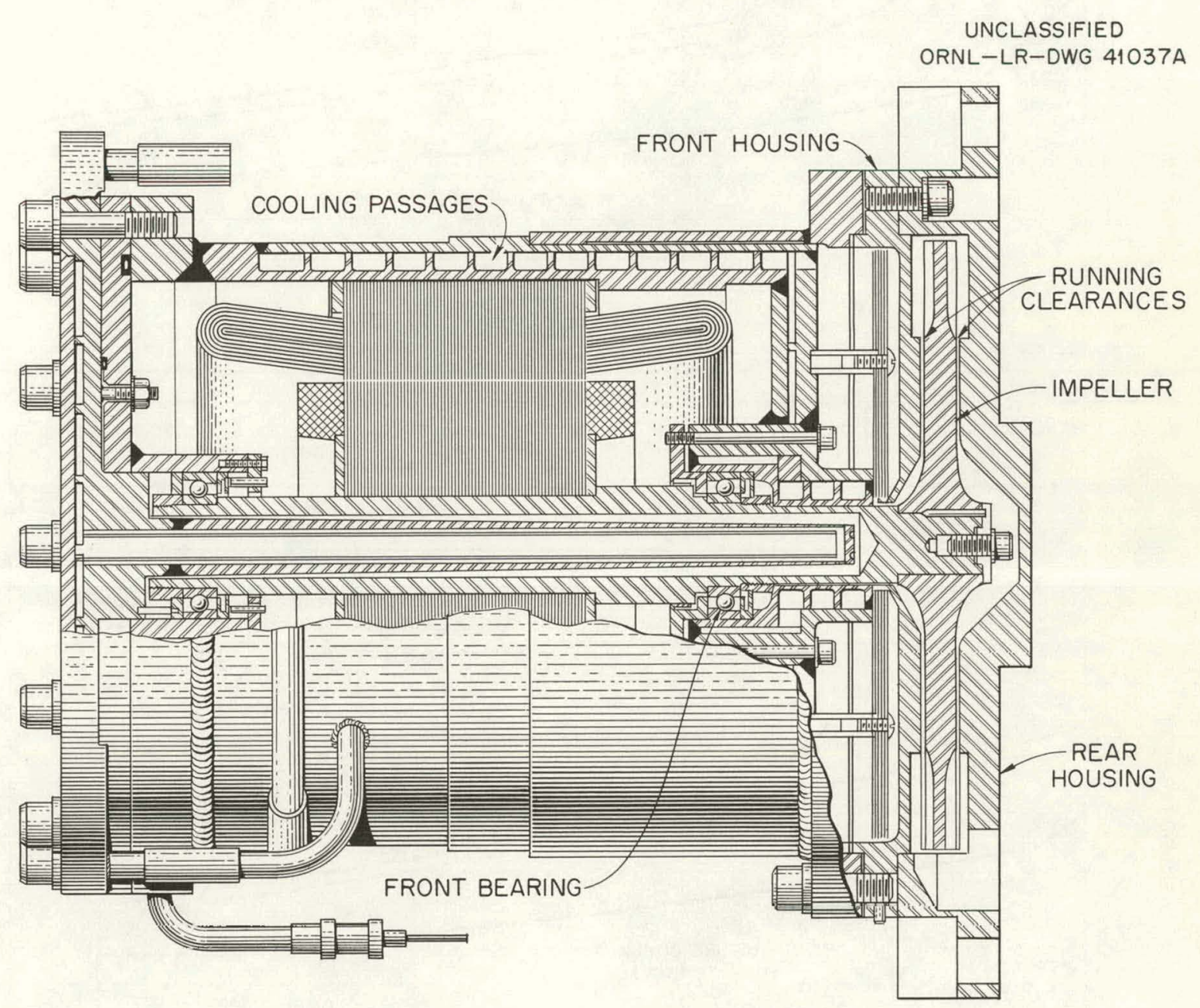

Fig. 27. HECT-II Compressor for GCR-ORR Loop No. 1. 

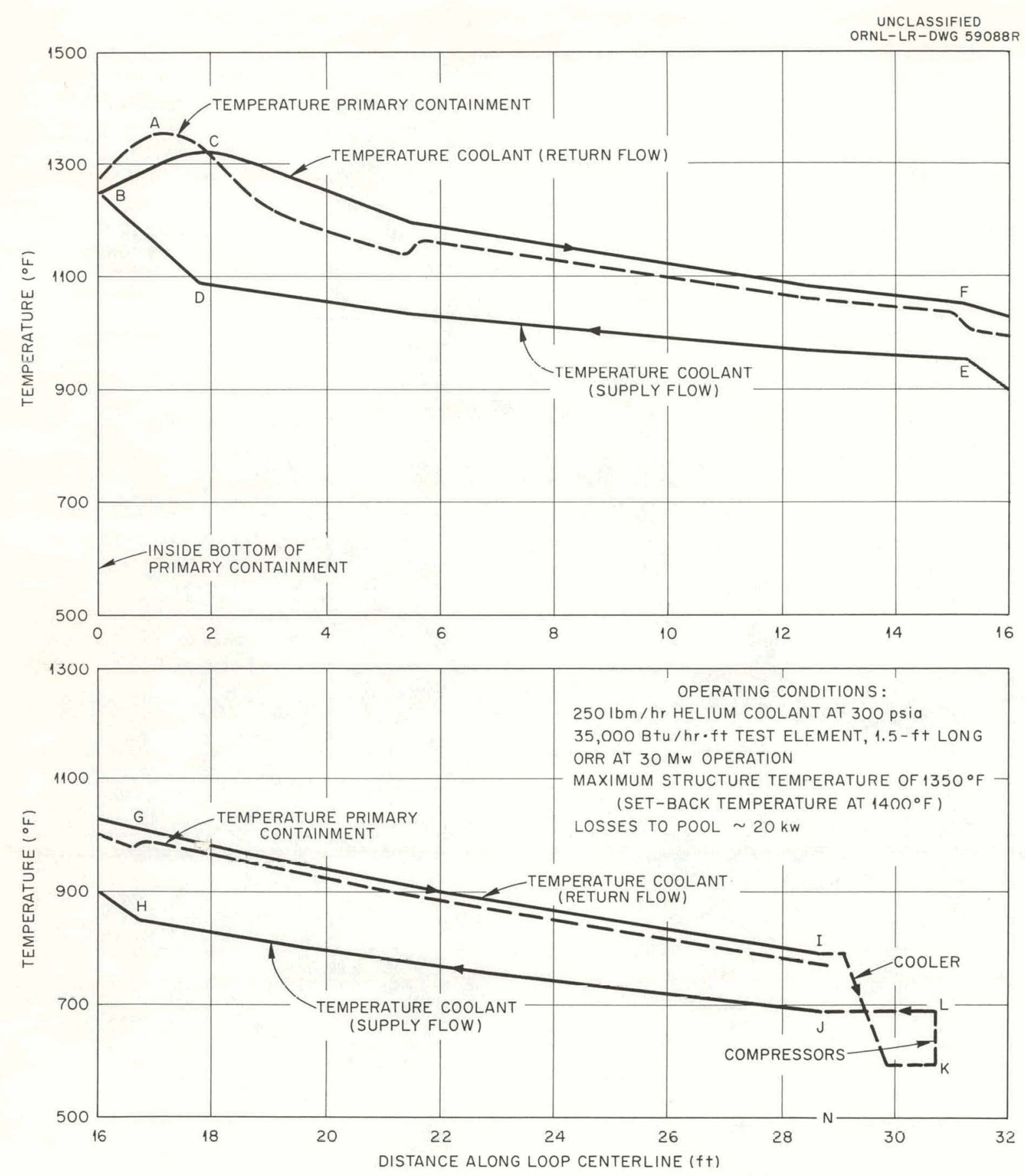

Fig. 28. Typical Temperature Distribution for GCR-ORR Loop No. 1. Letters on curves refer to lettered positions on Fig. 26. 
Table 3. Capacity of ORR Gas-Cooled In-Pile Loops

\begin{tabular}{|c|c|c|}
\hline & Loop ORR-1 & Loop ORR-2 \\
\hline Primary usage & Testing clad fue ${ }^{a}$ & Testing unclad fuel \\
\hline Startup date & JuIy 1961 & January 1963 \\
\hline $\begin{array}{l}\text { Thermal-neutron flux, } \\
\text { neutrons } / \mathrm{cm}^{2} \cdot \mathrm{sec}\end{array}$ & $5 \times 10^{13}$ & $8 \times 10^{12}$ \\
\hline $\begin{array}{l}\text { Fast-neutron (>0.1 Mev) flux, } \\
\text { neutrons } / \mathrm{cm}^{2} \cdot \mathrm{sec}\end{array}$ & $5 \times 10^{13}$ & $4 \times 10^{13}$ \\
\hline \multicolumn{3}{|l|}{ Specimen size (max), in. } \\
\hline $\begin{array}{l}\text { Outside diameter } \\
\text { Length }\end{array}$ & $\begin{array}{l}1 \\
19\end{array}$ & $\begin{array}{l}2.75 \\
9\end{array}$ \\
\hline Pressure (helium), psi & 300 & 300 \\
\hline $\begin{array}{l}\text { Fuel element temperature (max } \\
\text { measured), }{ }^{\circ} \mathrm{F}\end{array}$ & 4000 & 2500 \\
\hline $\begin{array}{l}\text { Coolant exit temperature } \\
(\max ),{ }^{\circ} \mathrm{F}\end{array}$ & 1400 & 1500 \\
\hline $\begin{array}{l}\text { Coolant inlet temperature } \\
(\max ),{ }^{\circ} \mathrm{F}\end{array}$ & 1350 & 1200 \\
\hline Flow rate $(\max ), 1 b / h r$ & 400 & 980 \\
\hline Heat removal limit, $\mathrm{kw}$ & 60 & $20^{b}$ \\
\hline Activity limitation, curies & 5 & $100^{c}$ \\
\hline
\end{tabular}

${ }^{a}$ Loop can also accommodate unclad ceramic, ventilated clad, or metal matrix elements.

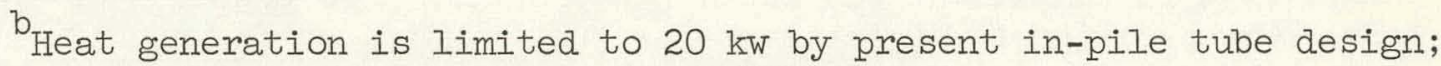
the loop has capability for removal of $60 \mathrm{kw}$.

With revision of equipment for fuel-element removal, operation could be permitted with 1000 curies of mixed fission-product activity in the coolant.

stress limits of the in-pile structure of the primary containment vessel and 600 to $800^{\circ} \mathrm{F}$ at the compressor inlet, as limited by the turbine wheel design and motor windings. Heat losses to the pool and in the compressor cubicle are made up by a 60-kw heater. Primary heat removal from the loop is accomplished by a bayonet type of cooler utilizing an air and water mixture, with the primary temperature control provided by varying the amount of water introduced into the air. Regenerative heat transfer in the arrular piping system is utilized to conserve energy while maintaining the inlet gas temperature to the fuel element as high as $1350^{\circ} \mathrm{F}$. The piping is essentially an all-welded system except at the loading station, 
heater cover, and the cooler bulkhead joint, which are flanged assemblies. The loop is doubly contained in its entirety to permit the testing of fuel elements under severe conditions without hazard. Loop instrumentation provides for continuous monitoring of important variables, including fuel, gas and loop structure temperatures, radiation levels, and all other parameters essential to safe operation. Helium released from the loop through normal venting or by overpressure relief valves passes through water-cooled activated-charcoal traps before being discharged to the ORR offgas system.

Gas-sampling provisions are adequate for determination of both chemical and radioactive noble gas impurities at very low levels. The conduit support for the fuel elements affords considerable surface area to collect fission or gaseous corrosion products and considerable space is available there for insertion of corrosion specimens and other experimental devices.

The loop operates nearly automatically but is manned with technicians to provide close adherence to the design test conditions, to ensure corrective action in the event of trouble, and to compensate for off-design reactor operation resulting from control action by other experiments. During two years of operation, the loop has caused a reactor shutdown on only one occasion. This shutdown was necessitated by serious failure of a fuel element under test. Operation has been continuous throughout all other reactor operating period.s.

Details of a typical fuel element for irradiation, equipment for installation and removal of hot elements, and sectional views of the inpile position of the loop are shown in Figs. 29 through 32. Figure 33 shows the loop and other equipment in the ORR pool, and Fig. 34 shows the instrument control panel.

Recent studies have shown the fast-neutron flux ( $\mathrm{E}>0.1 \mathrm{Mev}$ ) to be about $5 \times 10^{13}$ neutrons $/ \mathrm{cm}^{2}$. sec in the ORR B-1 core position of loop 1 . Thus the facility is of interest for fuel studies of gas-cooled reactors operating in the epithermal flux region. A fuel element test has demonstrated capability of the loop for operation with unclad fuel elements. Approximately 1 curie of noble-gas fission products released from a deliberately vented clad element was circulated in the loop for an extended. period.27 Following this operation, the loop was opened both for changeout of fuel and replacement of both compressors. No spread of contamination was cxperienced, and the changeout was completed easily within a normal ORR shutdown period.

The fuel test program for the loop has been intensive. During a little more than two years of operation, the loop has irradiated a total of 14 test specimens. With one exception, each test was conducted with quite satisfactory loop operation, although some tests resulted in failure of the specimen. A list of the experiments, their nature, and the operating conditions is given in Table 4. 
UNCLASSIFIED ORNL-LR-DWG 65160R4

CENTRAL THERMOCOUPLE-

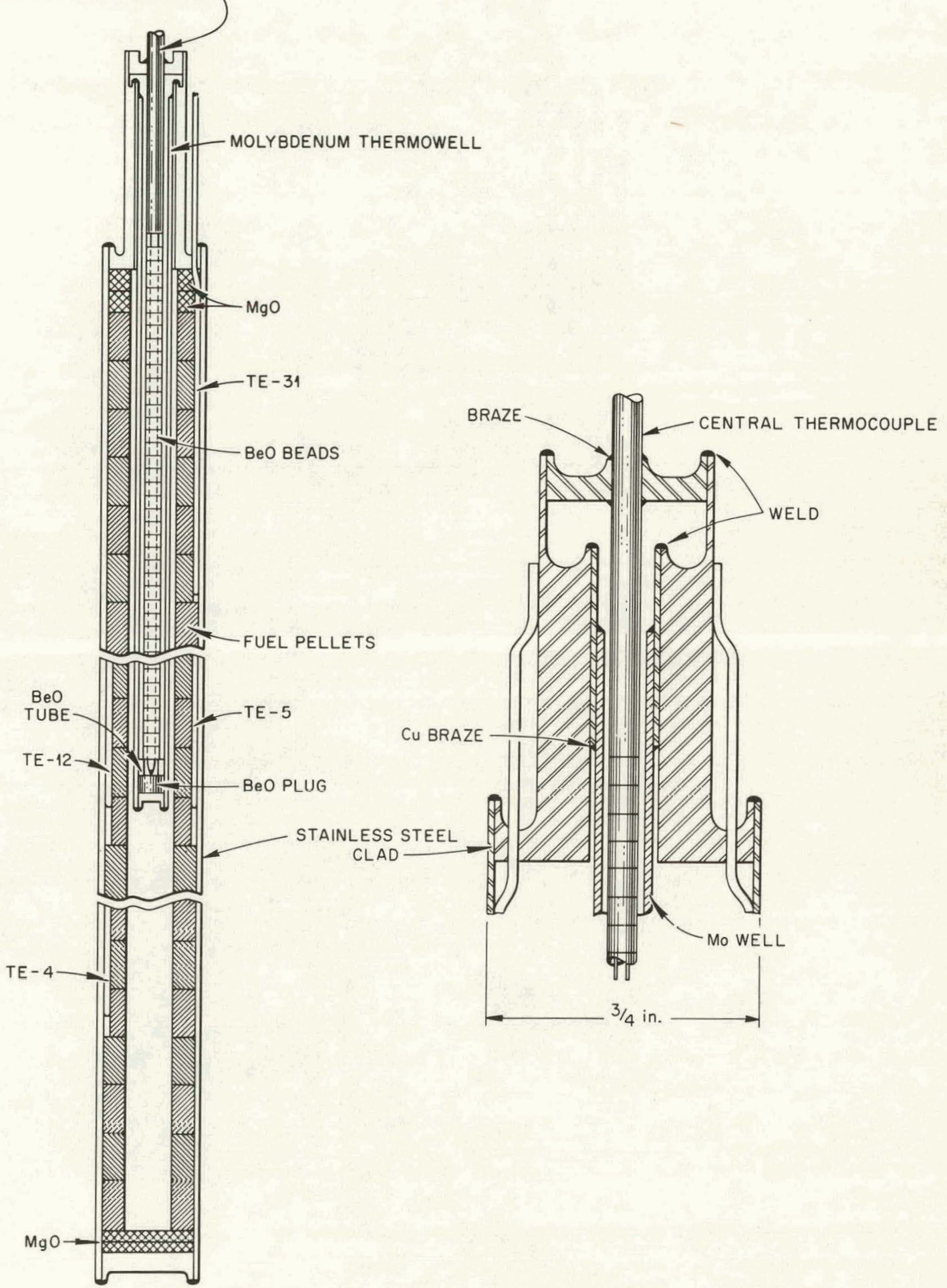

Fig. 29. Typical Test Fuel Element for Helium-Cooled Loop. 


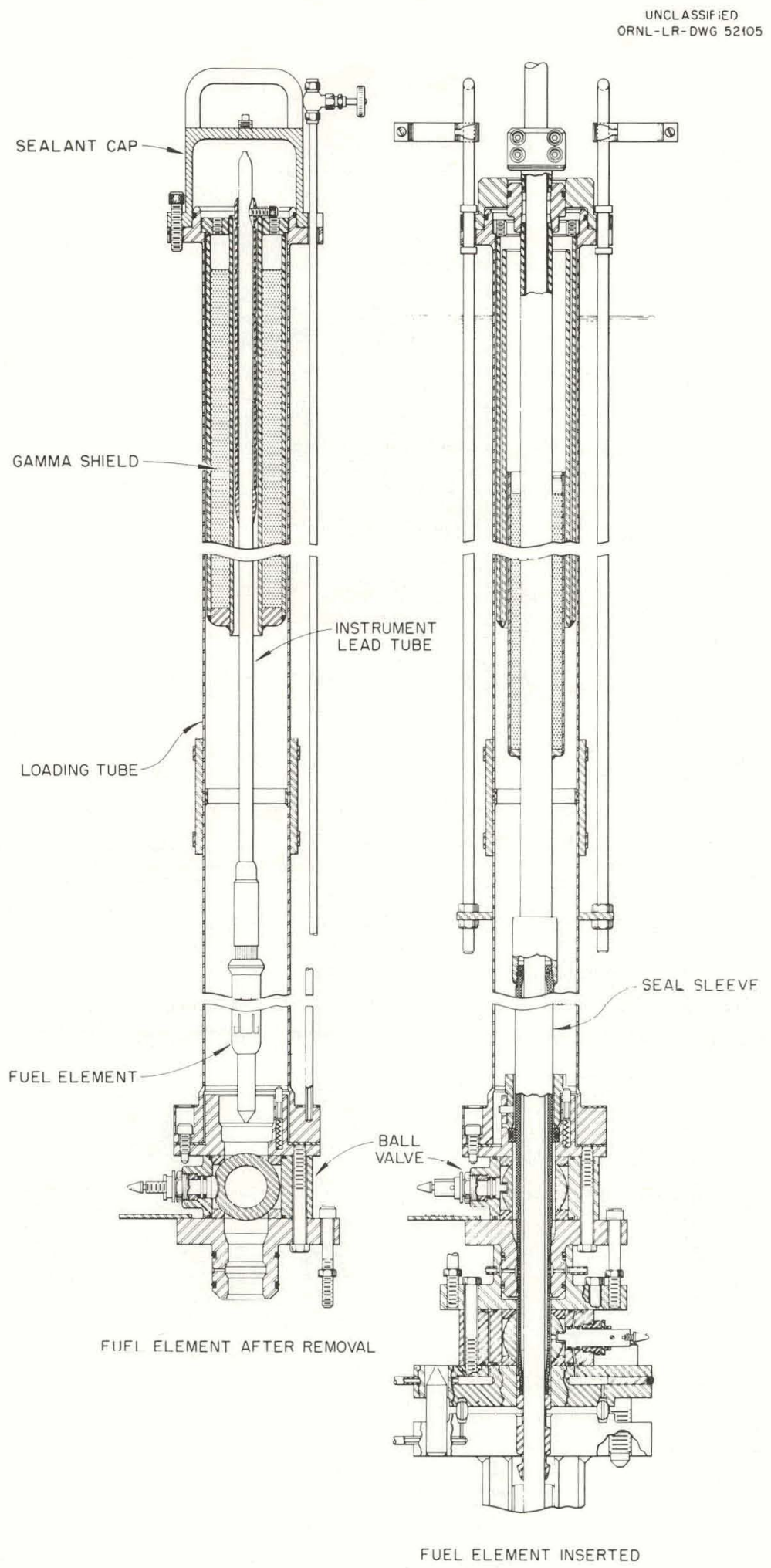

Fig. 30. GCR-ORR Loop No. I Loading Station. Irradiated fuel can be removed dry from the loop using ORR pool water for shielding during transfer to the ORR hot cell, where initial dismantling is performed. 
UNCLASSIFIED

ORNL-LR-DWG 52103

FLUX

MONITOR TUBE

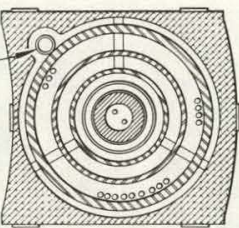

SECTION A-A

STRUCTURE

THERMOCOUPLES

) $r-A$

FUEL ELEMENT

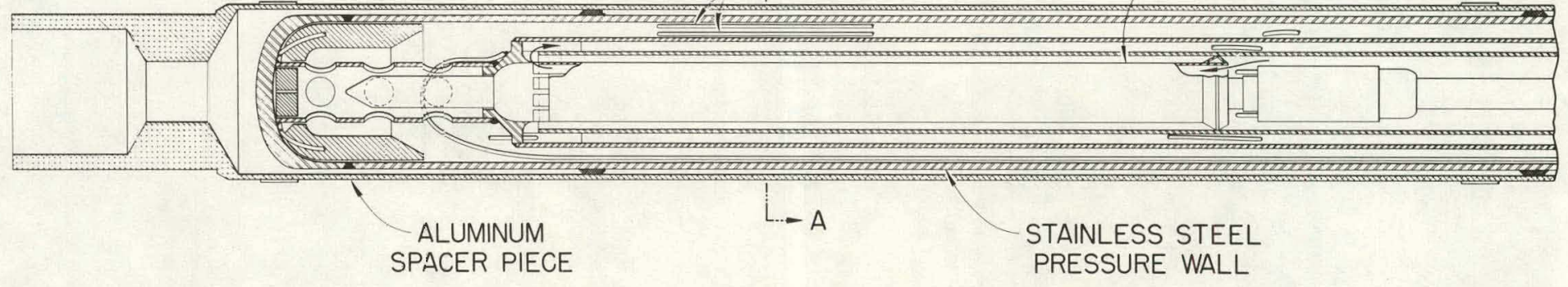

Fig. 31. Loop In-Pile Section. 


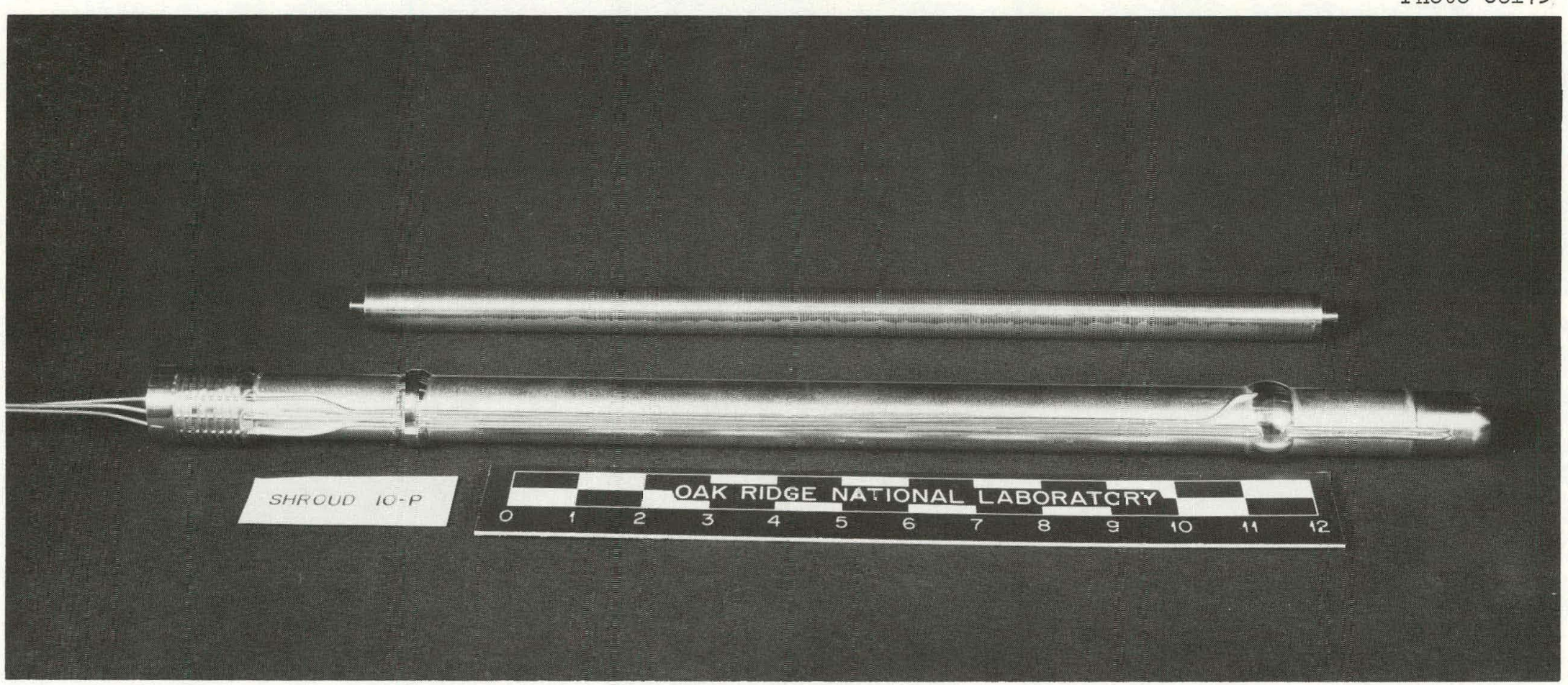

Fig. 32 . Loop No. I Fuel Elament and Shroud. Note that fuel element has wires krazed to the surface for roughening to enhance reat transfer. 


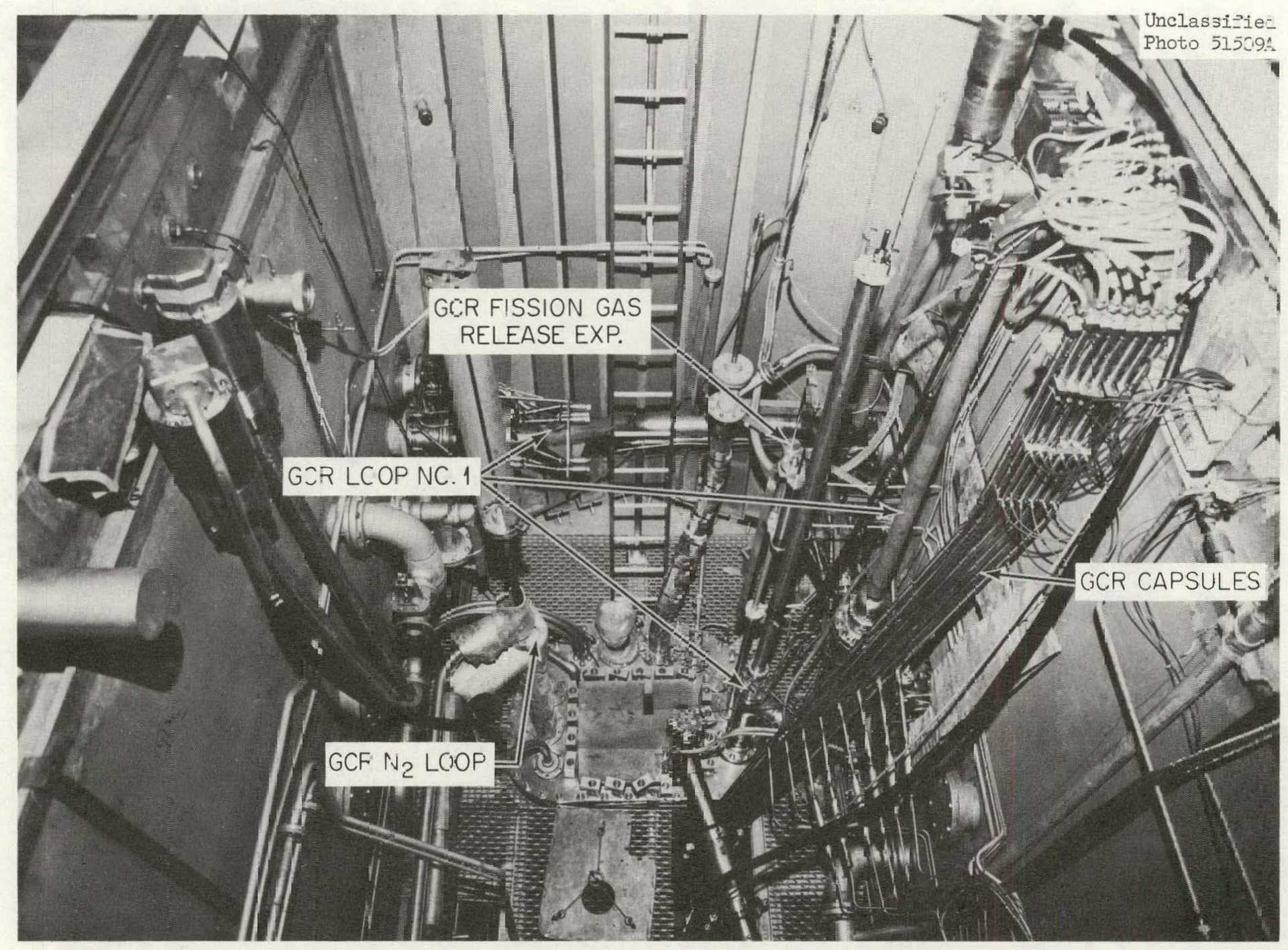

Fig. 33. Cak Ričge Fesearch Reactor with Gas-Ccoled Reactor Experiments Unçerway. 


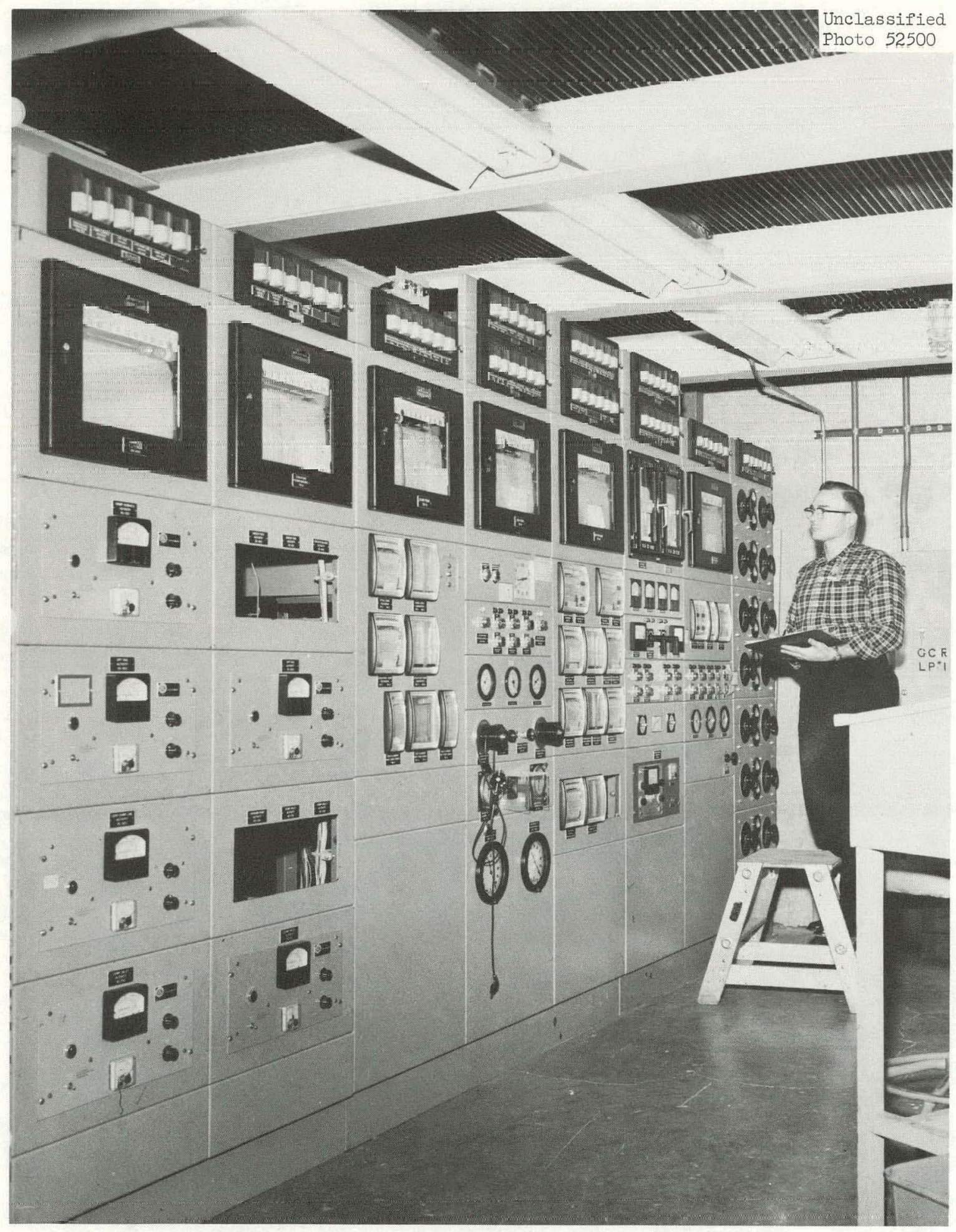

Fig. 34. GCR-ORR Loop No. I Instrument Panel. 
Table 4. Tests Conducted in Loop No. I

\begin{tabular}{|c|c|c|c|c|}
\hline $\begin{array}{l}\text { Test } \\
\text { Number }\end{array}$ & Sample & $\begin{array}{c}\text { Power } \\
(\text { Btu/hr·ft })\end{array}$ & $\begin{array}{l}\text { Maximum } \\
\text { Cladding } \\
\text { Temperature } \\
\left({ }^{\circ} \mathrm{F}\right)\end{array}$ & $\begin{array}{c}\text { Fuel } \\
\text { Central } \\
\text { Temperature } \\
\left({ }^{\circ} \mathrm{F}\right)\end{array}$ \\
\hline 1 & Pressure vessel steel & & 550 & \\
\hline 2 & Pressure vessel steel. & & 550 & \\
\hline 5 & EGCR type fuel element & 26,000 & 1450 & 1900 \\
\hline $6 \mathrm{~B}$ & EGCR type fuel element & 26,000 & 1200 & 1900 \\
\hline $7 \mathrm{~A}$ & EGCR type fuel element & 28,000 & 1450 & 2100 \\
\hline $7 B$ & EGCR type fuel element & 28,000 & 1450 & 2100 \\
\hline $7 \mathrm{C}$ & EGCR type fuel element & 28,000 & 1450 & 2100 \\
\hline 9 & EGCR type fuel element & 40,000 & 1540 & 2400 \\
\hline 8 & $\begin{array}{l}\text { Fuel element with trans- } \\
\text { verse fins }\end{array}$ & 40,000 & 1540 & 2400 \\
\hline $8 \mathrm{~S}$ & $\begin{array}{l}\text { Fuel element with trans- } \\
\text { verse fins }\end{array}$ & 40,000 & 1540 & (a) \\
\hline 1OP1 & $\begin{array}{l}\text { Fuel element with trans- } \\
\text { verse fins }\end{array}$ & 65,000 & 1540 & 3500 \\
\hline 10P2 & $\begin{array}{l}\text { Fuel element with trans- } \\
\text { verse fins }\end{array}$ & 50,000 & 1300 & 2600 \\
\hline $7 D$ & Ventilated fuel element & 26,000 & 1500 & 2100 \\
\hline $11 \mathrm{M}$ & $\begin{array}{l}\text { Fuel element with trans- } \\
\text { verse fins }\end{array}$ & 75,000 & 1500 & 3300 \\
\hline
\end{tabular}

$a_{\text {Thermocouple fuiled. }}$

ORR Gas-Cooled Loop No. 2

This facility provides for the irradiation of unclad fuel elements that may release fission products directly to the gas stream and for studies of fission-product behavior in a complex heat transfer system. A recirculating high-temperature helium loop is utilized for cooling the fuel and to simulate reactor systems. ${ }^{28}$ The irradiation test region located in the south beam hole of the ORR will accommodate fuel specimens up to $23 / 4 \mathrm{in}$. in diameter and 9 in. long. The piping immediately behind the fuel test region is arranged to accommodate various separately cooled or heated surfaces for studies of fission-product deposition. These surfaces are built integrally with the fuel test assemb $\perp y$ and are 
removed with the fuel for postirradiation examination. Sectional views of the loop test region are shown in Figs. 35 and 36. A heavily shielded carrier is provided for transfer of the irradiated specimen from the loop cell to a dismantling hot cell where critical parts are removed for examination in smaller cells.

The loop consists of 2 1/2-in.-diam, sched.-40, 300-series stainless steel pipe, compressors, an 80-kw electric heater, an evaporative cooler, a regenerative heat exchanger, a filter, the test section, and appropriate gas cleanup equipment. Instrumentation is provided to measure flows, pressures, temperatures, and radiation levels. Conversion of all gaspressure signals to electric output is provided consistent with the design of the loop containment. Loop controls are automatic to the extent possible and provision is made for reactor shutdown prior to development of abnormal conditions which would jeopardize the experiment, the loop, or its containment. An overall flow diagram of the loop is shown in Fig. 37.

A shielded full-flow filter is provided for general cleanup of the loop gas and, particularly, to collect fragments of unclad fuel elements which might be circulated in the loop. A side-stream purification system. removes chemical and radioactive contaminants from the helium during normal operation and, by proper valve settings, can be used to clean loop gas for discharge to the disposal stack. The design of the purification system is based on a limited flow of gas through a copper oxide bed, molecular sieve, and carbon trap. The carbon trap reduces activity by absorbing iodine and by delaying the noble fission gases for several halflives of radioactive decay. Krypton holdup is approximately $40 \mathrm{hr}$.

A sampling system is provided to remove helium coolant for quantitative analysis of noble fission gases and corrosion impurities, such as $\mathrm{CO}, \mathrm{CO}_{2}, \mathrm{H}_{2}, \mathrm{H}_{2} \mathrm{O}$, and $\mathrm{CH}_{4}$. Radioactive components are analyzed with a scintillation detector and a multichannel analyzer, which are also used. for fission-gas-release measurements in the ORR poolside capsules. A gas chromatograph is provided for on-line determination of chemical impurities. Impurity levels are easily maintained below 10 ppm during loop operation. The concentration of $\mathrm{CO}$ and $\mathrm{CO}_{2}$ can be held below 1 ppm or increased (by additions) to very high values, if desired, for studies of carbon transport effects.

All primary system components, including compressors and heat transfer and gas cleanup equipment, are located in a shielded cell adjacent to the ORR reactor pool wall. The arrangements of equipment and the cell design are shown in Figs. 38 and 39. The instrument panel is shown in Fig. 40. A hot-cell window and an omniscope provide for observation of the loop equipment during operation. Certain remote operations can be handled by a manipulator and a cell crane, which are controlled at the cell window. Individual components, in addition to being located in the cell, are shielded to permit operation with heavily contaminated gas streams without buildup of activity to levels that would prevent access by operators and maintenance personnel during reactor shutdown periods. 
UNCLASSIFIED
ORNL-DWG $63-1172$

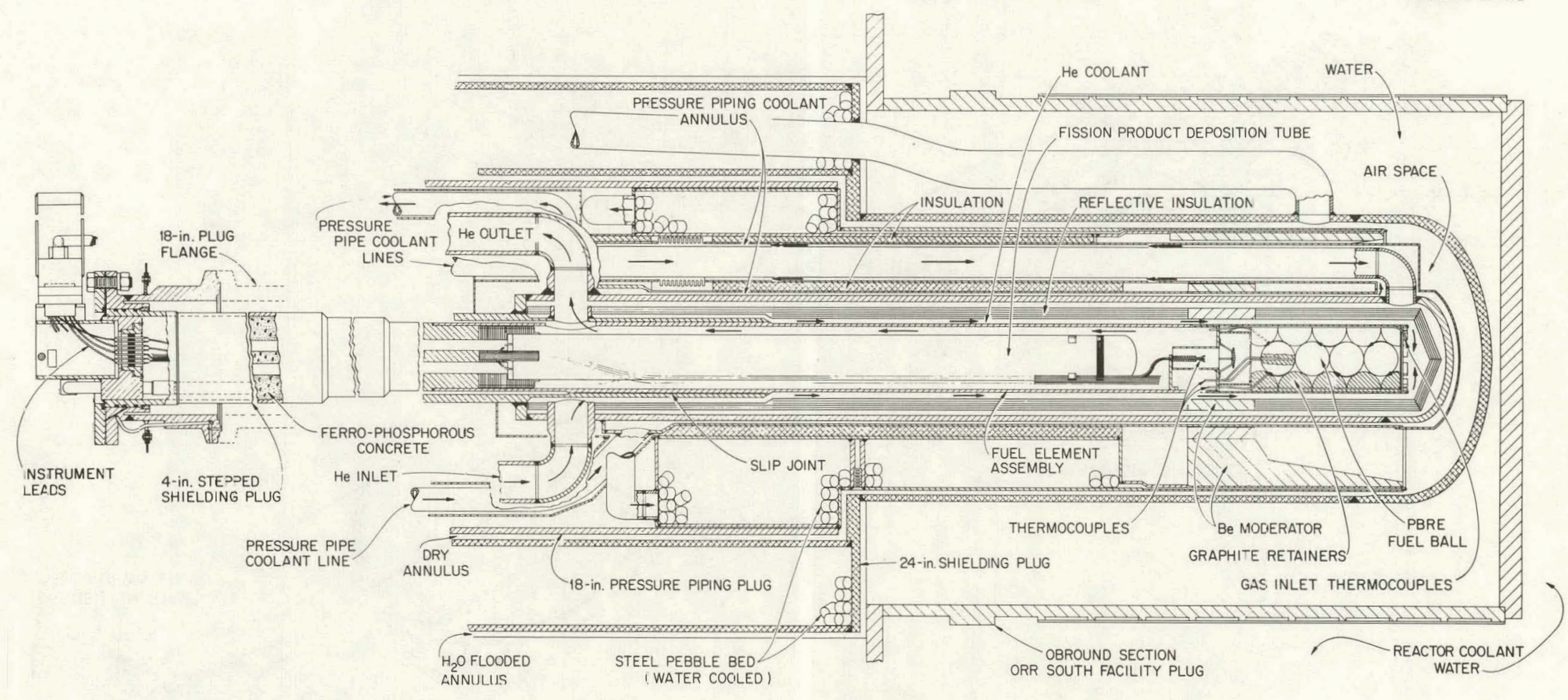

Fig. 35. Assembly for Tests of Fueled-Graphite Spheres in GCR-ORR

Loop No. 2 . 


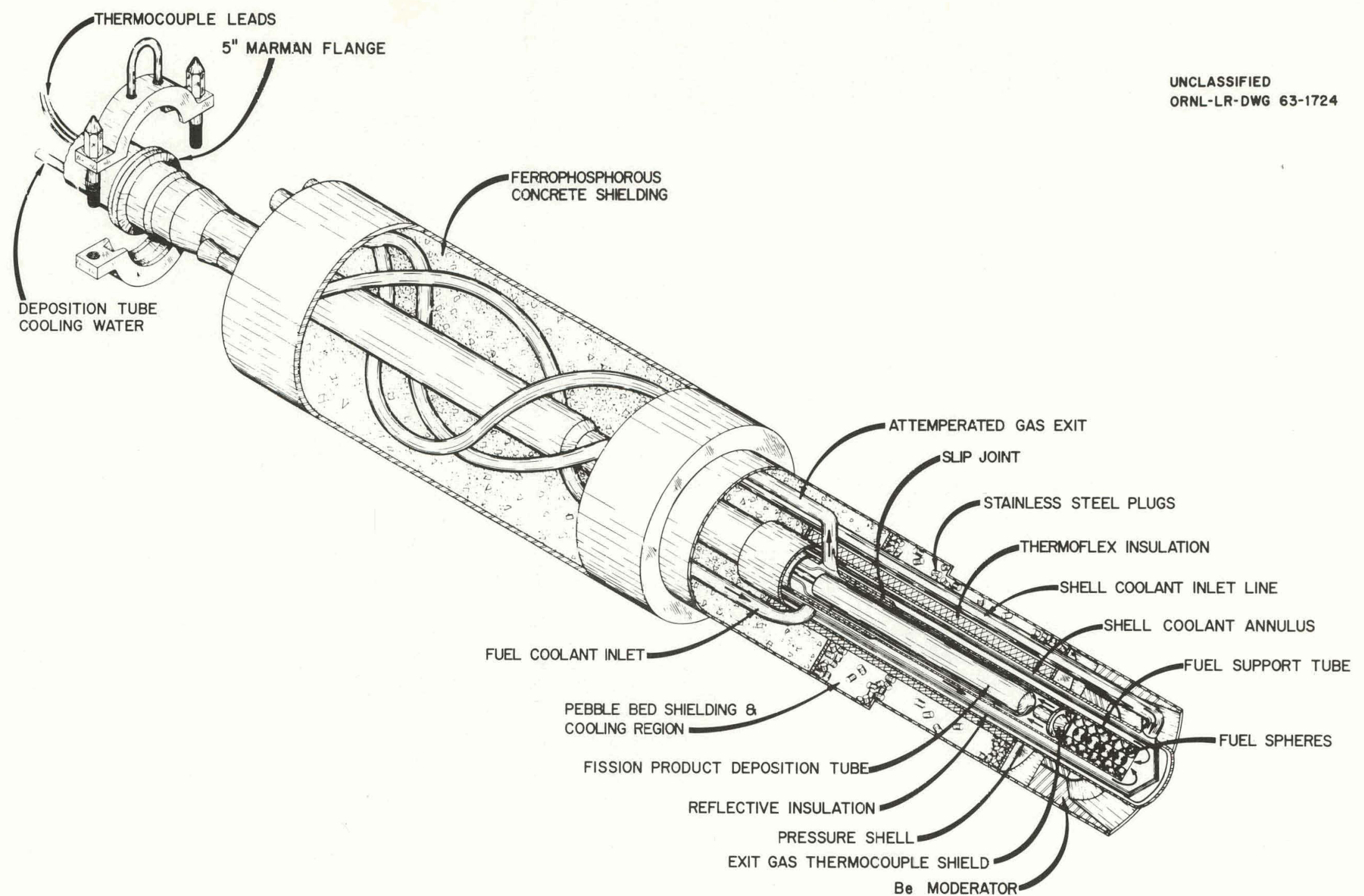

Fig. 36. GCR-ORR Loop No. 2 In-Pile Section. 


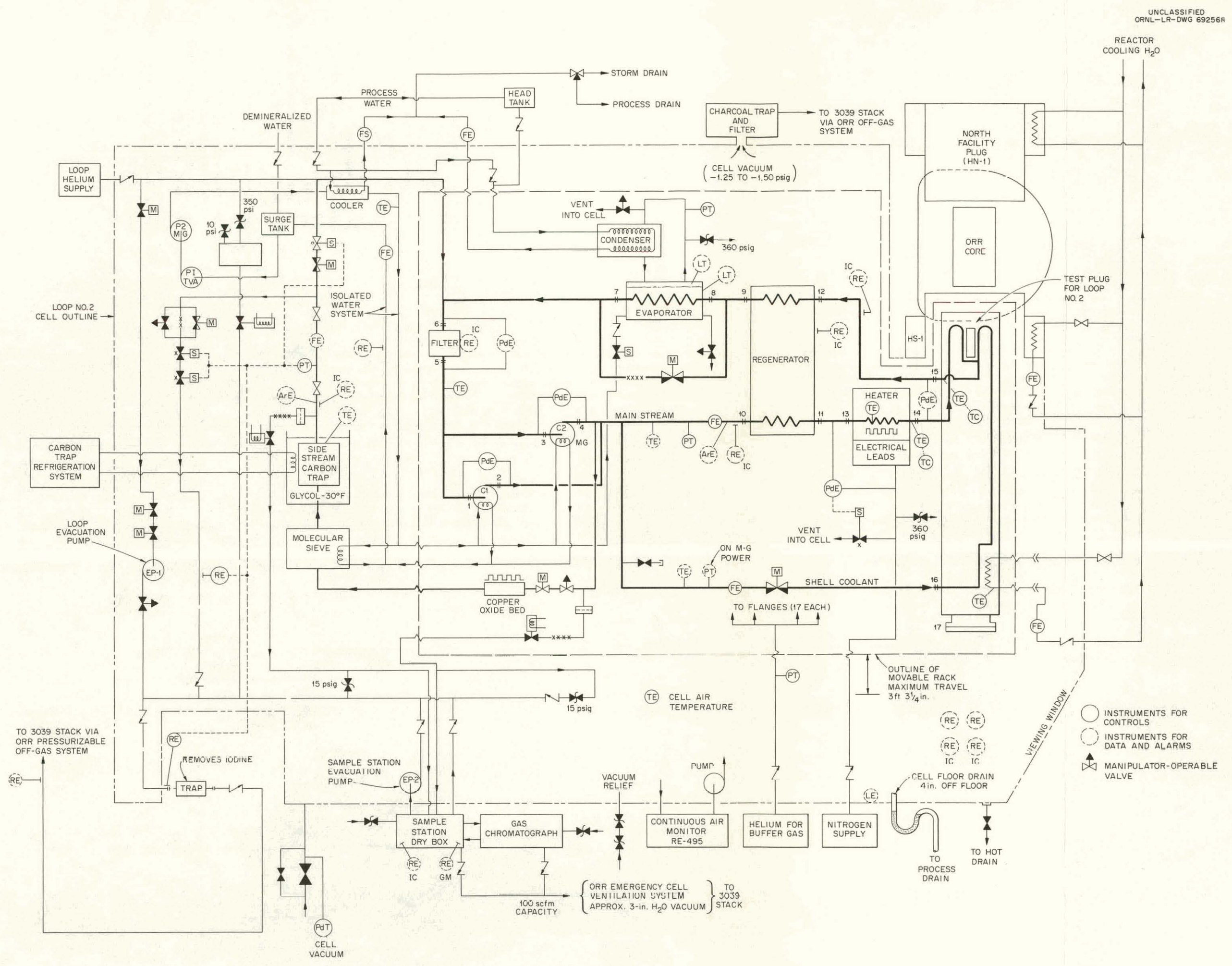

Fig. 37. Composite Flow Diagram of GCR-ORR Loop No. 2. 


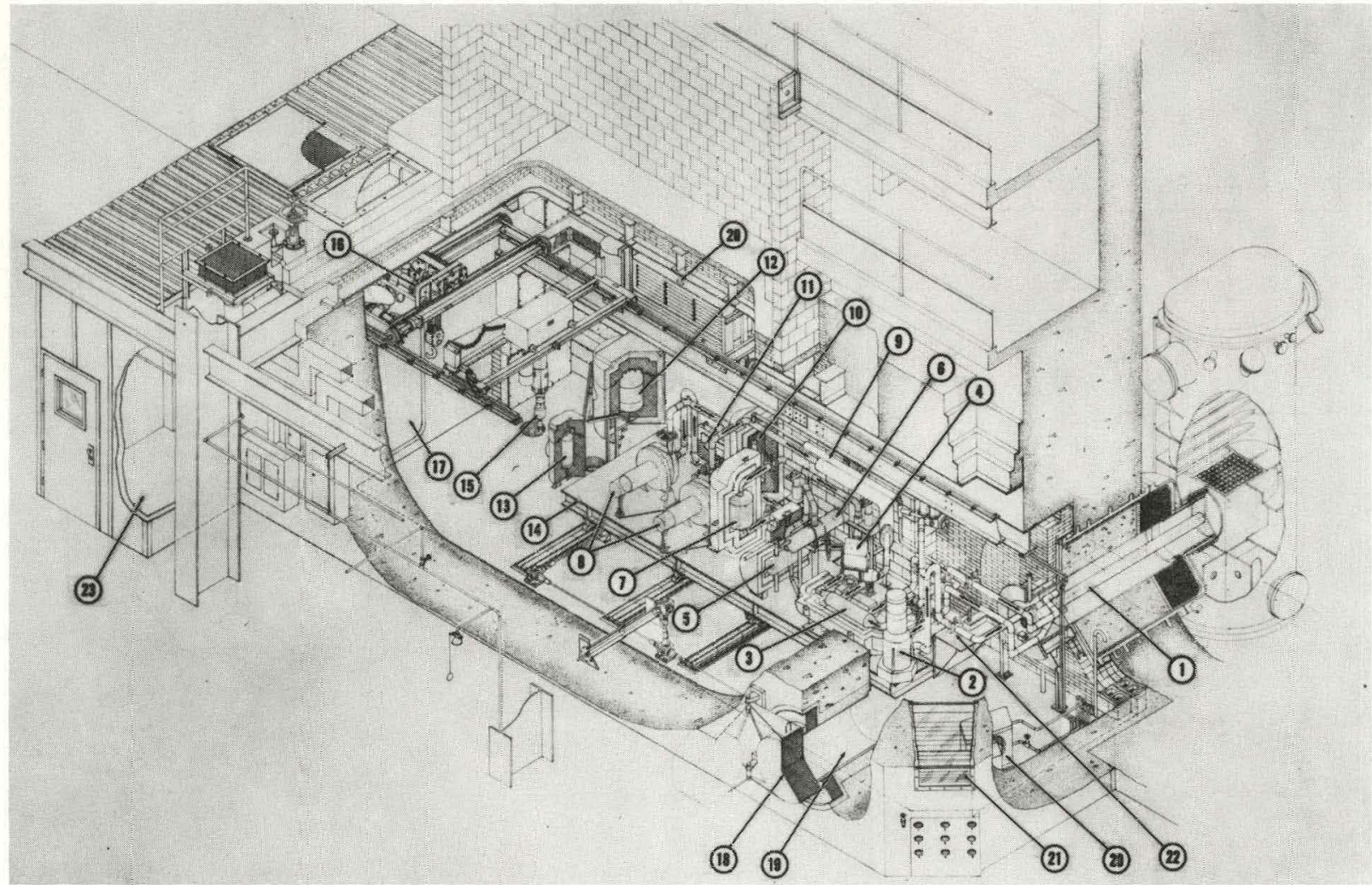
1. FUEL TEST TUBE
2. HEATER
3. REGENERATER
4. EVAPORATOR BY-PASS VALVE
5. EVAPORATOR
6. CONDENSER
7. FILTER
8. COMPRESSORS
9. SHELL COOLANT STREAM
10. CUO BED
1. SIDE STREAM COOLER
12. SIDE STREAM CARBON TRAP
13. MOLECULAR SIEVE
4. MOVABLE RACK
15. REMOTE MANIPULATOR
16. 5-TON CRANE
17. PERSONNEL ACCESS DOOR
18. EXTERNAL SHIELD DOOR
18. EXTERNAL SHIELD DOOR
19. TEST PLUG REMOVAL SLEEVE
20. SPACE COOLERS
21. VIEWING WINDOW
22. MARMON SEAL FLANGE
23. AIR LOCK

Fig. 38. Diagram of GCR-ORR Loop No. 2. 


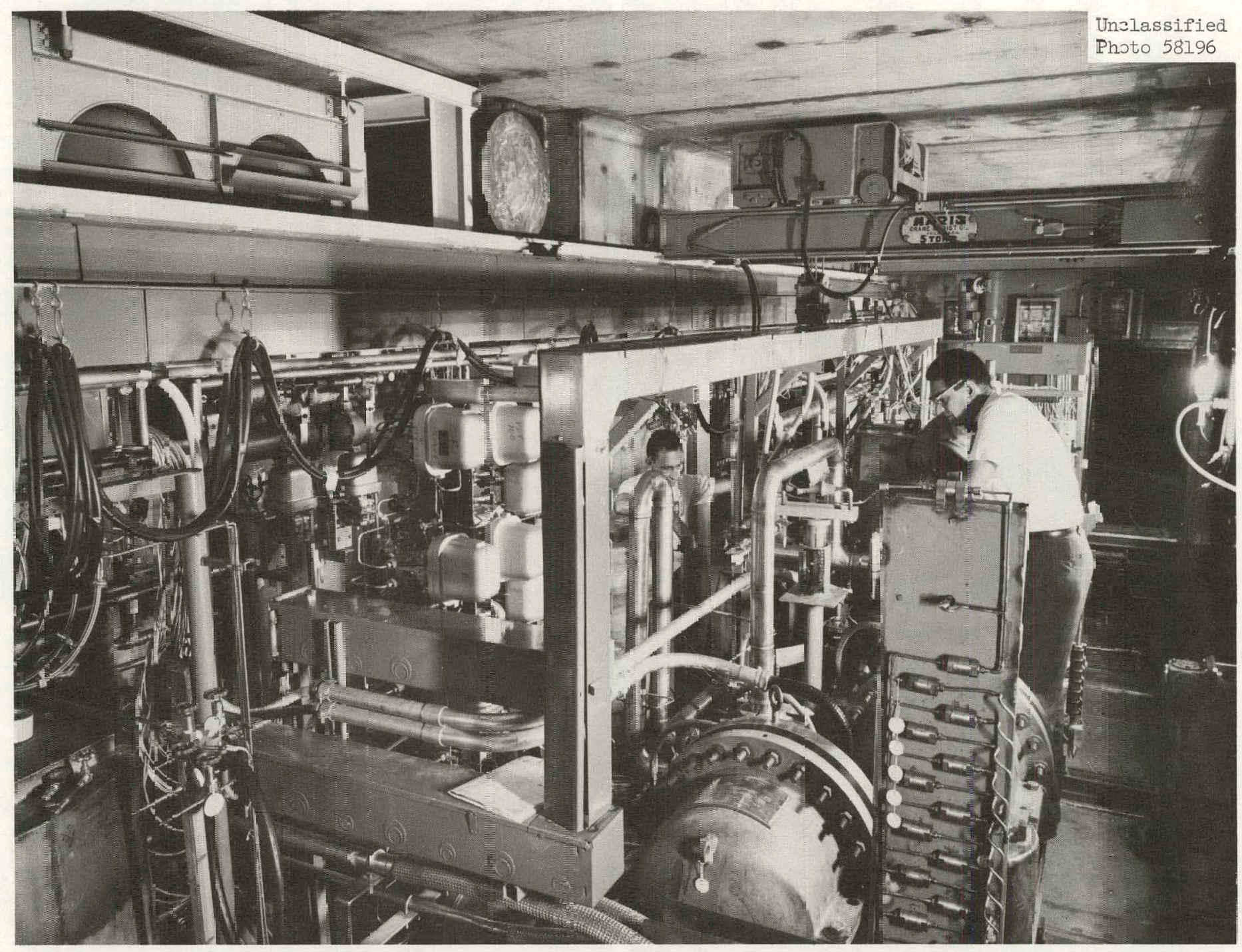

Fig. 39. View of LoO No. 2 Equipmert in the Containmen- Cell. A compressor hoving is prominent in the lower right foreground. 


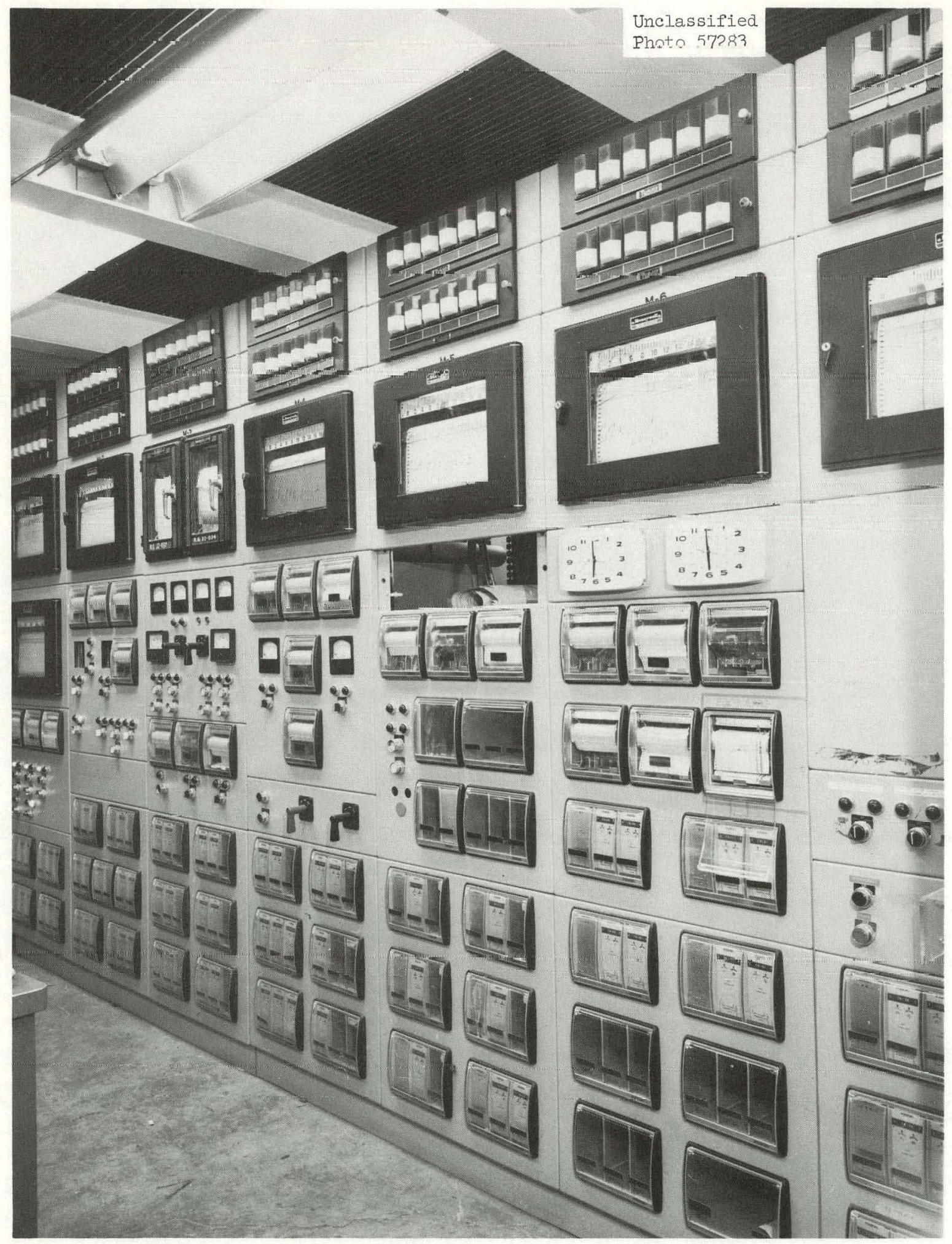

Fig. 40. Instrument Control Panel for Loop No. 2. 
Three experiments have been conducted in the loop, as listed in Table 5. The first utilized a small quantity of $\mathrm{UO}_{2}$ as a calibration test sample for radioactivity release and for determining the operability of the loop equipment for handling and detecting fission products. The second and third tests involved spherical elements containing pyrolyticcarbon-coated $\mathrm{UC}_{2}$ fuel in a graphite matrix structure.17,18 Each test has proceeded smoothly during operation. Removal of the irradiated pieces following the first two tests has been accomplished routinely, and the third test is in progress.

Table 5. Fuel Tests Conducted in Loop No. 2

\begin{tabular}{llcc}
\hline $\begin{array}{c}\text { Type of } \\
\text { Test }\end{array}$ & \multicolumn{1}{c}{ Fuel Element } & $\begin{array}{c}\text { Power } \\
(\mathrm{kW})\end{array}$ & $\begin{array}{c}\text { Fuel } \\
\text { Central } \\
\text { Temperature } \\
\left({ }^{\circ} \mathrm{F}\right)\end{array}$ \\
\hline Shakedown & $\mathrm{UO}_{2}$ film & Negligible & 1100 \\
Fuel stability & $\begin{array}{l}\text { Four spheres, I I/2 in. in di- } \\
\text { ameter, consisting of pyro- } \\
\text { lytic-carbon-coated particles } \\
\text { in a graphite matrix }\end{array}$ & 4 & 1400 \\
Fuel stability & $\begin{array}{l}\text { Three spheres, 2.38 in. in di- } \\
\text { ameter, consisting of pyro- } \\
\text { lytic-carbon-coated particles } \\
\text { in a graphite matrix }\end{array}$ & 5 & 1650 \\
\hline
\end{tabular}

$\underline{\text { ORR Pressurized-Water Loop }}$

This test facility, in which fuel and other materials can be subjected to radiation and other environmental conditions simulating a pressurized-water reactor system, has been operated in the Oak Ridge Research Reactor since December 1959. It was designed for tests of stainless steel-clad fuel elements containing $\mathrm{UO}_{2}$ or other ceramic fuels. The initial tests in the loop were conducted to evaluate fuel elements for N.S. SAVANNAH replacement cores. ${ }^{29,30}$ Pellets, swaged-powder, and vibration-compacted bulk fuels in cylindrical elements and dispersion fuels in flat coupons and hollow cylinders have been irradiated. The A-l and A-2 core positions of the ORR are utilized to accommodate multiple element assemblies. The test $100 \mathrm{p}$ is designed to recirculate water at 2500 psig, $650^{\circ} \mathrm{F}$, and $80 \mathrm{gpm}$ with a heat removal capacity of $300 \mathrm{kw} .{ }^{31}$ The piping within the reactor is arranged as a $U$ tube with straight vertical access through the reactor vessel cover. An isometric view of the loop as installed at the ORR is shown in Fig. 4I, and a schematic flow diagram 


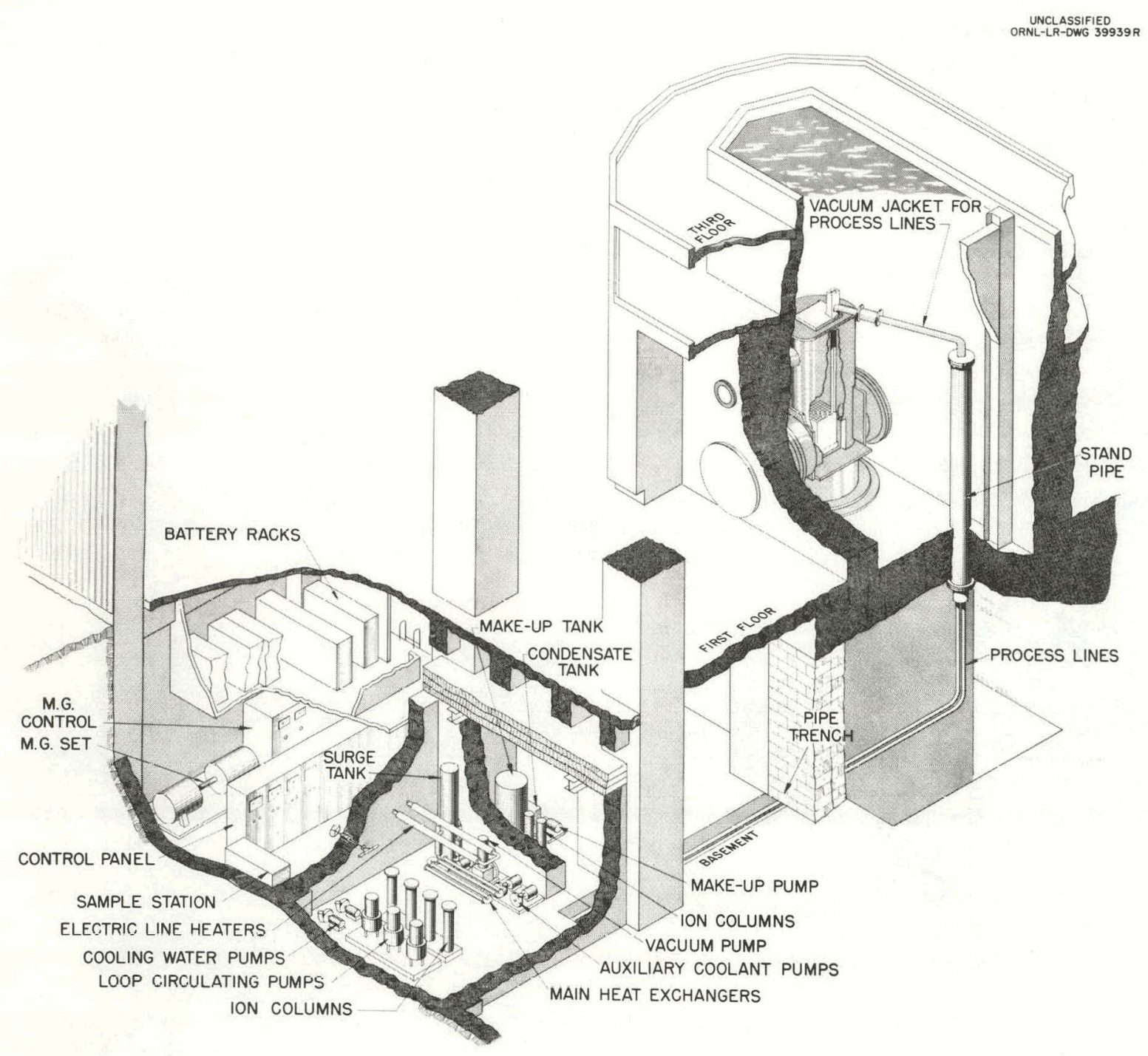

Fig. 41. Pressurized-Water Loop in the ORR. 
is presented in Fig. 42. The in-pile piping is type 316 stainless steel; elsewhere, type 347 stainless steel was used. The maximum perturbed thermal-neutron flux is $7 \times 10^{13}$ neutrons $/ \mathrm{cm}^{2} \cdot \mathrm{sec}$, and the peak gamma heat is approximately $5 \mathrm{w} / \mathrm{g}$.

The legs of the $U$ tube are encased in stainless steel vacuum jackets, which provide thermal insulation and secondary containment. The assembly fits into two modified ORR experiment core-pieces, as shown in Fig. 43. Each is sealed with an O-ring gasket in a "breachlock" flange closure above the reactor vessel, which is opened for insertion and removal of test assemblies. Above this point, $11 \mathrm{ft}$ of pool water serves as a shield during the removal operation. The arrangement of the ORR pool and hot cell is convenient and safe for test-specimen removal, storage, inspection, and preparation for shipment. A special containment vessel and equipment for removal of ruptured fuel specimens is available; however, no serious fuel failures have occurred. Photographs of typical test fuel element assemblies are shown in Figs. 44 and 45.

In order to ensure reliability of cooling for fuel elements, the three main loop pumps are arranged in parallel with check valves and an electrical control system that will start another pump automatically if the operating unit fails. A dc-ac motor-generator set with rectifier and batteries operates continuously and is available to provide the power needs for loop cooling. It also serves as a second power source for GCRORR loops 1 and 2. An isolated water system separates the loop primary system from the reactor pool cooling water system to which the heat generated in the loop is dissipated. The loop is pressurized from a separately heated tank equipped with vapor flash nozzles and vents for degassing. The loop is well equipped with fill, vent, and drain lines that terminate at the sampling station. In Fig. 46, the sampling station is in the background with the loop control panel on the right and the cell shielding wall with loop valve extension handles at the left.

An out-of-pile test section is located with the auxiliary equipment in a shielded cell in the basement of the $O R R$ building. This provides convenient access for insertion of nonnuclear experimental equipment, such as electrically heated surfaces and special filters. Water samples can be removed at loop operating temperatures. Ion exchangers are provided in the loop fill system and in a bypass stream to maintain the necessary water purity and $\mathrm{pH}$. Hydrogen additions can be made to scavenge oxygen and reduce radiolytic decomposition. A small high-temperature bypass stream makes possible tests of small filtration devices located at the sample station.

All loop components have operated satisfactorily. Leakage has been negligible, with makeup required only for replacement of the water removed. by sampling. Oxygen concentrations are consistently below 0.020 ppm with addition of hydrogen. Particulate matter is also found to be at low levels of concentration: $\sim 1$ to $4 \mathrm{ppm}$. This has resulted in low contamination in the equipment room; the activity is usually below personnel tolerance levels. Direct radiation levels in the equipment room are near 
UNCLASSIFIED

ORNL-LR-DWG $39807 R$

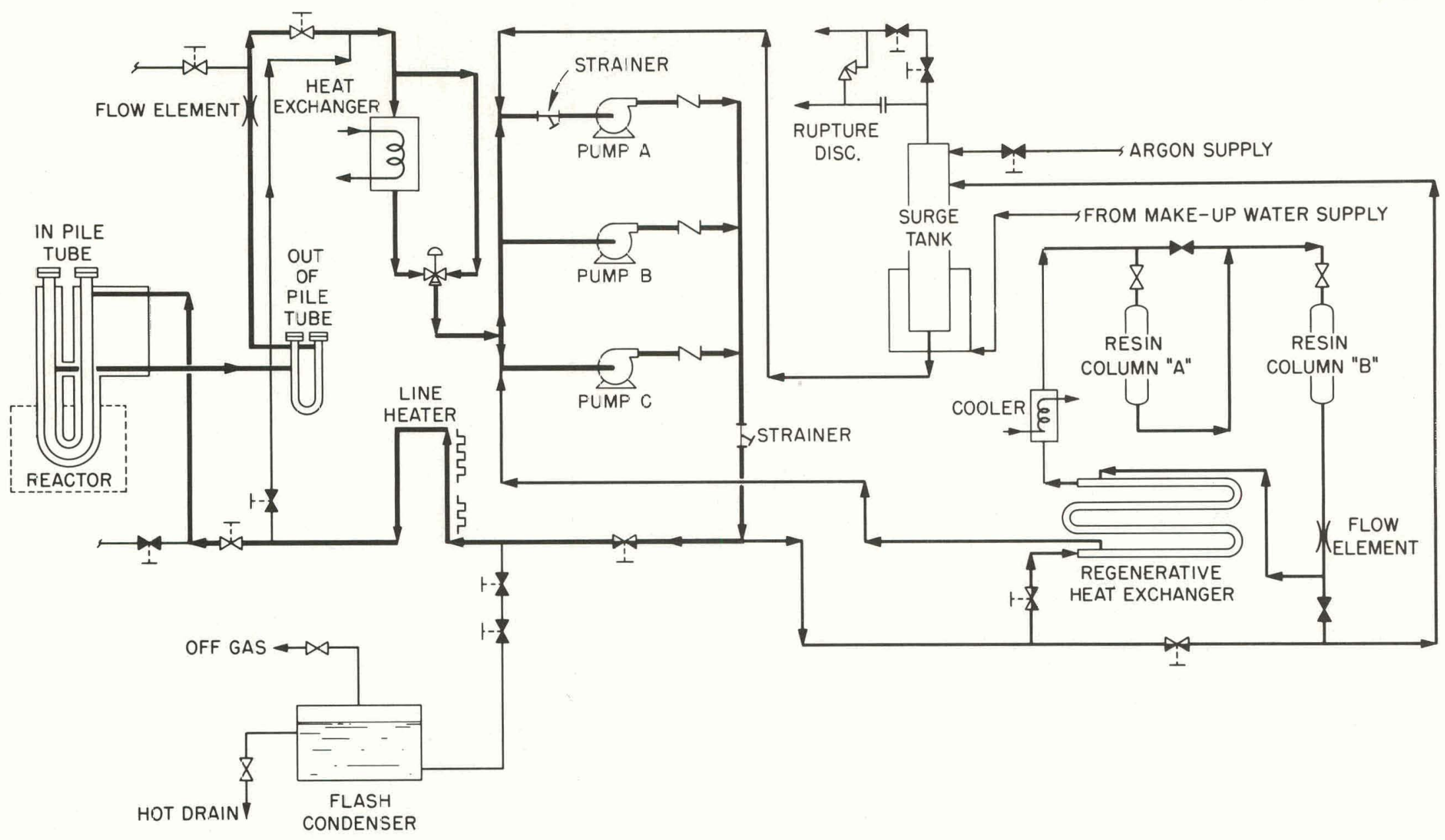

Fig. 42. Simplified. Flow Diagram of Pressurized-Water Loop. 


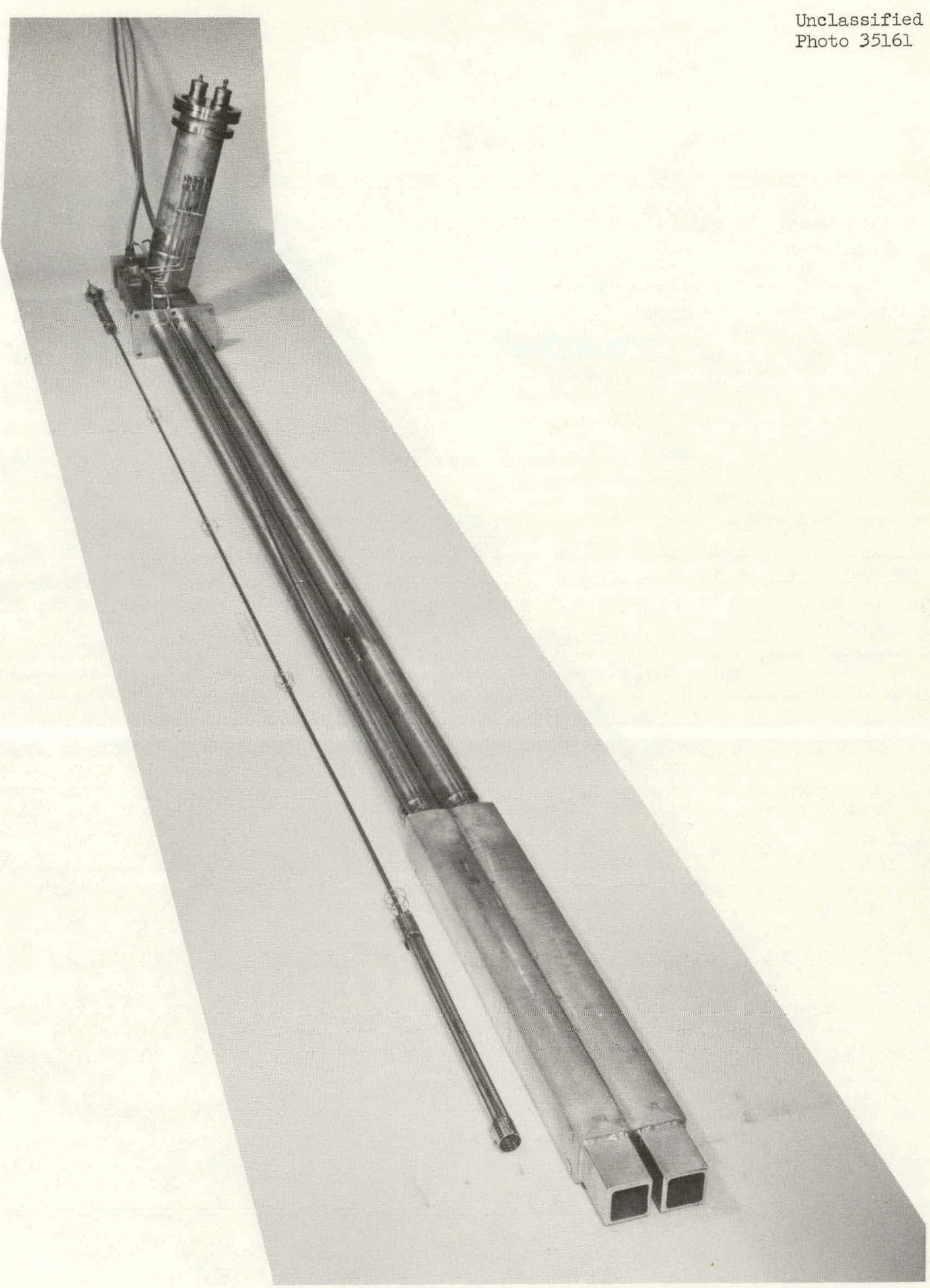

Fig. 43. In-Pile U-Tube Assembly for Pressurized-Water Loop. Tee section at the top is welded to loop. Modified ORR core pieces for positions $A-1$ and $A-2$ are in the foreground. The experiment assembly and support tube for one leg are shown at the left. 


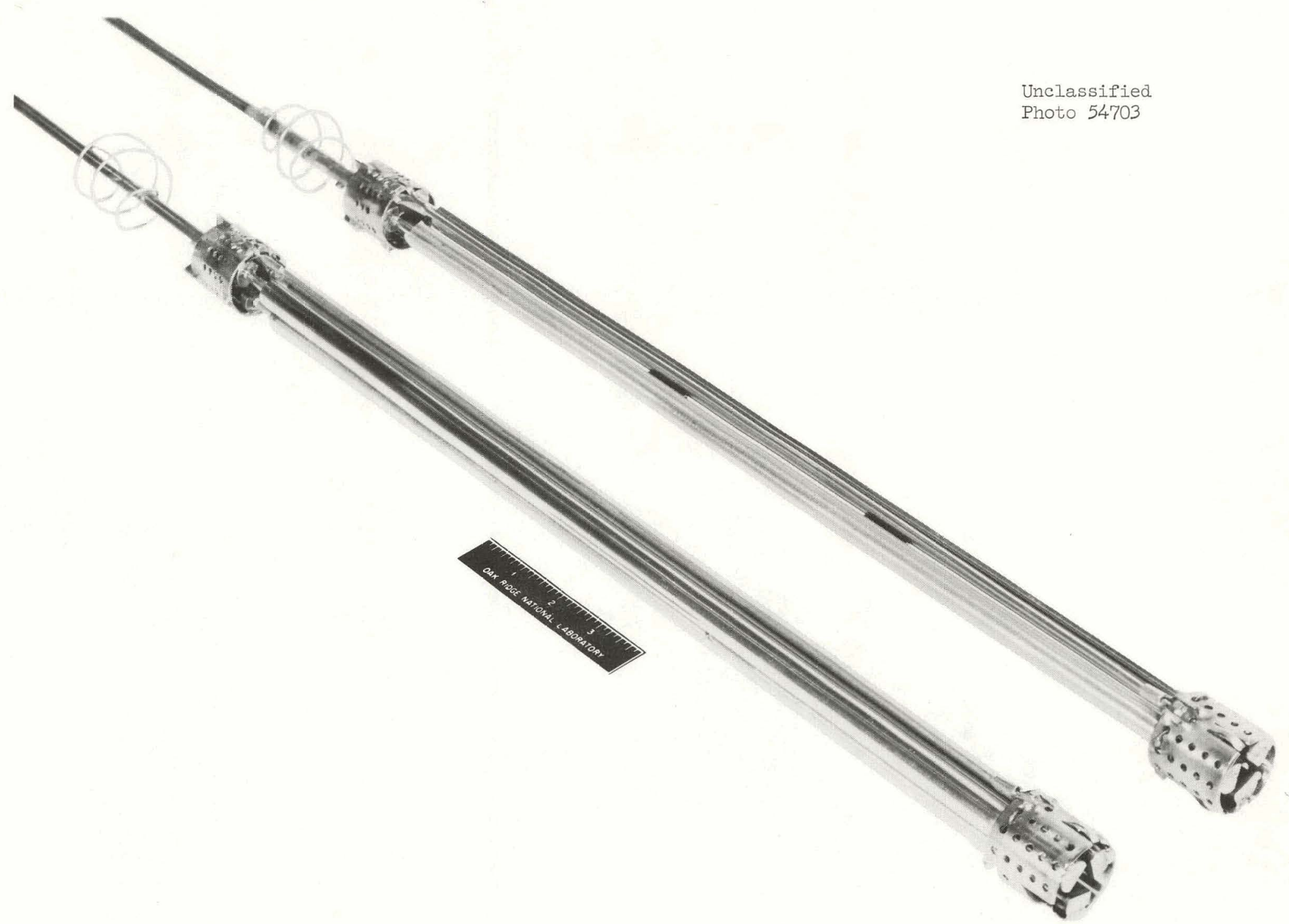

Fig. 44. Two Three-Fin Assemblies for Irradiation in the PressurizedWater Loop. 


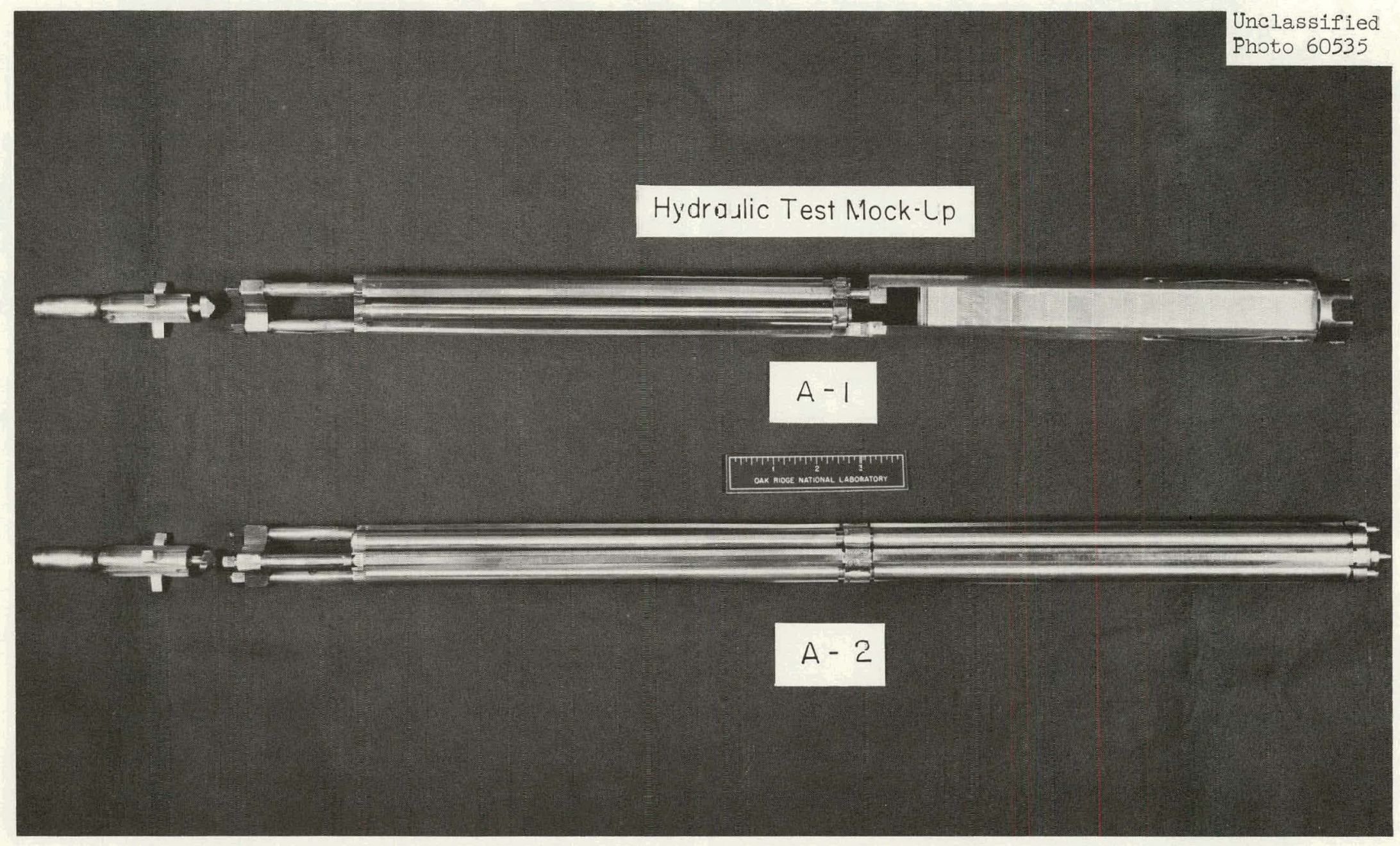

Fis. 45. Army-Martir Stainless Steel Dummy Fuel Spəcimers. 


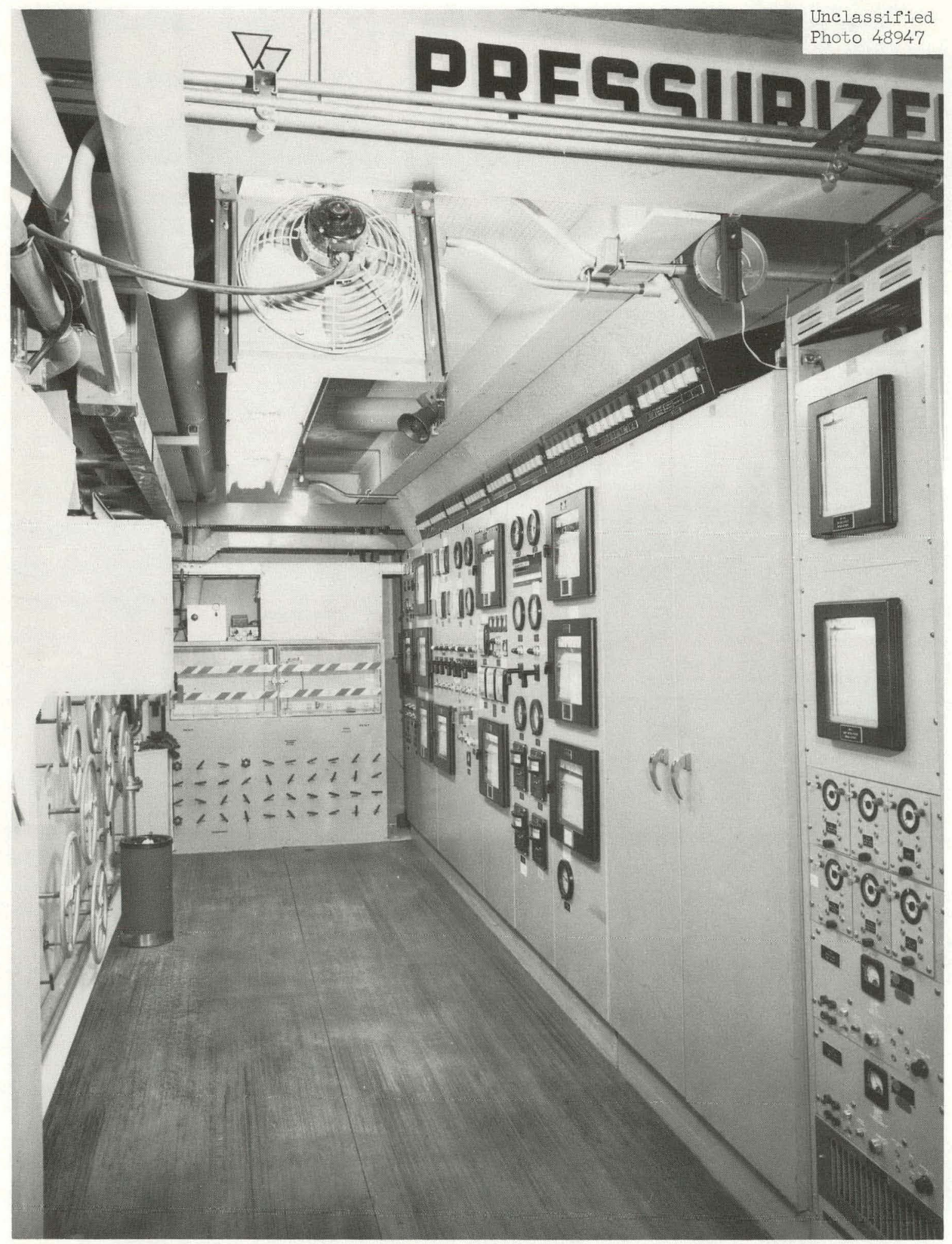

Fig. 46. Operating Area for ORR Pressurized-Water Loop. Control valve handles at left, instrument panel at right, and water sampling station in background. 
working tolerance levels at shutdown and have not exceeded $75 \mathrm{mr} / \mathrm{hr}$ during operation. The sample station area also is kept free from contamination by good sampling techniques.

Low leakage rates and excellent performance of the loop make possible carefully controlled water-chemistry experiments of long duration. Several experiments with water purification have been conducted, particularly with Magnetite filters for removing crud, and improved analytical techniques for water-chemistry measurements have been developed. The water chemistry program objective is development of improved equipment for the removal of impurities at concentrations less than 1 ppm.

A fixture has been provided in which a fuel specimen assembly irradiated in the loop can be removed from its support conduit for examination. The element can be rotated in two planes while in the fixture to provide for viewing and photographing of exposed surfaces through a periscope. Following examination, the assembly can be reattached to the support and reinserted in the loop for further irradiation. Should the element condition have deteriorated so that further irradiation is not desirable, it can be transferred from the fixture to the ORR hot cell. A photograph of the device is shown in Fig. 47.

Fuel tests presently under way are in support of the standard package, PM, Army reactor development with fuel specimens provided by the Martin Company Nuclear Division. ${ }^{32}$ A summary of fuel elements and test conditions for experiments conducted in the loop is given in Table 6 .

\section{MIIR Capsules and Loop Equipment}

The MIR fuel irrudiation test facility was originally developed to operate molten-salt loops for the Aircraft Nuclear Propulsion Program and later for the Molten-Salt Reactor Program, ${ }^{33}$ and it has since been modified to accommodate irradiation capsules of various types. ${ }^{34,35}$ The 6-in. beam hole at the MTR provides considerable volume at a rather high thermal-neutron flux, $1 \times 10^{14}$ neutrons $/ \mathrm{cm}^{2} \cdot \mathrm{sec}$. The high flux and the conveniences offered by the equipment installed facilitate testing a wide variety of fuel types and configurations.

\section{MITR Loops}

The loops as initially installed were compact forced-circulation units for obtaining corrosion data applicable to molten-salt reactors. They were designed to operate in the MTR (IB-3) beam hole. Several tests were conducted with two fused-salt mixtures ( $\mathrm{NaF}-\mathrm{ZrF}_{4}-\mathrm{UF}_{4}$ and $\mathrm{Li}^{7}-\mathrm{BeF}_{2}-\mathrm{UF}_{4}$ ) in loops constructed, respectively, of Inconel and INOR-8 (nominal composition: $70 \% \mathrm{Ni}, 16 \% \mathrm{Mo}$, $7 \% \mathrm{Co}, 5 \% \mathrm{Fe}$, $2 \%$ other alloying elements). The conditions for the se tests are presented in Table 7 . Each loop contained a pump to circulate the molten salt through a hairpin-shaped length 


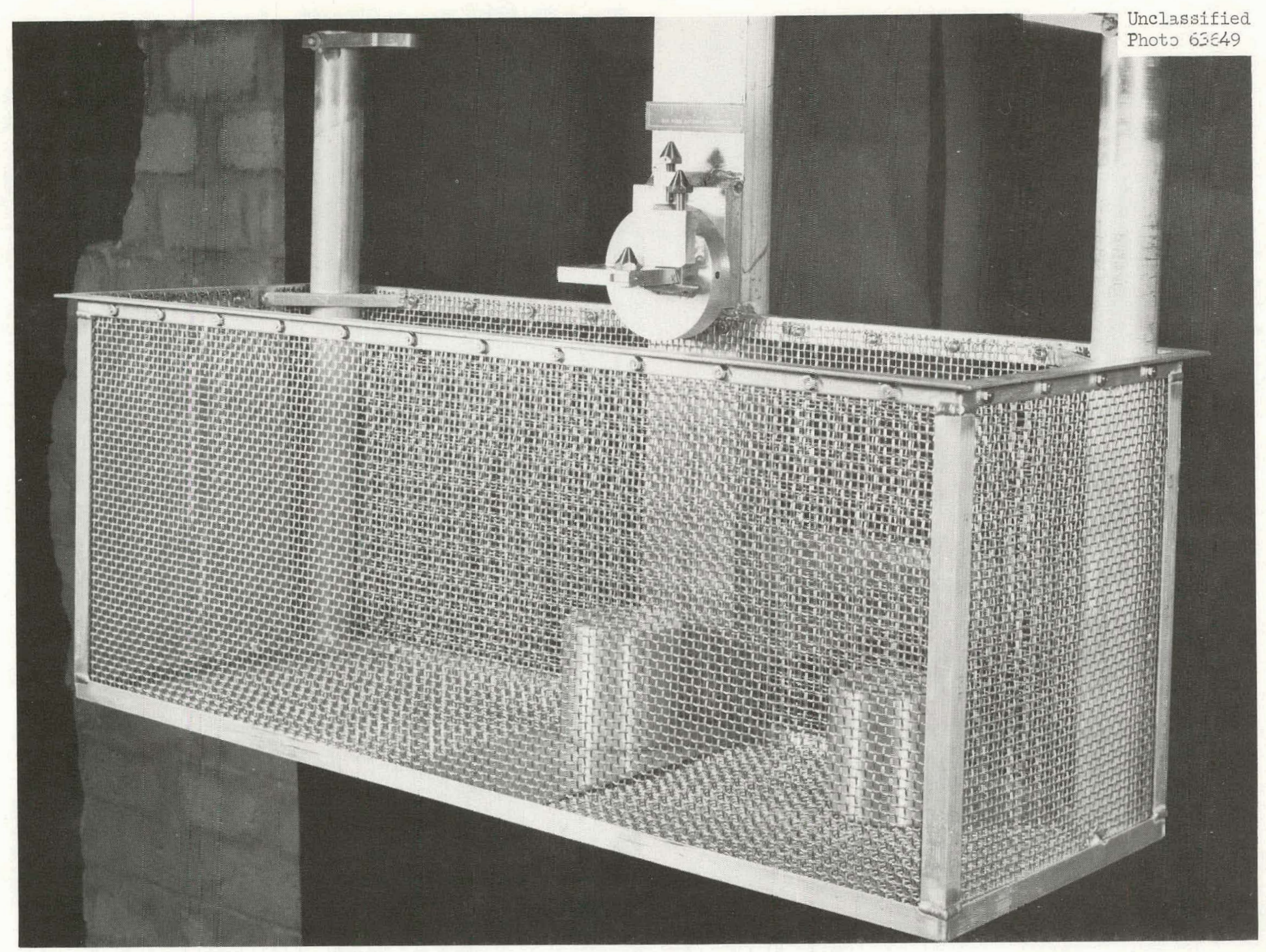

Fig. 47. Fixture for Lnderwater Examinatior of Fuel Elenents from the Pressurized-Nater Lco:. 
Table 6. Experiments Conducted in the ORR Pressurized-Water Loop

\begin{tabular}{|c|c|c|c|c|c|c|}
\hline $\begin{array}{l}\text { Test } \\
\text { No. }\end{array}$ & Fuel Element Description & $\begin{array}{l}\text { Number } \\
\text { of } \\
\text { Ellements }\end{array}$ & $\begin{array}{c}\text { Maximum } \\
\text { Power } \\
\left(\mathrm{Btu} / \mathrm{hr} \cdot \mathrm{ft} \mathrm{t}^{2}\right)\end{array}$ & $\begin{array}{l}\text { Loop } \\
\text { Total } \\
\text { Powera } \\
(\mathrm{kw})\end{array}$ & $\begin{array}{l}\text { Water } \\
\text { Temperature } \\
\left({ }^{\circ} \mathrm{F}\right)\end{array}$ & $\begin{array}{l}\text { Water } \\
\text { Pressure } \\
\text { (psia) }\end{array}$ \\
\hline & & & $\times 10^{3}$ & & & \\
\hline IAI & Swaged $\mathrm{UO}_{2}$, stainless steel clad. & 3 & 95 & 40 & 517 & 1750 \\
\hline $1 \mathrm{~A} 2$ & Swaged. $\mathrm{UO}_{2}$, stainless steel clad & 3 & 115 & 40 & 517 & 1750 \\
\hline 3 & Swaged $\mathrm{UO}_{2}$, stainless steel clad & 6 & 120 & 40 & 500 & 1750 \\
\hline 4 & $\begin{array}{l}\text { Swaged and vibration-compacted } \mathrm{UO}_{2} \text {, } \\
\text { stainless steel clad. }\end{array}$ & 3 & 275 & 110 & 500 & 1750 \\
\hline 5 & $\begin{array}{l}\text { Swaged and vibration-compacted } \mathrm{UO}_{2} \text {, } \\
\text { stainless steel clad. }\end{array}$ & 3 & 275 & 110 & 500 & 1750 \\
\hline 6 & $\begin{array}{l}\text { Vibration-compacted } \mathrm{UO}_{2} \text {, stainless } \\
\text { steel clad. }\end{array}$ & 3 & 400 & 130 & 500 & 1750 \\
\hline 7 & $\begin{array}{l}\text { Vibration-compacted } \mathrm{UO}_{2} \text {, stainless } \\
\text { steel clad. }\end{array}$ & 3 & 550 & 110 & 480 & 1750 \\
\hline 8 & $\begin{array}{l}\text { Vibration-compacted } \mathrm{UO}_{2} \text {, stainless } \\
\text { steel clad. }\end{array}$ & 3 & 425 & 110 & 480 & 1750 \\
\hline 9 & $\begin{array}{l}\mathrm{UO}_{2} \text { pellets in thin stainless steel } \\
\text { cladding (collapsing) }\end{array}$ & 3 & 270 & 110 & 480 & 1750 \\
\hline $\mathrm{L}-1$ & $\begin{array}{l}\text { Vibration-compactec. } \mathrm{ThO}_{2}-\mathrm{UO}_{2} \text {, stain- } \\
\text { less steel clad. }\end{array}$ & 3 & 400 & 110 & 480 & 1750 \\
\hline $\mathrm{PM}-\mathrm{A} I-1$ & $\begin{array}{l}\text { Stainless steel- } \mathrm{UO}_{2} \text { dispersion tubes } \\
\text { and coupons }\end{array}$ & 27 & 800 & 50 & 355 & 1300 \\
\hline $\mathrm{PM}-\mathrm{A} 2-1$ & Stainless steel- $\mathrm{UO}_{2}$ dispersion tubes & 6 & 1200 & 200 & 355 & 1300 \\
\hline
\end{tabular}

Maximum total heat removed by loos during irradiation of fuel element. 
Table 7. In-Pile Loop Tests of Circulating-Molten-Salt Fuel

\begin{tabular}{lccccc}
\hline $\begin{array}{l}\text { Loop } \\
\text { No. }\end{array}$ & $\begin{array}{c}\text { Container } \\
\text { Material }\end{array}$ & $\begin{array}{c}\text { Fused } \\
\text { Salt Fuel } \\
\text { Designation }\end{array}$ & $\begin{array}{c}\text { Maximum } \\
\text { Temperature } \\
\left({ }^{\circ} \mathrm{F}\right)\end{array}$ & $\begin{array}{c}\text { Average } \\
\text { Power } \\
\text { Density } \\
\left(\mathrm{w} / \mathrm{cm}^{3}\right)\end{array}$ & $\begin{array}{c}\text { Total } \\
\text { Fission } \\
\text { Power } \\
(\mathrm{kw})\end{array}$ \\
\hline 3 & Inconel & $44^{\mathrm{b}}$ & 1500 & 200 & 27 \\
4 & Inconel & 44 & 1500 & 232 & 31 \\
6 & Inconel & 44 & 1600 & 250 & 34 \\
7 & INOR-8 & $130^{\mathrm{c}}$ & 1300 & 66 & 9 \\
8 & INOR-8 & 130 & 1300 & 66 & 9 \\
\hline
\end{tabular}

Total loop heat generation divided by total circulating fuel inventory.

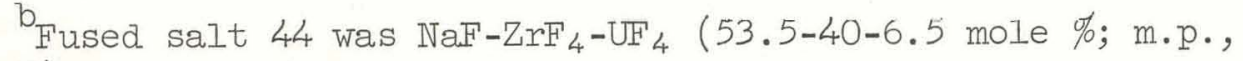
$\left.1000^{\circ} \mathrm{F}\right)$.

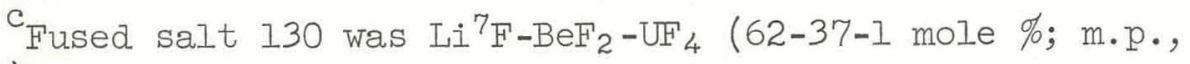
$\left.860^{\circ} \mathrm{F}\right)$.

of $1 / 8-i n$. sched.-40 pipe, as shown in the isometric drawing of Fig. 48 . The pipe was coiled at the forward high-flux end to increase the integrated neutron exposure. A schematic flow diagram for one of the loops is given in Fig. 49. The regenerative turbine-type pump shown in Fig. 50 was developed specifically for this loop. The sump behind the impeller accommodated leakage along the shaft, provided a fluid expansion volume, and afforded the free surface from which fission gases were released to the purge system. A special heat exchanger and other items of equipment were also designed for use in these loops. An overall view of the test facility as used for loops is shown in Fig. 51.

Although the cquipment for loop operation is no longer intact, many of the components have been retained. The facility presently affurds electrical heating for capsules, gas purging, water cooling, monitoring of effluent lines for radioactivity, large charcoal traps for accumulation of fission gases, sampling stations, and extensive instrumentation. Convenient mechanisms have been provided for installation of test assemblies in the beam hole and for mechanical adjustment of the specimen position in the beam hole during reactor operation to obtain the desired flux for the experimental fuel within the gradient available.

Photographs showing loops in various stages of construction are presented in Figs. 52 through 56. Equipment for removing large volumes of helium purge gas for analysis of chemical impurities and fission-product gases is shown in Fig. 57. The instrument panel used for both loop and capsule tests is shown in Fig. 58. 
OUTER WATER JACKET

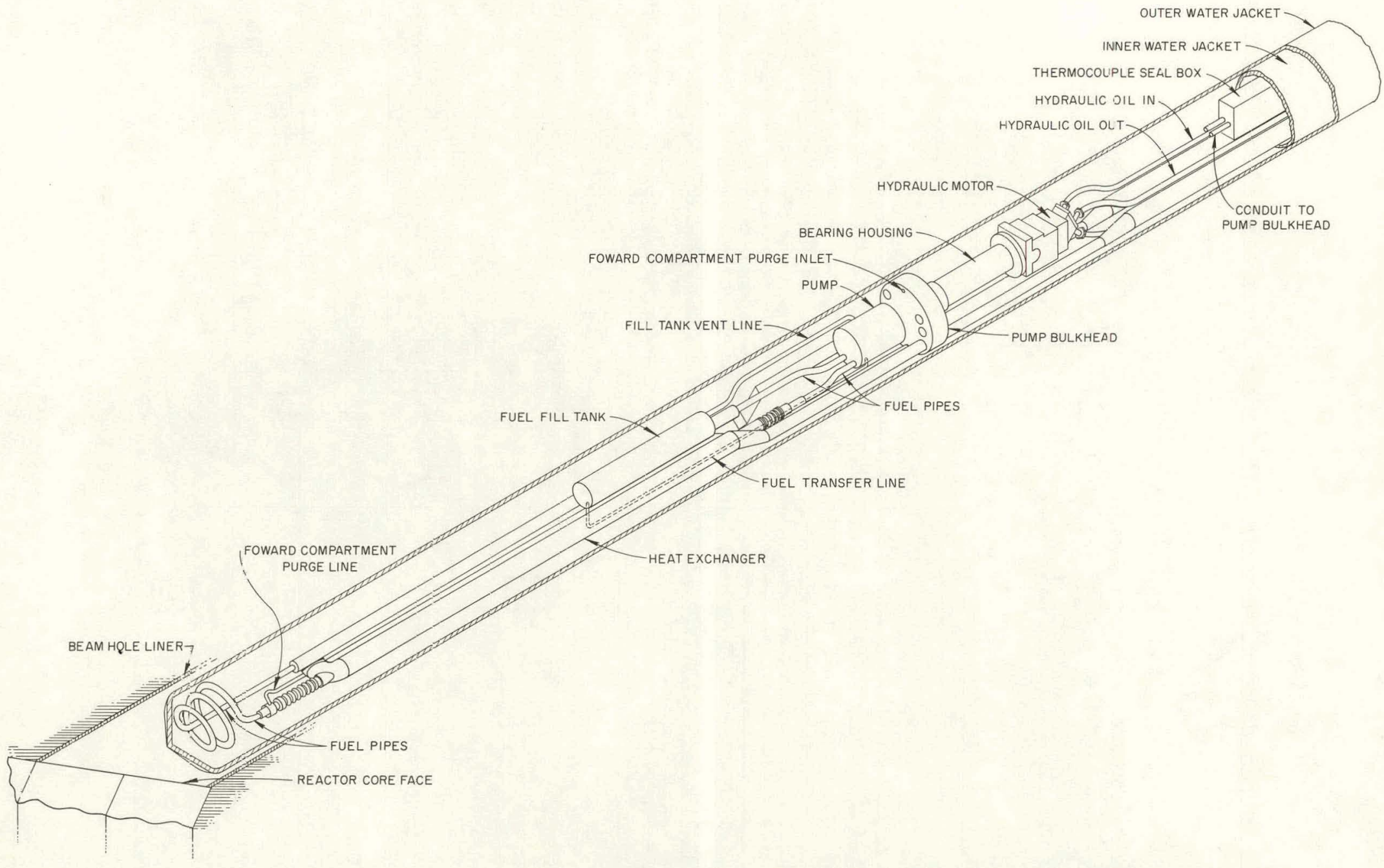

Fig. 48. Diagram of Circulating-Fused-Salt Fuel Irradiation Test Lcכp. 


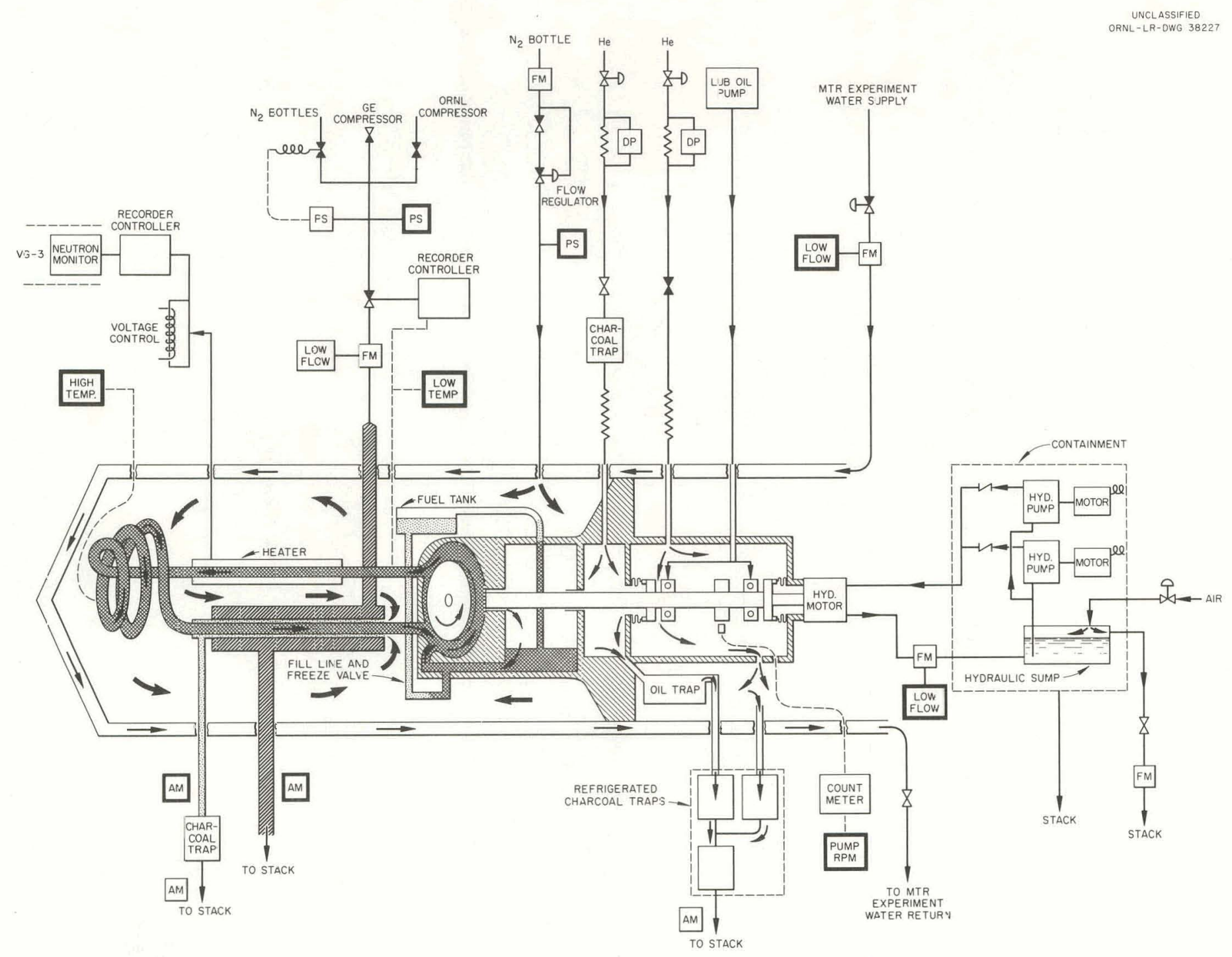

Fig. 49. Flow Diagram for ORNL-MTR-44 Circulating-Fused-Salt Fuel Irraciation Test Loop. 


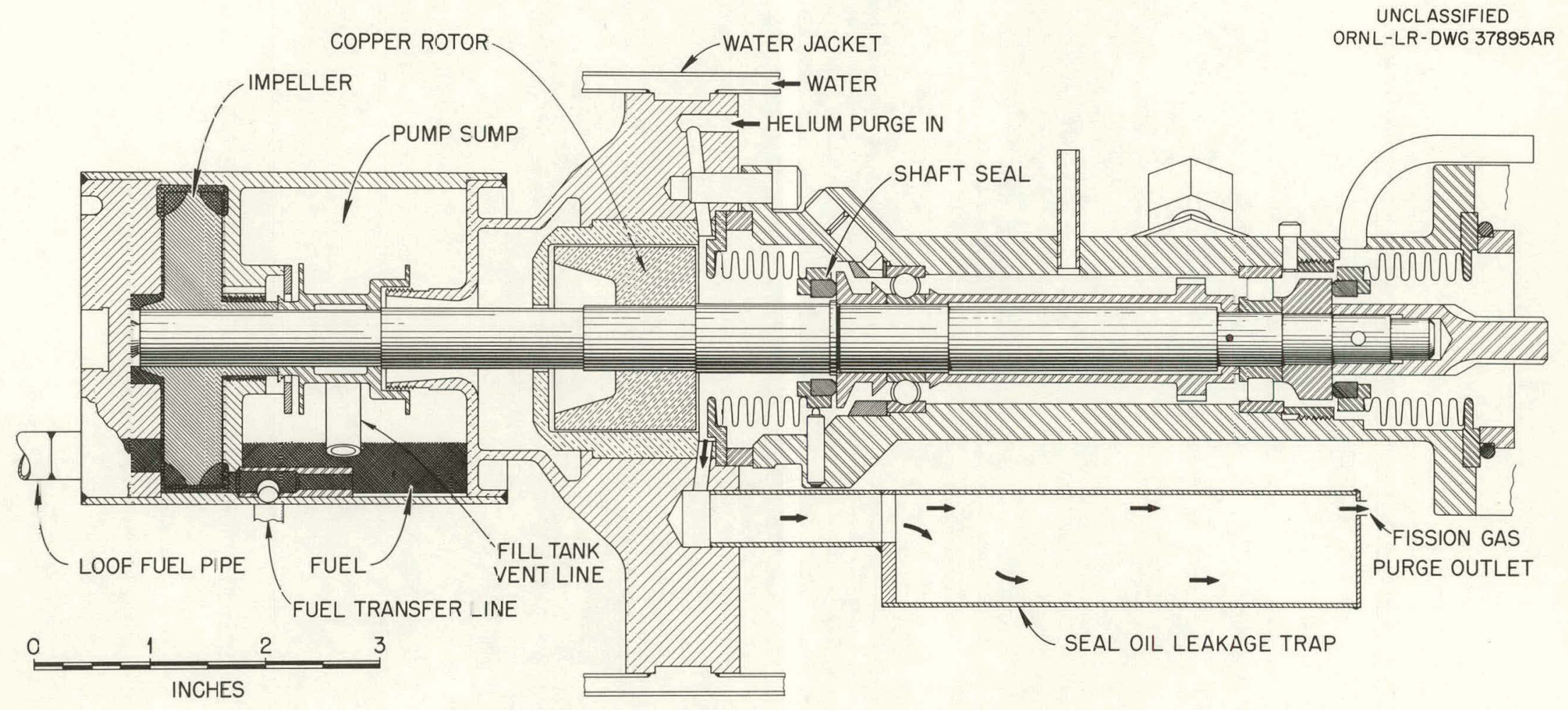

Fig. 50. Fuel Pump for Fused-Salt In-Pile Lcop. 


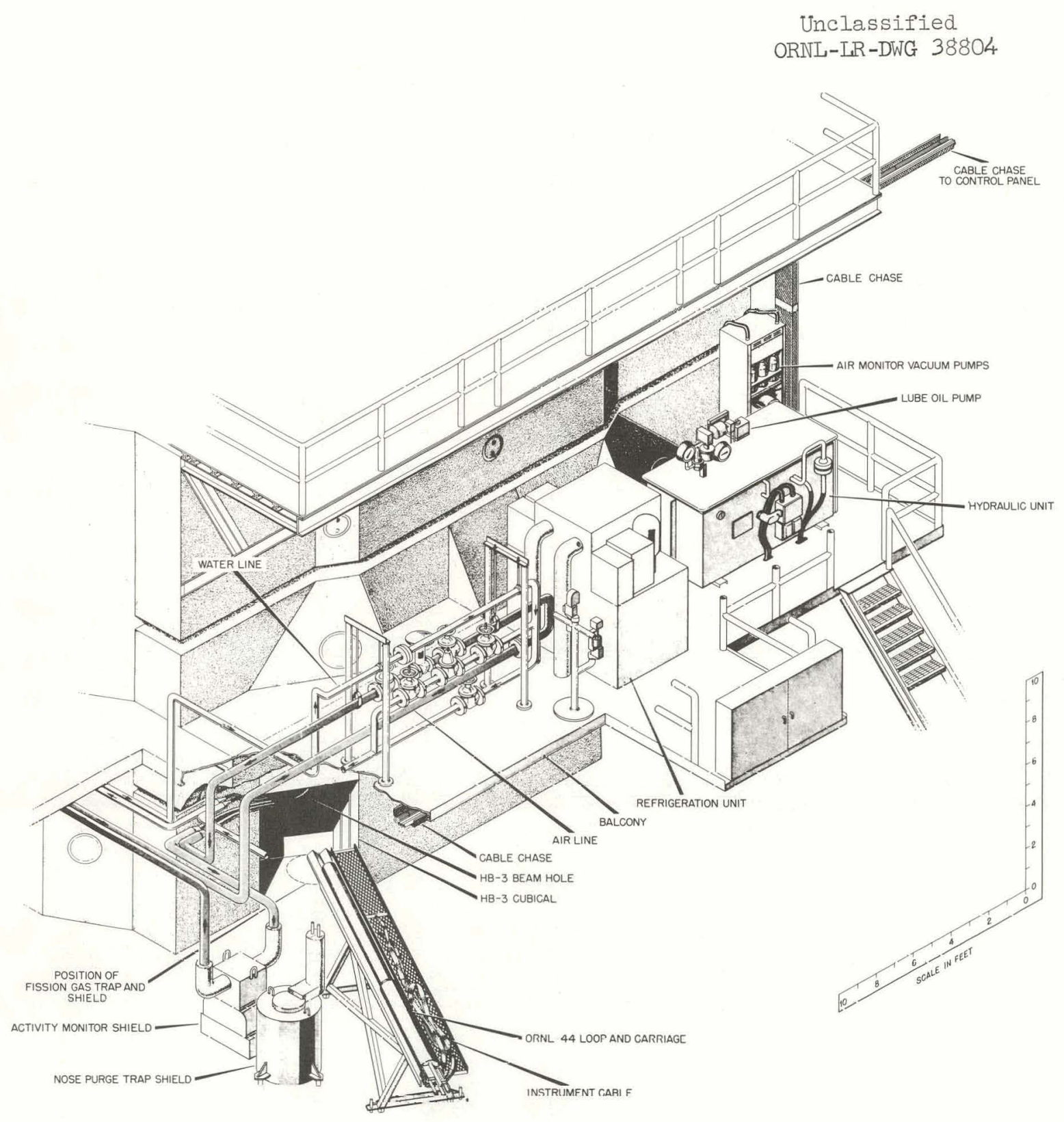

Fig. 51. Irradiation Facility at the MTR HB-3 Beam Hole. 


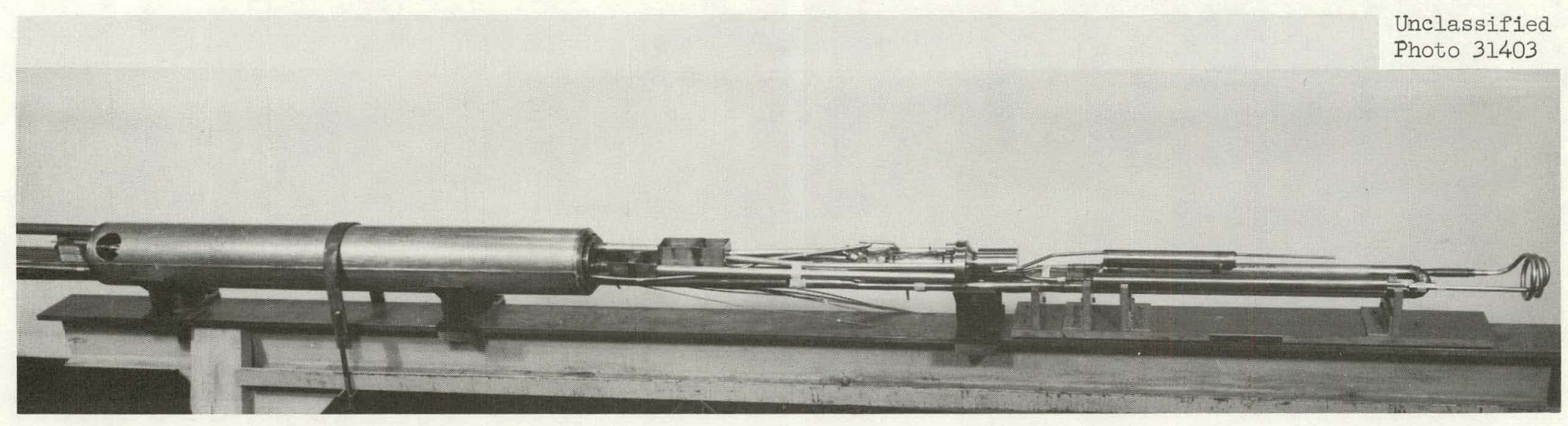

Fig. 52. Overall View of Molten-Salt Loop with Shielciing Plug Attached. 


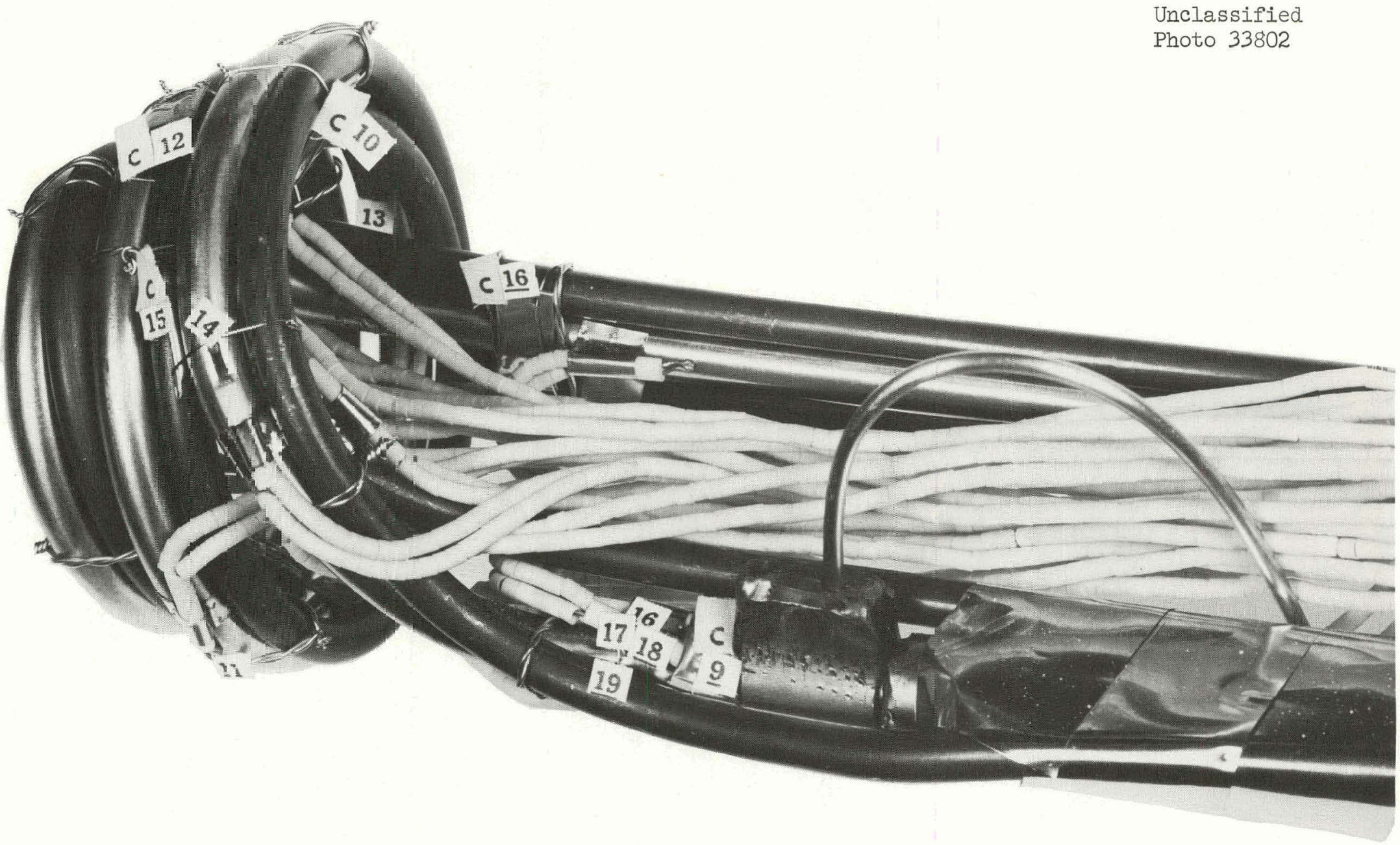

Fig. 53. Closeup of Molten-Salt Loop Nose Coil with Heaters Installed and Thermocourlas Attached. 


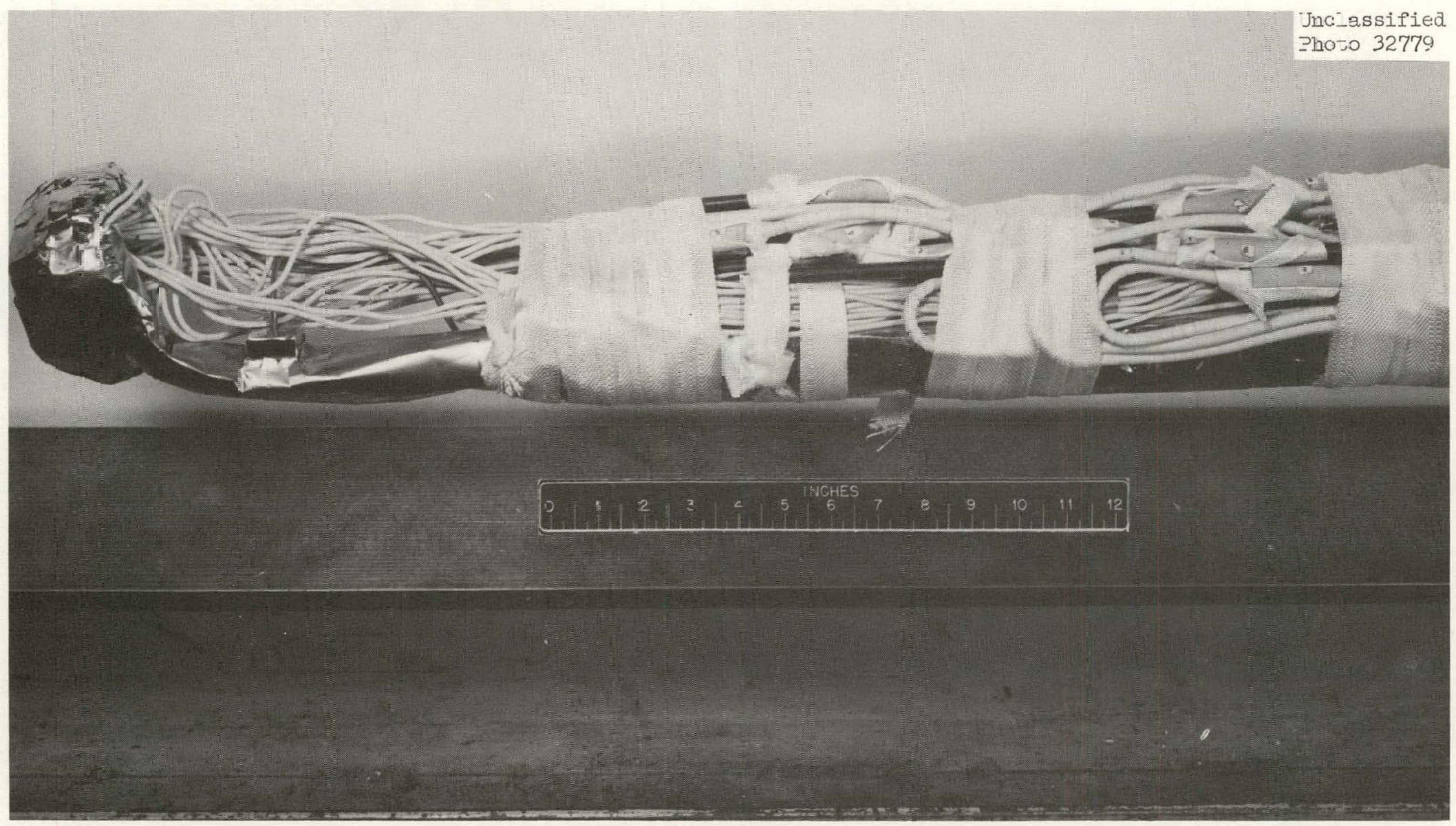

Fig. 54. Forward End of Nolten-Salt Joop as Assembled W:thout Water Jaciet. 


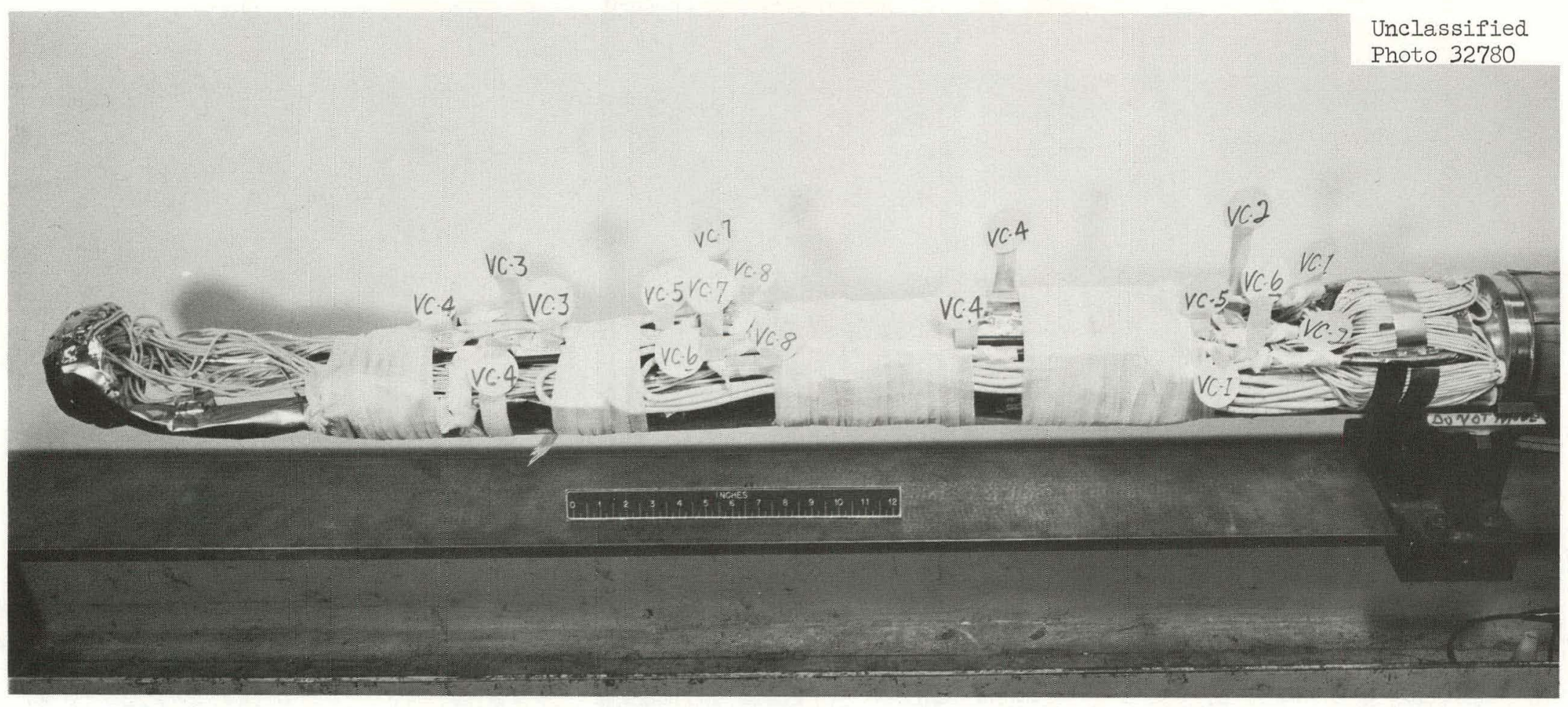

Fig. 55. Overall View of Molten-Salt Loop Assembly Without Water Jacket. 


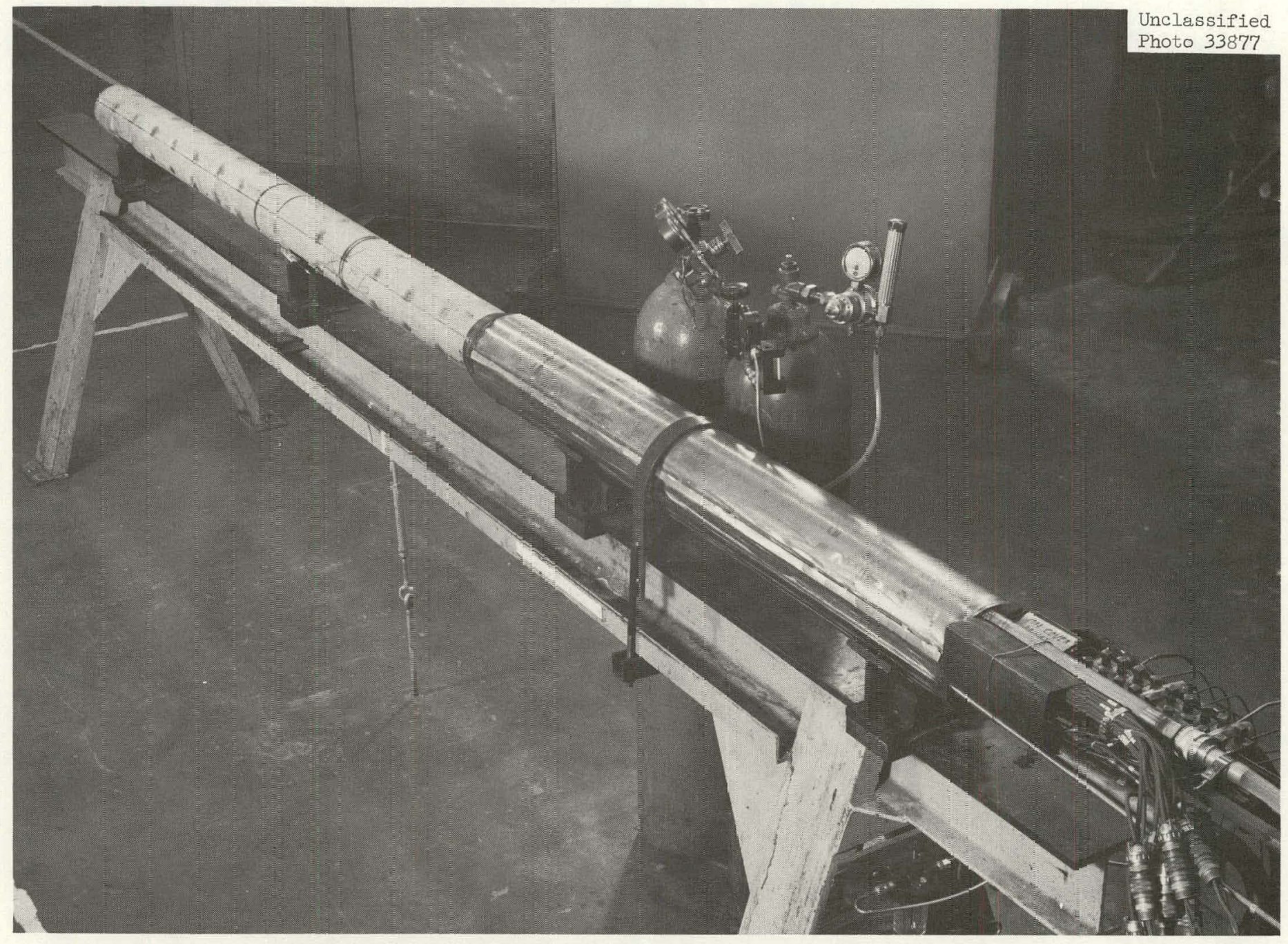

Fig. 56. Completed volten-Salt Locp on Assembly Fixture. The ou-er surface configurations of keam hole irradiation assemblies for molten-salt capsules and fueleä-graphite carsules „re iden-ical except, for details of ccolant anz instrument lines at the rear. 


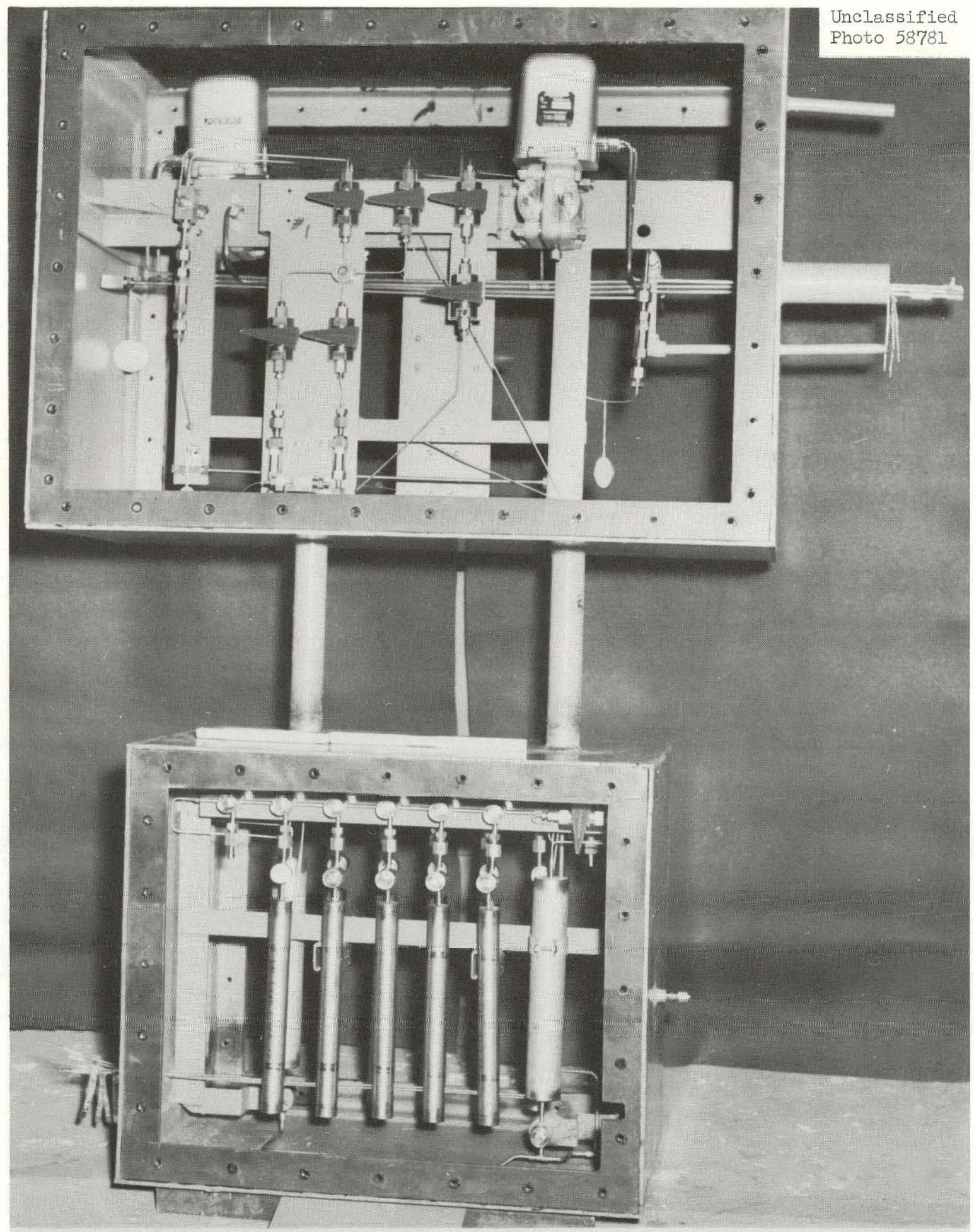

Fig. 57. Sampling Station for Removal of Large Bottles of Radioactive Gas for Chemical Analysis. 


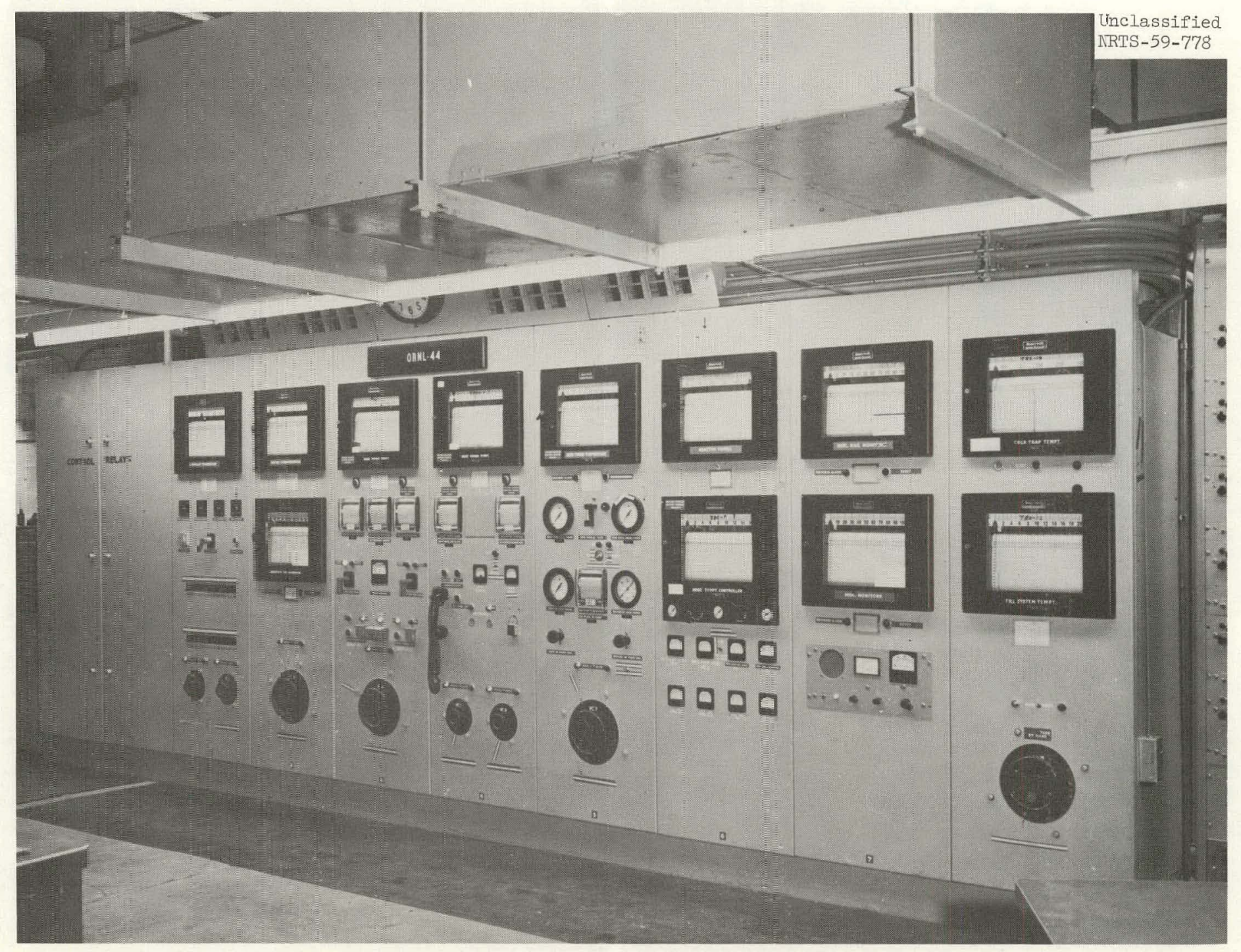

Iig. 58. Instrument Panel for MTR Fezility. 
Molten-Salt Capsules

Recently the MIR facility has been used for irradiation of moltensalt capsules to determine the chemical compatibility of graphite with the salt in INOR-8 containers. From four to six capsules, each $1 / 2$ to 1 in. in diameter, can be irradiated in a vessel that is sodium-filled. for convenience in heat removal. The sodium also affords temperature stability and a bath in which temperature measurements can be made using thermocouples without attachment to the capsule. One capsule assembly is shown in the photograph of Fig. 59. The sectional view of Fig. 60 shows a capsule in which graphite is kept immersed in liquid fuel during irradiation. Provision is made for purging the capsules with helium to carry gaseous products to a sampling station, where they can be removed. for analysis.

Temperature control is achieved by changing the thermal resistance between the axially movable sodium tank and the beam-hole water-jacket liner, which have slightly tapering concentric surfaces, to form a gas gap of variable thickness. The overall assembly, shown in Fig. 61, is movable in the beam hole to utilize the flux gradient for control of the irradiation exposure.

Studies of chemical reactions, such as the formation of small quantities of $\mathrm{CF}_{4}$, as well as released fission gases, have been made both during irradiation and in postirradiation examination. Molten-saltfueled capsule irradiations conducted in the MTR facility and described in Table 8 have shown the combinations of salt, fuel, and graphite for the $\mathrm{MSRE}^{36}$ to be compatible at the reactor design conditions.

A capsule design now under development will provide for recirculation of the purge gas to determine equilibrium concentrations of reaction products. Copper blocks that fit closely around the fuel container replace the NaK vessel. Electrical heaters imbedded in the copper will keep the salt molten during reactor shutdown periods.

\section{Fueled-Graphite Capsules}

A second modification of the facility has been made in order to irradiate relatively large specimens of fueled graphite. It was desired. to determine the stability of $\mathrm{UC}_{2}$ fuel in a graphite matrix operating at high temperatures and high power densities. Also studied was the performance of sealed low-permeability cans as devices for retaining fission gases. 37

An overall view of the assembly for these experiments is shown in Fig. 62. The rig containing the graphite specimen is separate from the beam-hole shield and cooling jacket, so only a relatively simple structure needs to be fabricated for each irradiation. One typical assembly is shown in Fig. 63. Neutron flux control is by movement of the assembly in the beam hole. Independent temperature variation and control are not 
Table 8. Molten-Salt-Fuel Irradiation Tests

\begin{tabular}{|c|c|c|c|c|c|}
\hline $\begin{array}{l}\text { Test } \\
\text { Number }\end{array}$ & Capsule Ilescription & $\begin{array}{l}\text { Number } \\
\text { of } \\
\text { Capsules }\end{array}$ & $\begin{array}{l}\text { Temperature } \\
\qquad\left({ }^{\circ} \mathrm{F}\right)\end{array}$ & $\begin{array}{l}\text { Power } \\
\text { Density } \\
\left(\mathrm{w} / \mathrm{cm}^{3}\right)\end{array}$ & $\begin{array}{c}\text { Total } \\
\text { Fission } \\
\text { Power } \\
\text { (kw) }\end{array}$ \\
\hline $47-1$ & $\begin{array}{l}\text { Inconel bellows; graphite submerged in fuel } \\
\text { under } 100 \text { psi }\end{array}$ & 4 & 1300 & 200 & 12 \\
\hline $47-2$ & $\begin{array}{l}\text { INOR-8 bellows; graphite submerged in fuel } \\
\text { under } 100 \text { psi }\end{array}$ & 4 & 1300 & 200 & 12 \\
\hline $47-3$ & $\begin{array}{l}\text { Graphite crucible containing fuel and ma- } \\
\text { terials specimens }\end{array}$ & 4 & 1750 & 200 & 6 \\
\hline \multirow[t]{2}{*}{$47-4$} & Submerged graphite cylinder & 4 & 1400 & 65 & \multirow{2}{*}{4} \\
\hline & Small graphite crucible containing fuel & 2 & 1320,1650 & 55,130 & \\
\hline \multirow[t]{2}{*}{$47-5$} & $\begin{array}{l}\text { Submerged graphite cylinder (two capsules } \\
\text { purged) }\end{array}$ & 4 & 1300 & 35,65 & \multirow[t]{2}{*}{2.8} \\
\hline & Graphite specimens impregnated with fuel & 2 & & $2,6^{a}$ & \\
\hline
\end{tabular}

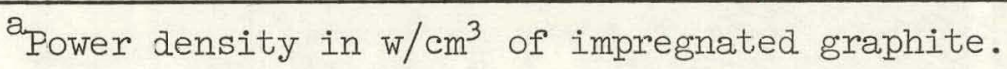




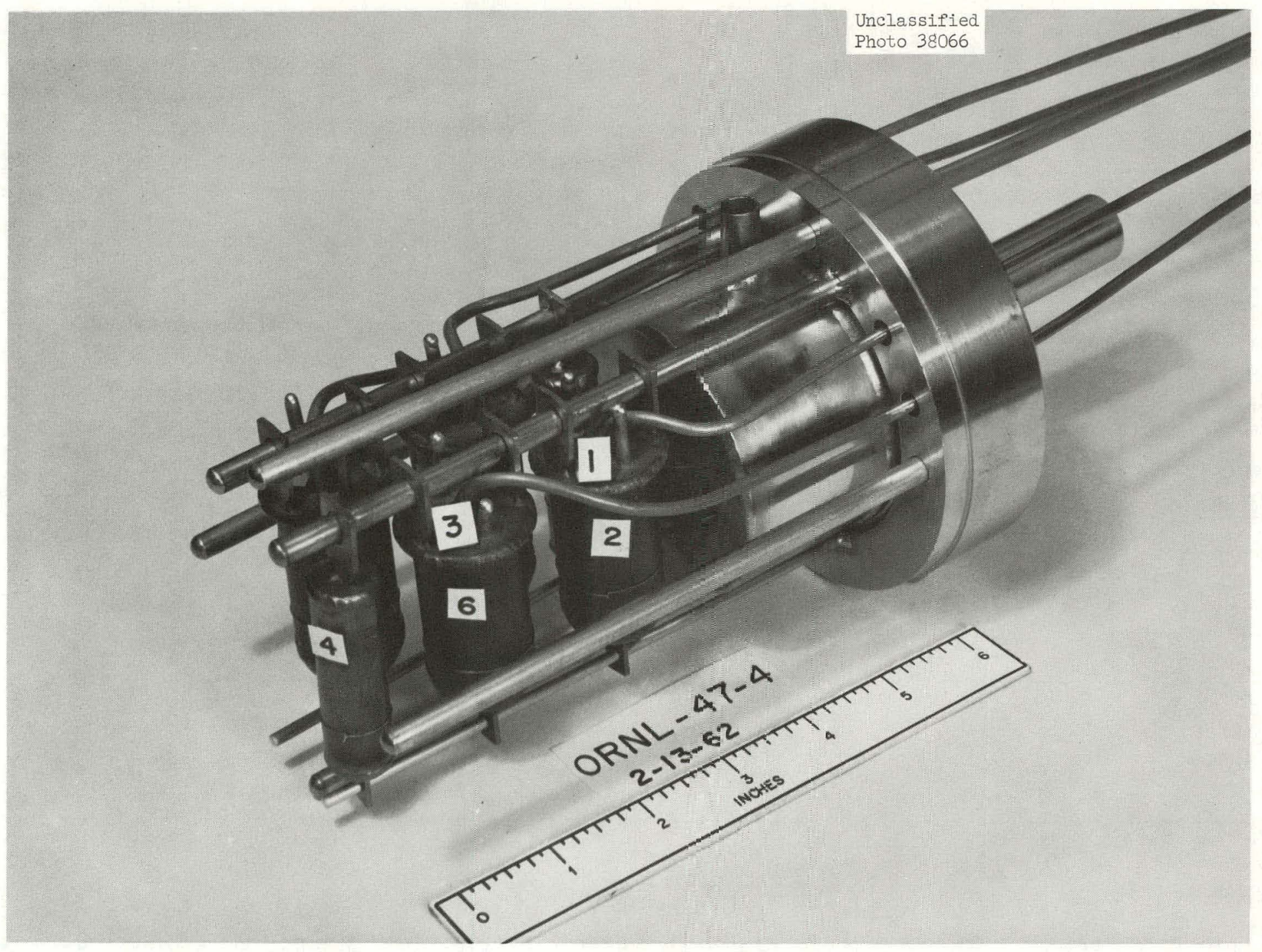

Fig. 59. Assembled Molten-Salt-Fueled Cajsules Prior to Installation in Sodium-Filled Can. 


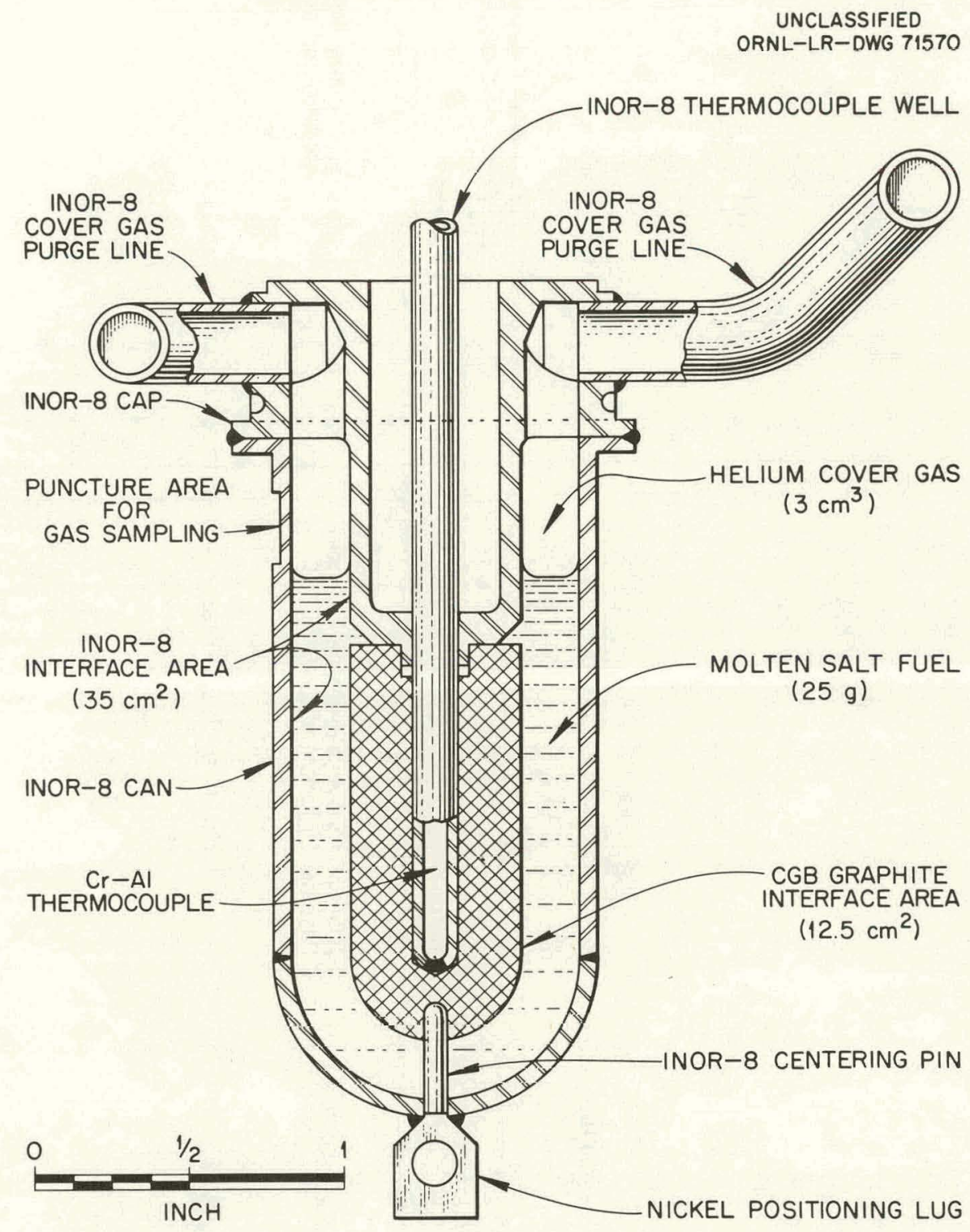

Fig. 60. Purged Capsule Containing Graphite Submerged in MoltenSalt Fuel. 
UNCLASSIFIED ORNL-LR-DWG 69492

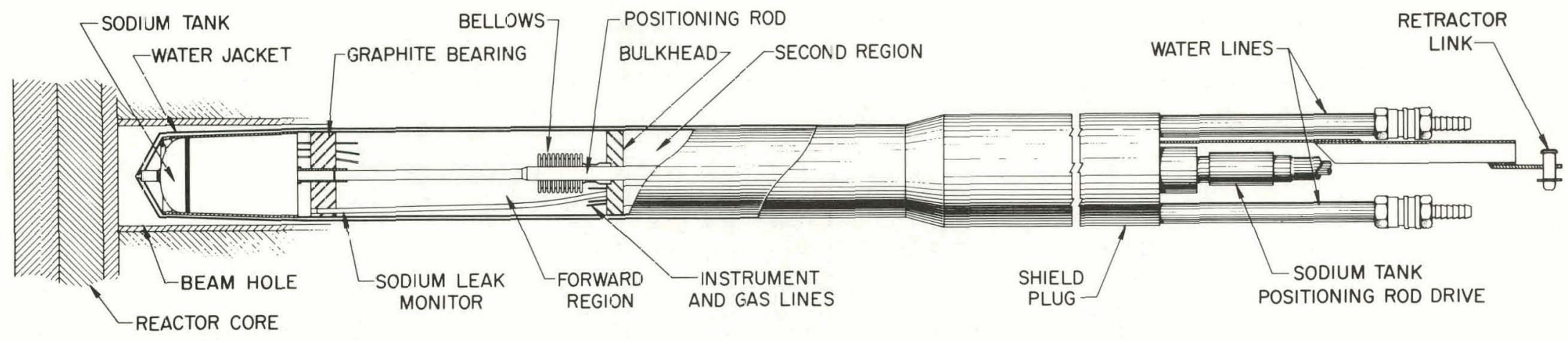

F-g. 61. ORIL-MTR-47-3 Molten-Salt-Fueled Capsule Test Assembly. 


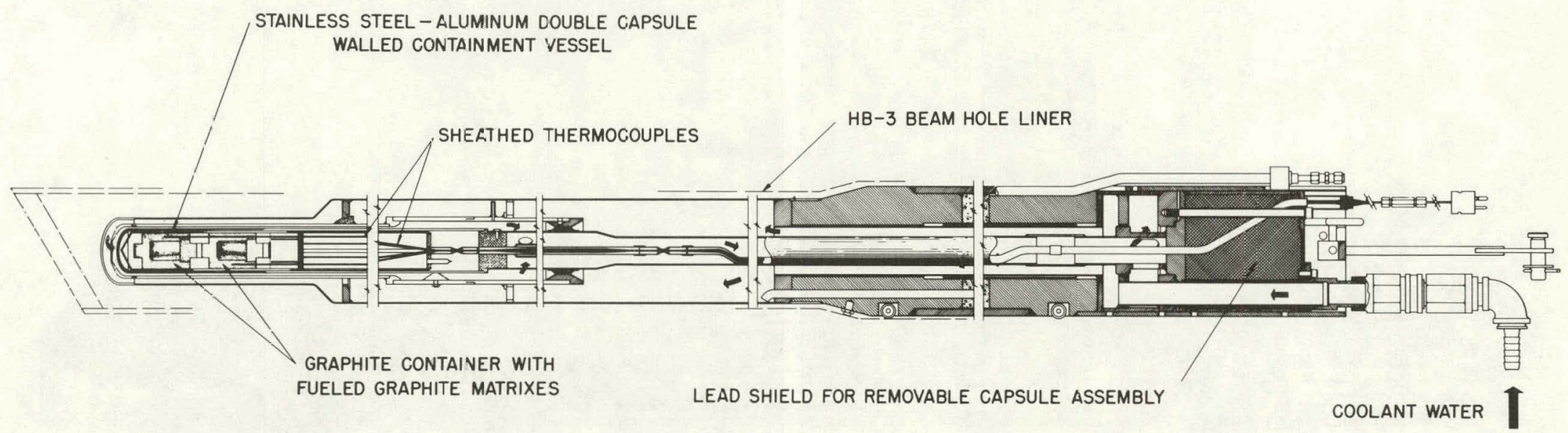

Fig. 62. CRNL-MTR-48 Capsule and Plug Assembly for Advanced GCR FuelElement Irradiation Tests. 


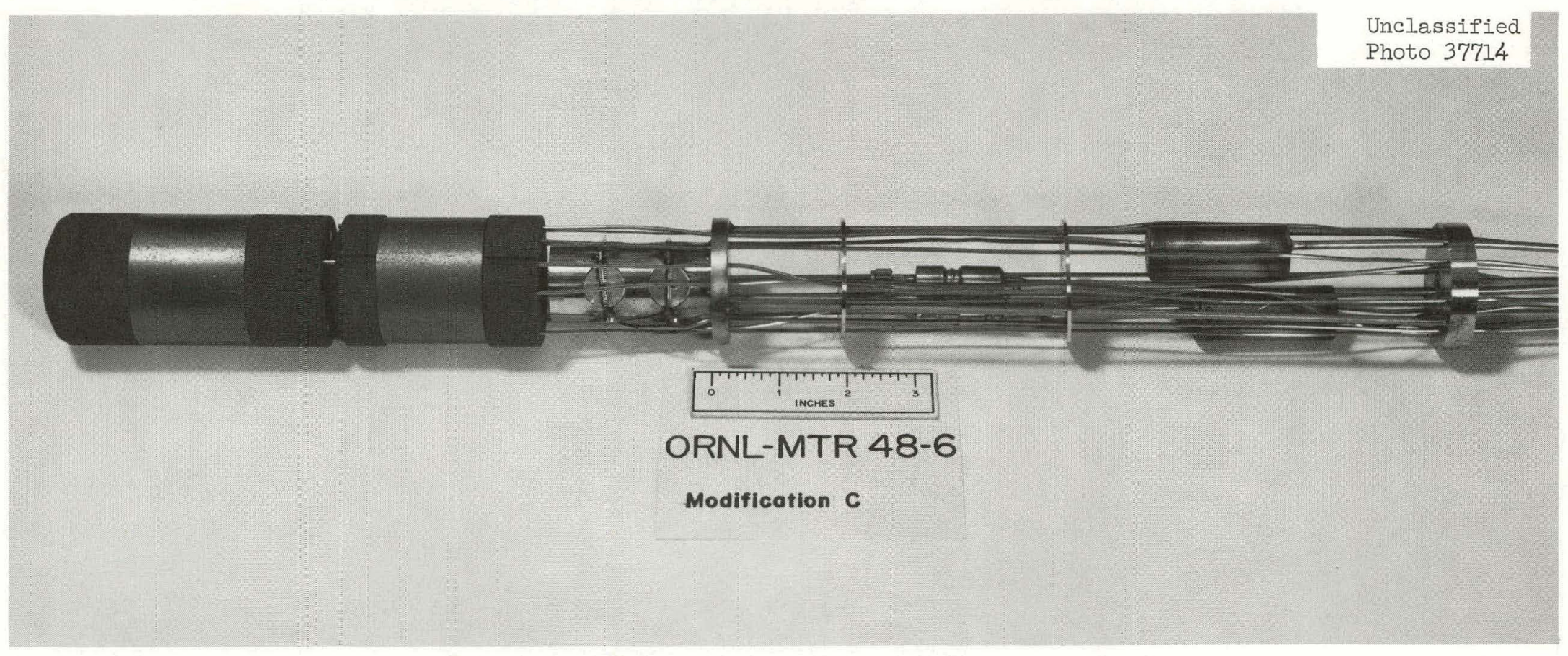

Iig. 63. Assembly for Graphite Matrix Fuel Element and Loose CoatedParticle Irradiation in the MIR Capsule Facility. 
provided, although power adjustment made through variation of flux can be used to establish the desired temperature. The fuel chamber can be purged with helium to remove released fission products to a sampling station where small vials of gas can be removed for analysis by gammaray spectrometry.

Graphite-matrix fuel elements containing either pyrolytic-carboncoated or uncoated uranium carbide particles have been irradiated. Several specimens, including containers of loose coated particles, have been irradiated simultaneously in some assemblies. Limited provision has been made for studies of fission-product deposition as it is affected by surface roughness and chemistry. The tests that have been completed are described in Table 9.

\section{Shop Facilities for Capsule and Loop Assembly}

The degree of success of any reactor fuel irradiation program is determined in large measure by the capability for fabrication of test assemblies. The equipment must meet very high standards of reliability to achieve safety in test reactor operation and to ensure useful results commensurate with the high costs of the materials irradiated and of the neutrons utilized. Furthermore, close tolerances frequently are necessary to achieve the required precision in temperature measurement and. control, in heat removal, determination of flow rates, and other test conditions.

A special shop equipped for assembling capsules and for loop construction is available. This shop is arranged as shown in Fig. 64. It provides for independent assembly of each type of capsule or loop so that several may be in construction simultaneously. Test assemblies manufactured in the shop have varied in size from the small LITR capsules of Fig. 21 to the FGCR instrumented fuel assemblies of Fig. 65, which when completed will be 45 ft long. 38

Special work areas have been provided that are each designed for critical steps or techniques, such as the preparation of thermocouples, welding, cleaning assemblies, evacuating, and dry box work. Much of the work is highly specialized; for example, welding small tungsten vs rhenium thermocouple junctions, filling capsules with liquid metals, and assembling structures in contact with fuel element materials.

Since thermocouples are used as the primary sensors for most irradiation experiments, considerable attention has been paid to techniques for their manufacture. In general, metallic-sheathed swaged thermocouples have been used. For service up to $1700^{\circ} \mathrm{F}$, Chromel-P vs Alumel wires and junctions with $\mathrm{MgO}$ insulation and stainless steel sheathing are standard, and the technology is well known. At higher temperatures, tungsten and rhenium, or alloys of these metals, in particular, $W-5 \%$ Re vs $W-26 \% \operatorname{Re}$, have been used.24,39,40 Beryllium oxide insulation sheathed with tantalum 
Table 9. Fueled-Graphite Capsules Irradiated in the MIR

\begin{tabular}{|c|c|c|c|c|c|c|}
\hline $\begin{array}{l}\text { Experiment } \\
\text { Number }\end{array}$ & Description & $\begin{array}{l}\text { Number } \\
\text { of } \\
\text { Elements }\end{array}$ & $\begin{array}{l}\text { Surface } \\
\text { Temperature } \\
\left({ }^{\circ} \mathrm{F}\right)\end{array}$ & $\begin{array}{l}\text { Central } \\
\text { Temperature } \\
\left({ }^{\circ} \mathrm{F}\right)\end{array}$ & $\begin{array}{l}\text { Power } \\
\text { Density } \\
\left(\mathrm{w} / \mathrm{cm}^{3}\right)\end{array}$ & $\begin{array}{l}\text { Total } \\
\text { Power } \\
(\mathrm{kW})\end{array}$ \\
\hline $48-1$ & $\begin{array}{l}\mathrm{UC}_{2} \text { in graphite matrix encapsulated in } \\
\text { permeable graphi-e }\end{array}$ & 2 & 1600 & $3500^{a}$ & 280 & 10 \\
\hline $48-2$ & $\begin{array}{l}\mathrm{UC}_{2} \text { in graphite matrix encapsulated in } \\
\text { low-permeability graphite }\end{array}$ & 1 & 1500 & $2500^{a}$ & 150 & 3 \\
\hline $48-3$ & $\begin{array}{l}\mathrm{UC}_{2} \text { in graphite matrix encapsulated in } \\
\text { low-permeability graphite } \mathrm{b}\end{array}$ & 1 & 1500 & $3500^{a}$ & 290 & 18 \\
\hline $48-4$ & $\begin{array}{l}\mathrm{UC}_{2} \text { in graphite matrix encapsulated in } \\
\text { low-permeability graphite } \mathrm{b}\end{array}$ & 1 & 1500 & $3500^{a}$ & 280 & 17 \\
\hline $48-5$ & $\begin{array}{l}\text { Pyrolytic-carbon-coated } \mathrm{UC}_{2} \text { particles } \\
\text { in graphite encapsulated in permeable } \\
\text { graphite }\end{array}$ & 1 & 1500 & $2500^{a}$ & 150 & 3 \\
\hline \multirow[t]{2}{*}{$48-6$} & $\begin{array}{l}\text { Pyrolytic-carbon-coated } \mathrm{UC}_{2} \text { particles } \\
\text { in graphite encapsulated in rermeable } \\
\text { graphiteb }\end{array}$ & 1 & 1500 & $2000^{c}$ & 601 & 3 \\
\hline & $\begin{array}{l}\text { Loose pyrolytic-carbon-coated } \mathrm{UC}_{2} \text { par- } \\
\text { ticles in stainless steel tubes }\end{array}$ & 4 & & $1200^{\mathrm{a}}$ & 1500 & \\
\hline
\end{tabular}

${ }^{a}$ Calculated.

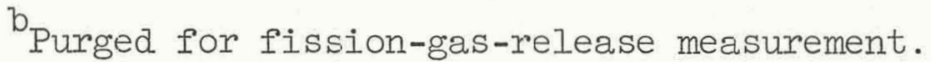

${ }^{c}$ Central temperature was measured using an Inconel-sheathed Pt vs Pt-Rh thermocouple. The Inconel was plated with copper to provide a diffusion barrier to prevent carburization. 


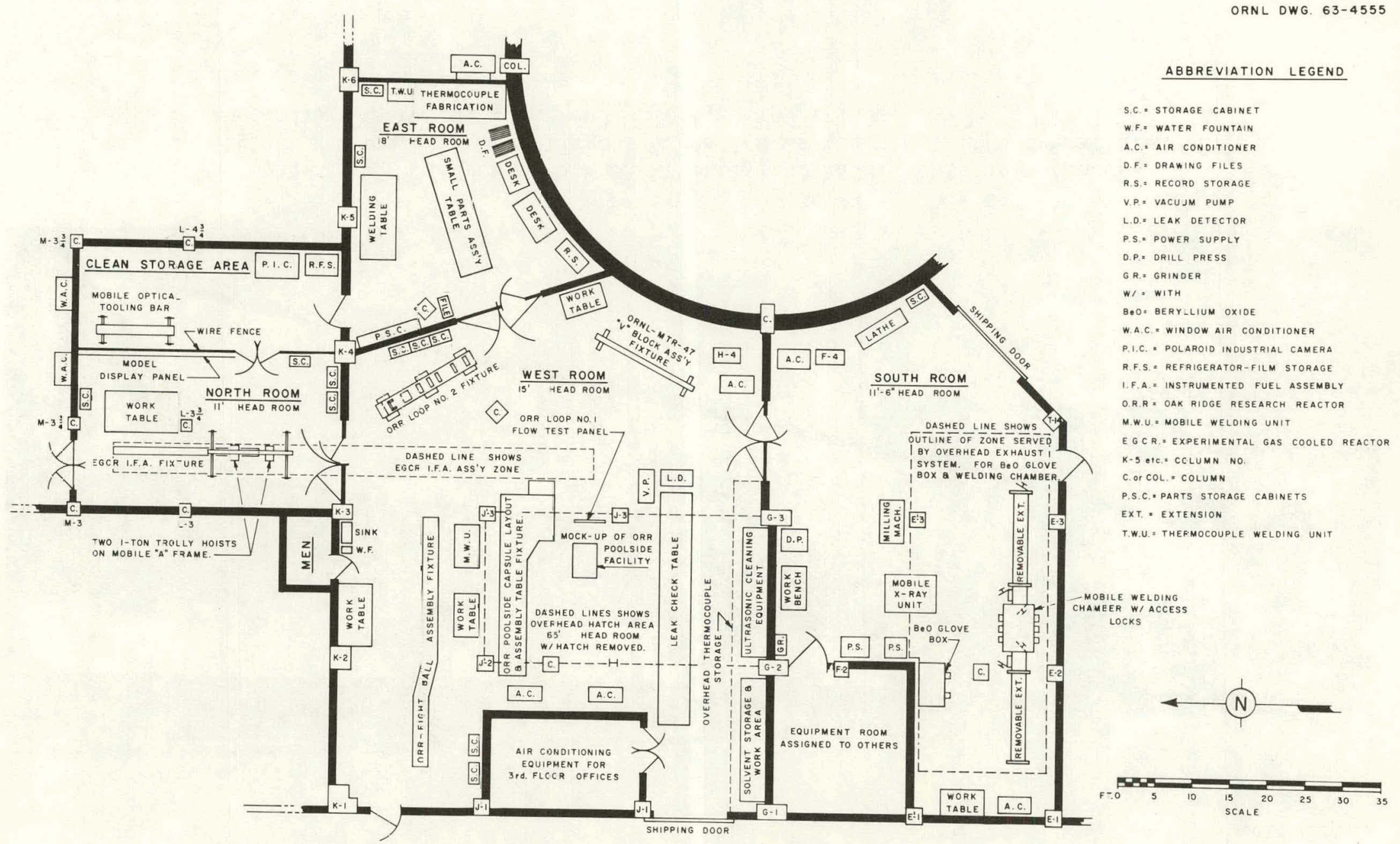

Fig. 64. Plan View of Shop and Assembly Area. 


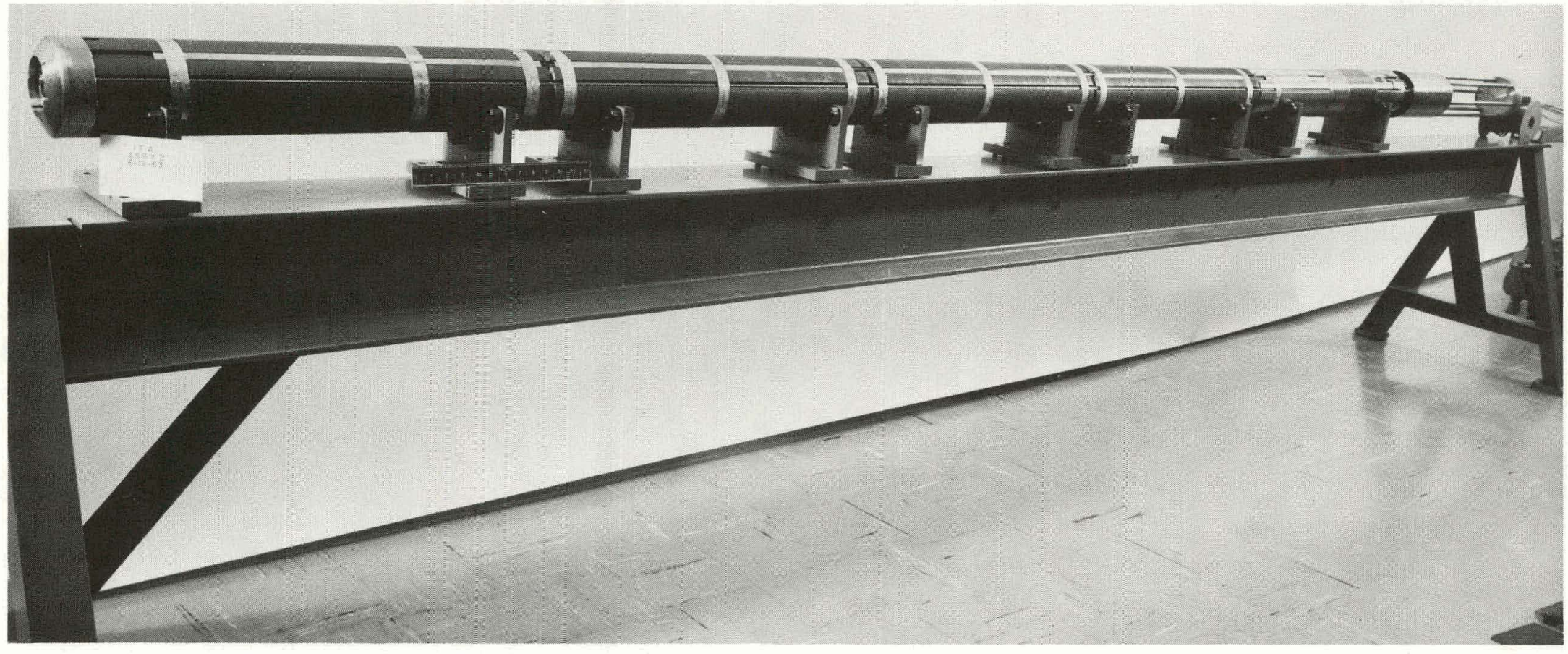

Fig. 65. Instrumented Fuel Assembly Jor EGCR. This unit (shown

r6 ft in length) is the largest assembled in the shop. Its overall length, including instrument leads and shield, is $45 \mathrm{ft}$. 
has been used extensively at temperatures between 2000 and $4400^{\circ} \mathrm{F}$.* For the higher temperature service, insulation with loose fitting beads is preferred. Frequently, the sheath and swaged insulation are removed near the junction and are specially formed for the intended service. Assemblies like that shown in Fig. 66 have given satisfactory service when u.sed with $\mathrm{BeO}$ beads and in molybdenum wells for capsule** and loop experiments.*** The junctions are made by inert-arc welding using a miniature torch with semiautomatic equipment and with magnifying optical systems for viewing.

Cleaning equipment for irradiation equipment parts and assemblies includes tools for air blasting with abrasives, an ultrasonic cleaning bath, high-vacuum pumps, and high-temperature furnaces. Conventional solvents and abrasives are also used. Hydrogen furnaces and specialized. metallurgical facilities are available but are not part of the assembly shop.

Rigid assembly benches with clamping jigs and fixtures are used to establish the outer configuration of each assembly to ensure a suitable fit in the reactor facility. This is highly important, since test reactor structures are relatively light, and impairment of reactor functions, including control rod action, can result from poor fit up. Separate jigs are provided to check the alignment of equipment, especially where several pieces are to be installed in sequence. Optical tooling is employed to establish the alignment of jigs and fixtures and, at times, to inspect finished parts.

Inspection services utilize dye penetrants, helium leak testing, commercial $x$-ray, 1,000,000-volt x-ray, $x$-ray equipment with closed circuit television, isotope irradiation sources, dimensioning tools, including a large surface plate, optical equipment, gas flow metering, and test furnaces. Thermocouple calibration furnaces and associated readout equipment have been provided.

Photographs of specialized shop equipment are shown in Figs. 67 through 74. A highly trained staff of technicians and craftsmen is supervised by a mechanical engineer. Each assembly is built to drawings and specifications following detailed assembly procedures.

Relatively low costs for capsule assemblies are achieved through the use of special tools, careful scheduling of work, including simultaneous construction of several assemblies where possible to better utilize special crafts, and through close supervision of work to minimize rejects. The task engineer for each experimental test rig works closely with the shop supervisor during the assembly of his equipment to ensure its satistactory performance in the test reactor.

\footnotetext{
*See section on "LL'l'R Air-Cooled Capsules."

**See section on "ORR Poolside Capsule Facility."

***See section on "ORR Gas-Cooled Loop No. 1."
} 


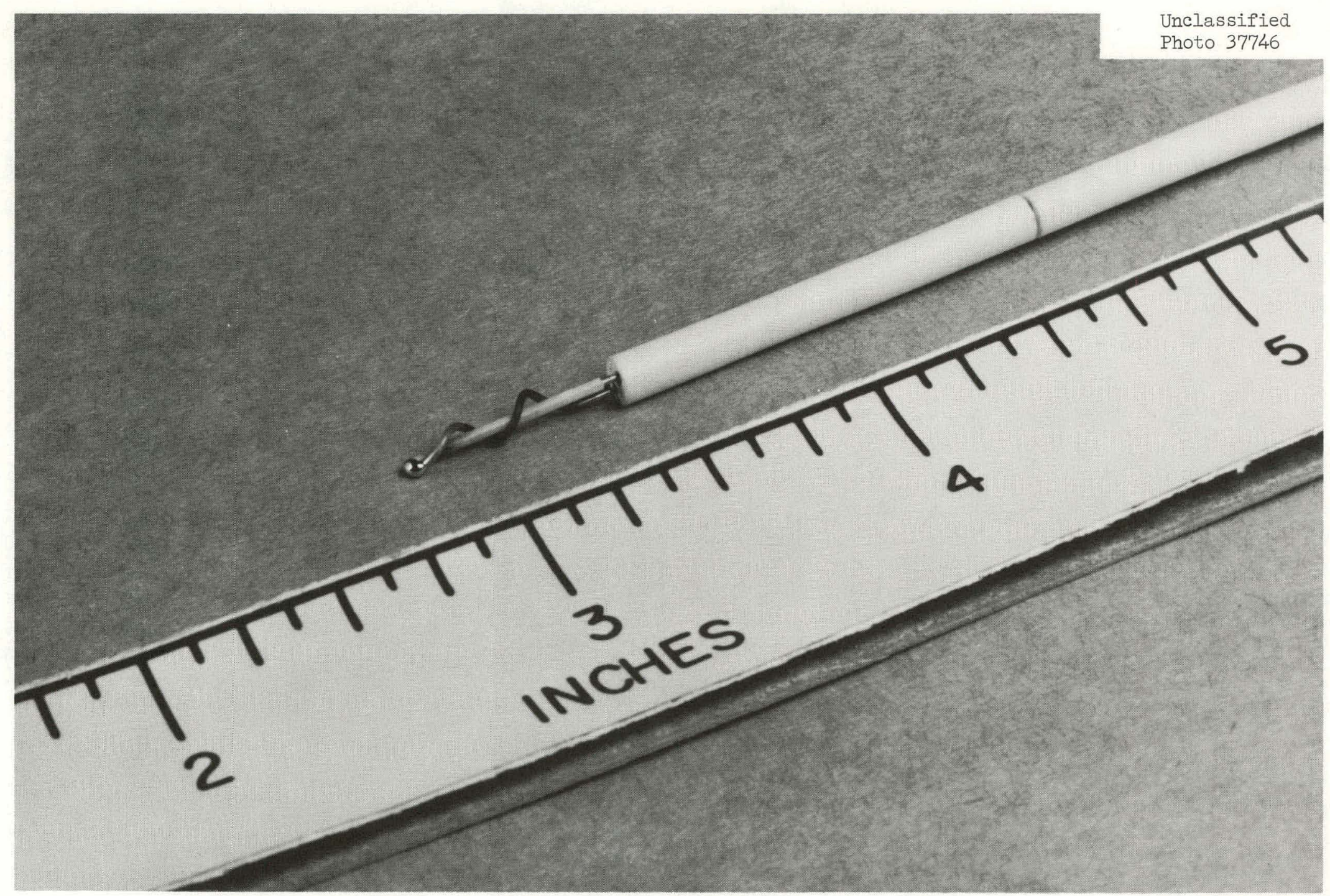

Fig. 66. Tungsten vs Rhenium Thermocouple Assembly with BeO Insula- 


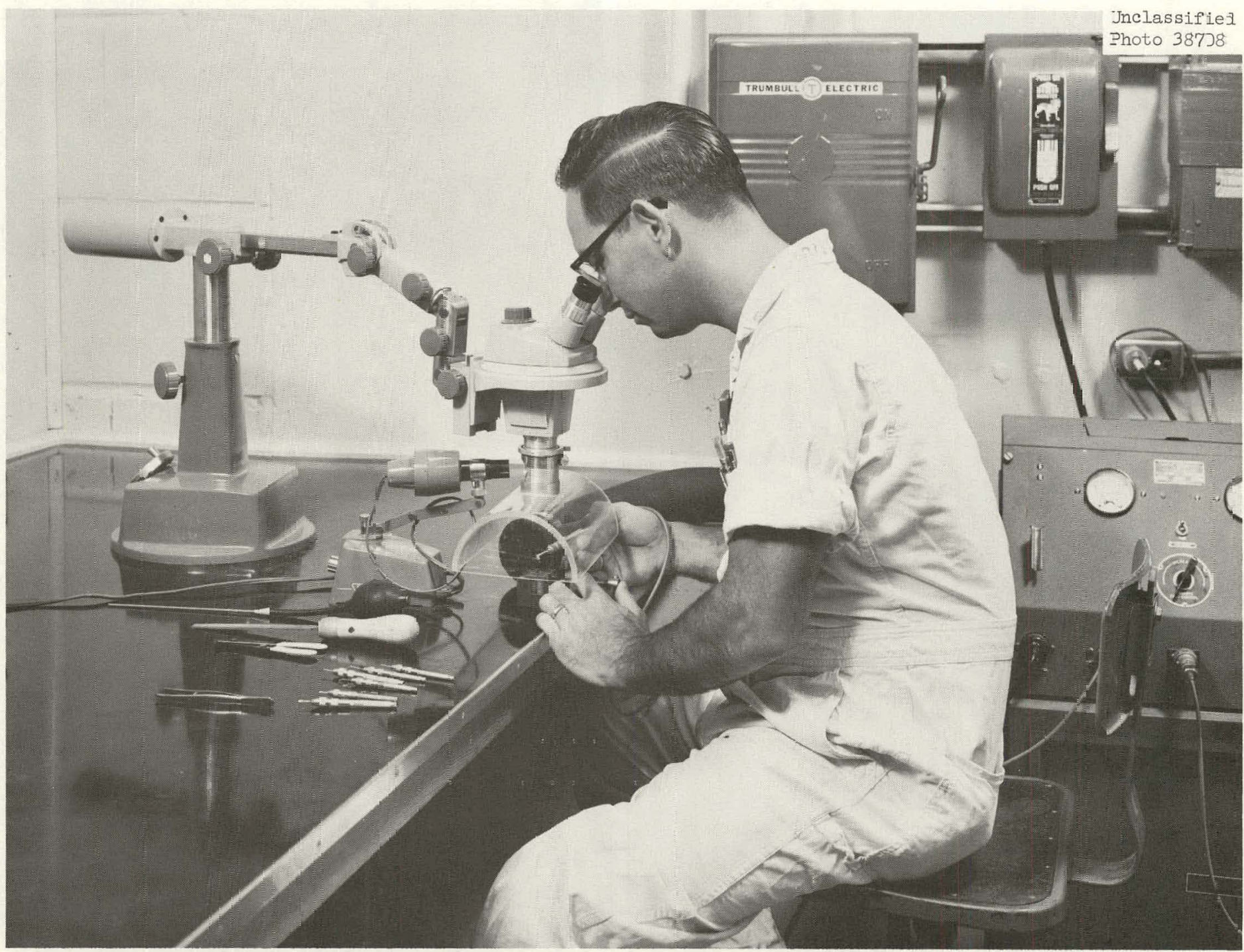

F-g. 67. Instrument Mecharic Prepaing Sheathed Thermocouples for Welding of Irsulated Junctions. 


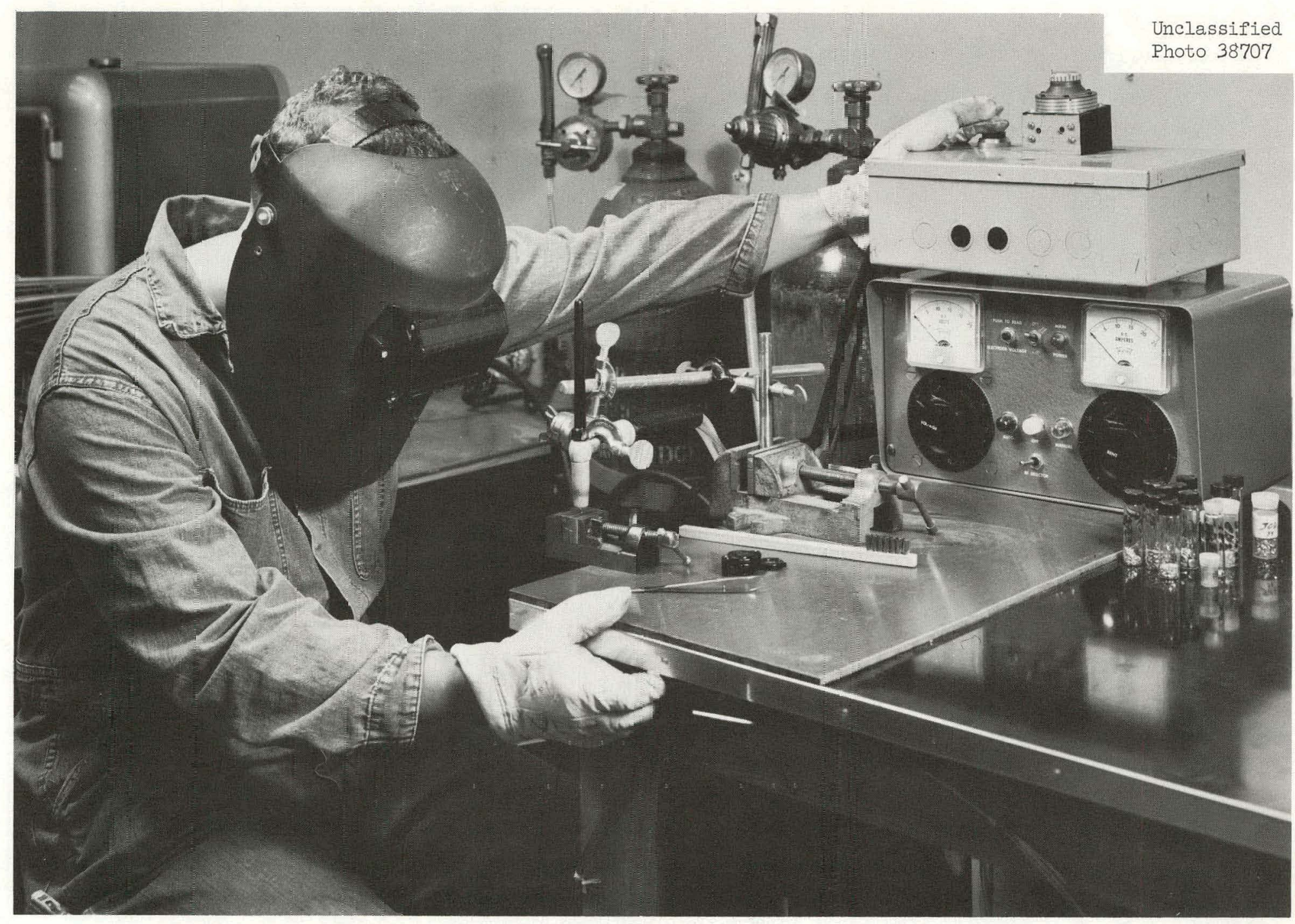

Fig. 68. Welder Making Thermocouple Junctions with Semiautomatic Welding Equipment. 


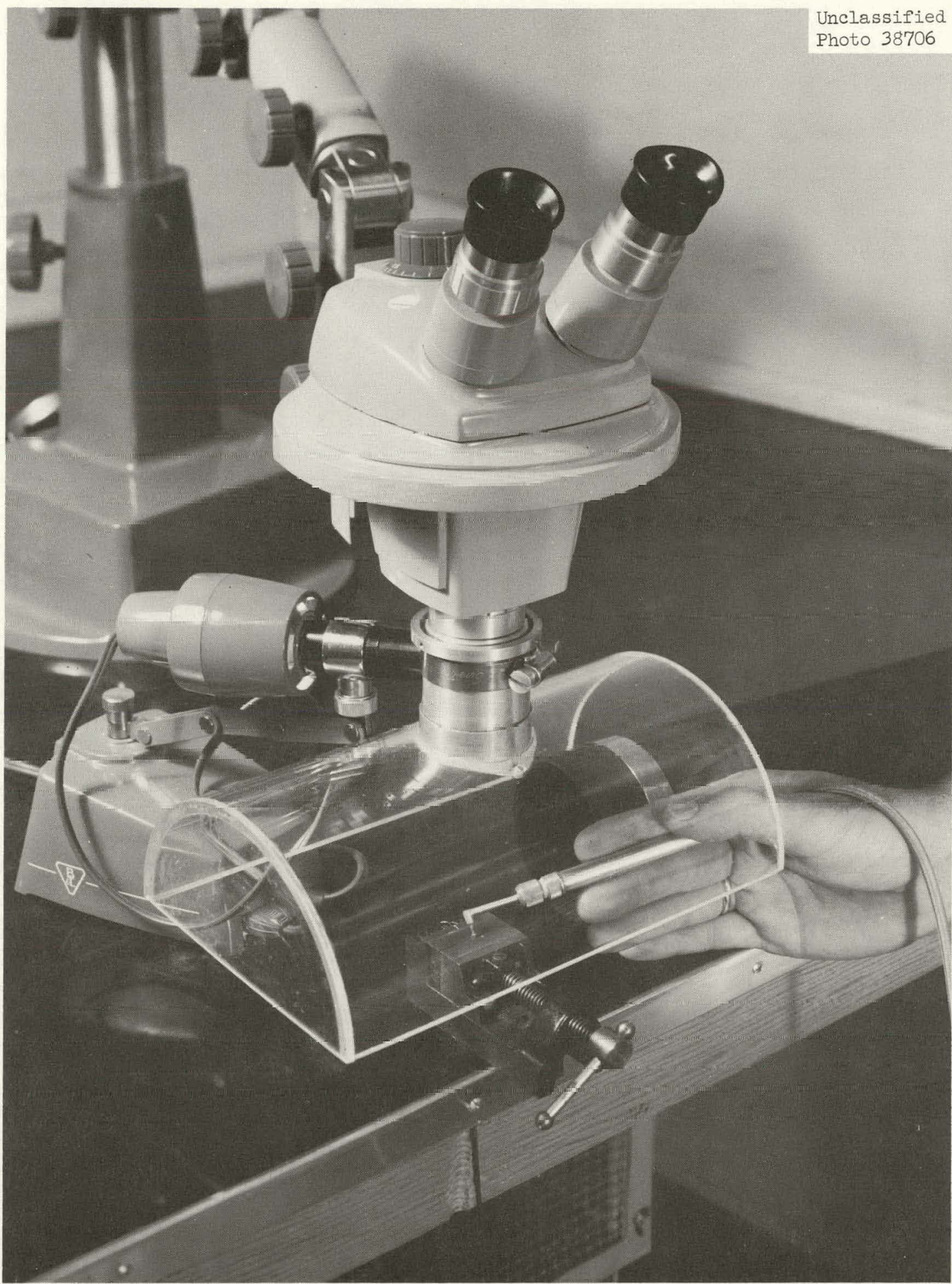

Fig. 69. Closeup of Binocular Microscope and Blasting Gun Used to Prepare Sheathed Thermocouples for Welding Insulated Junctions. 


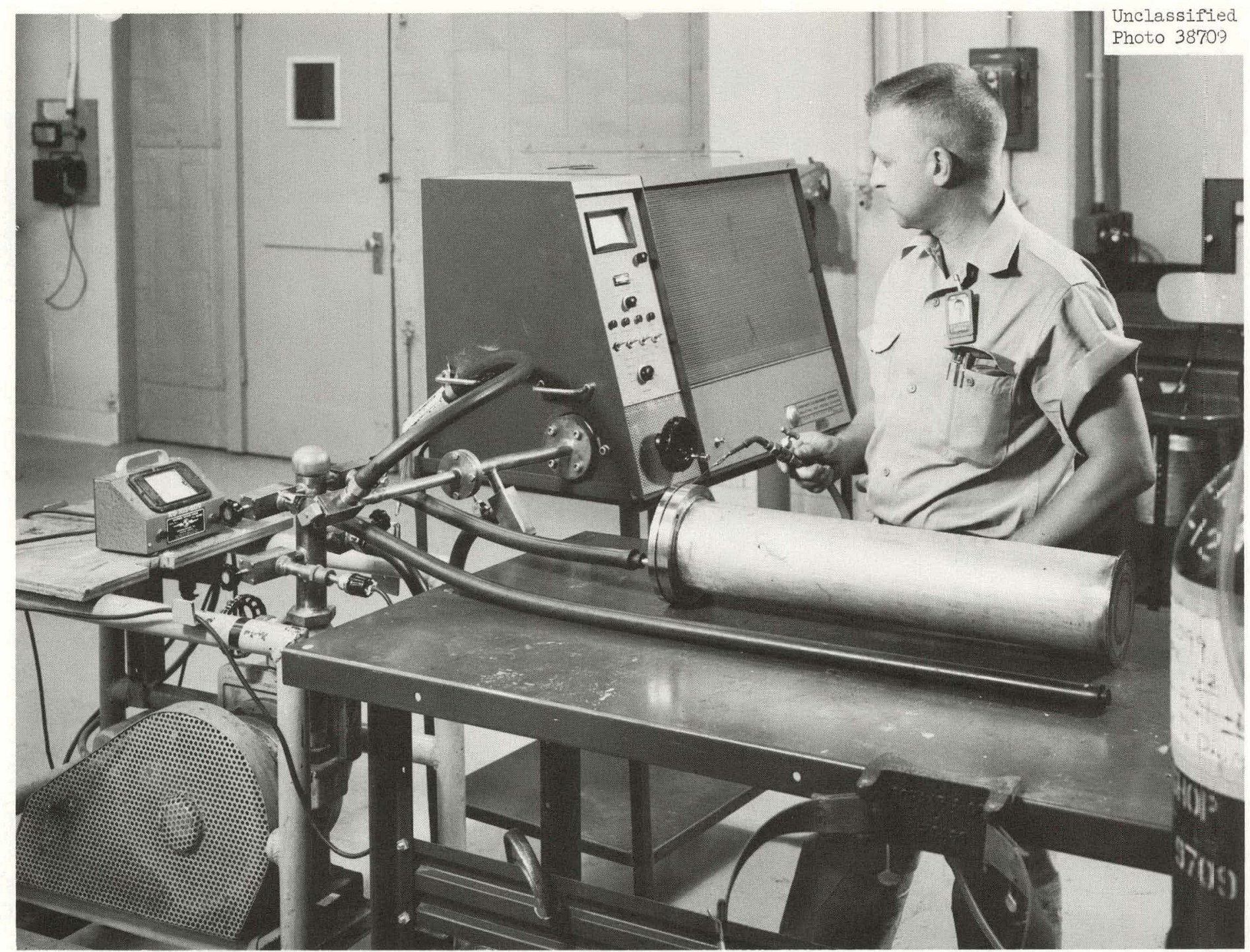

Fig. 70. Helium Leak Checking a Container with Mass SpectrometerType Leak Detector. 


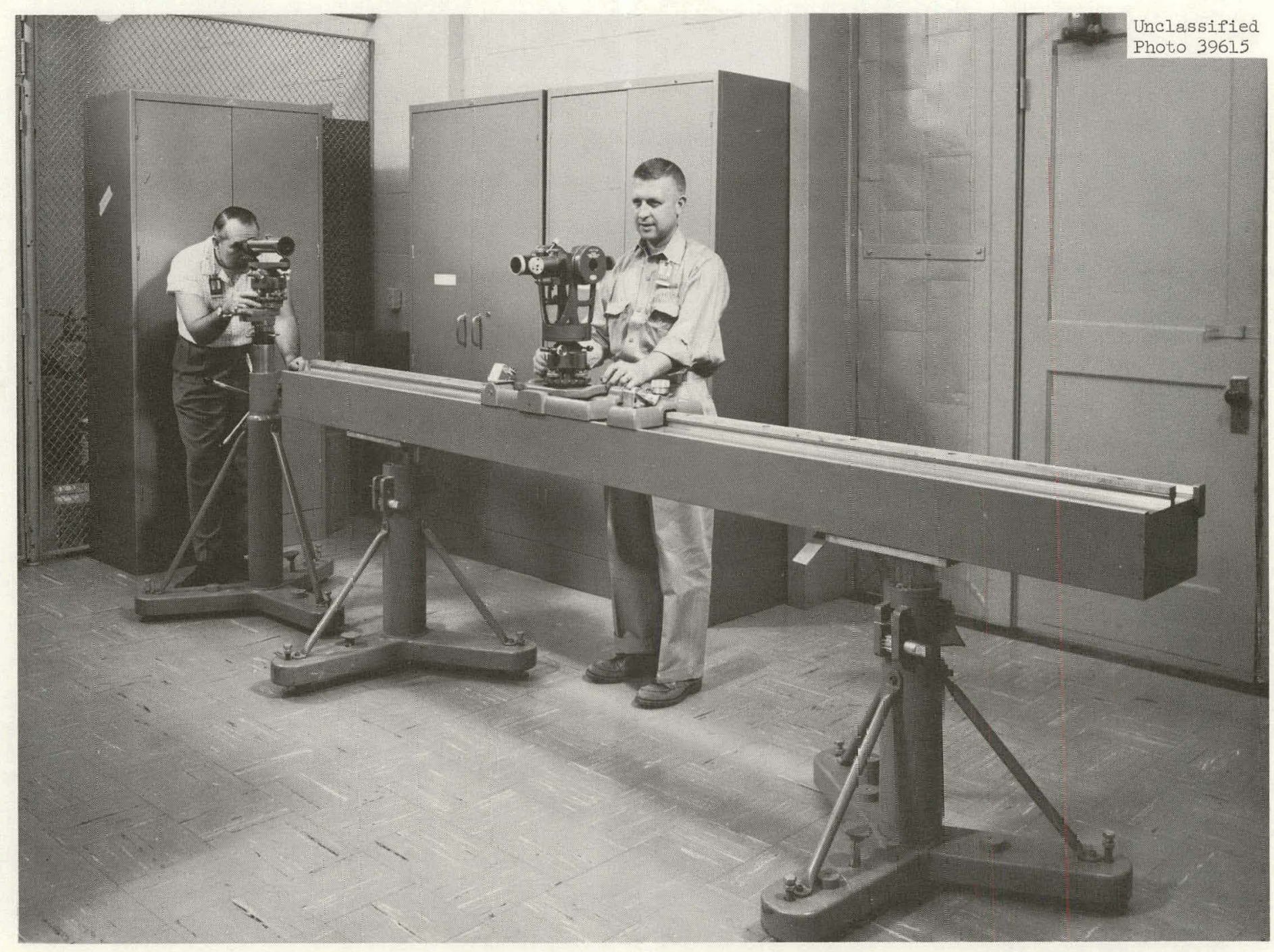

Fig. 71. Brunson Optical Tooling Equipnent. 


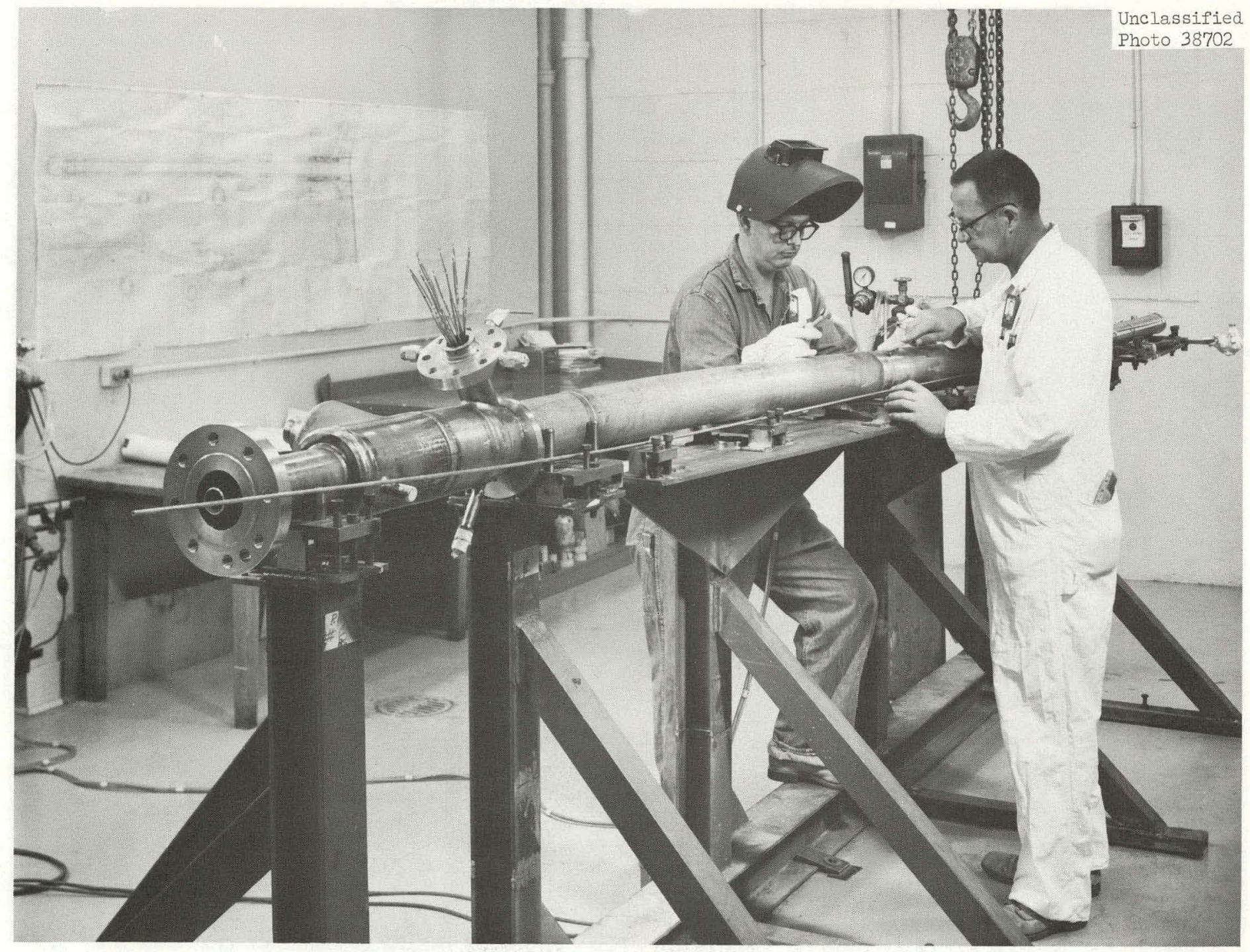

Fig. 72. Loop I-S In-Pile Section on Assembly Fixture. 


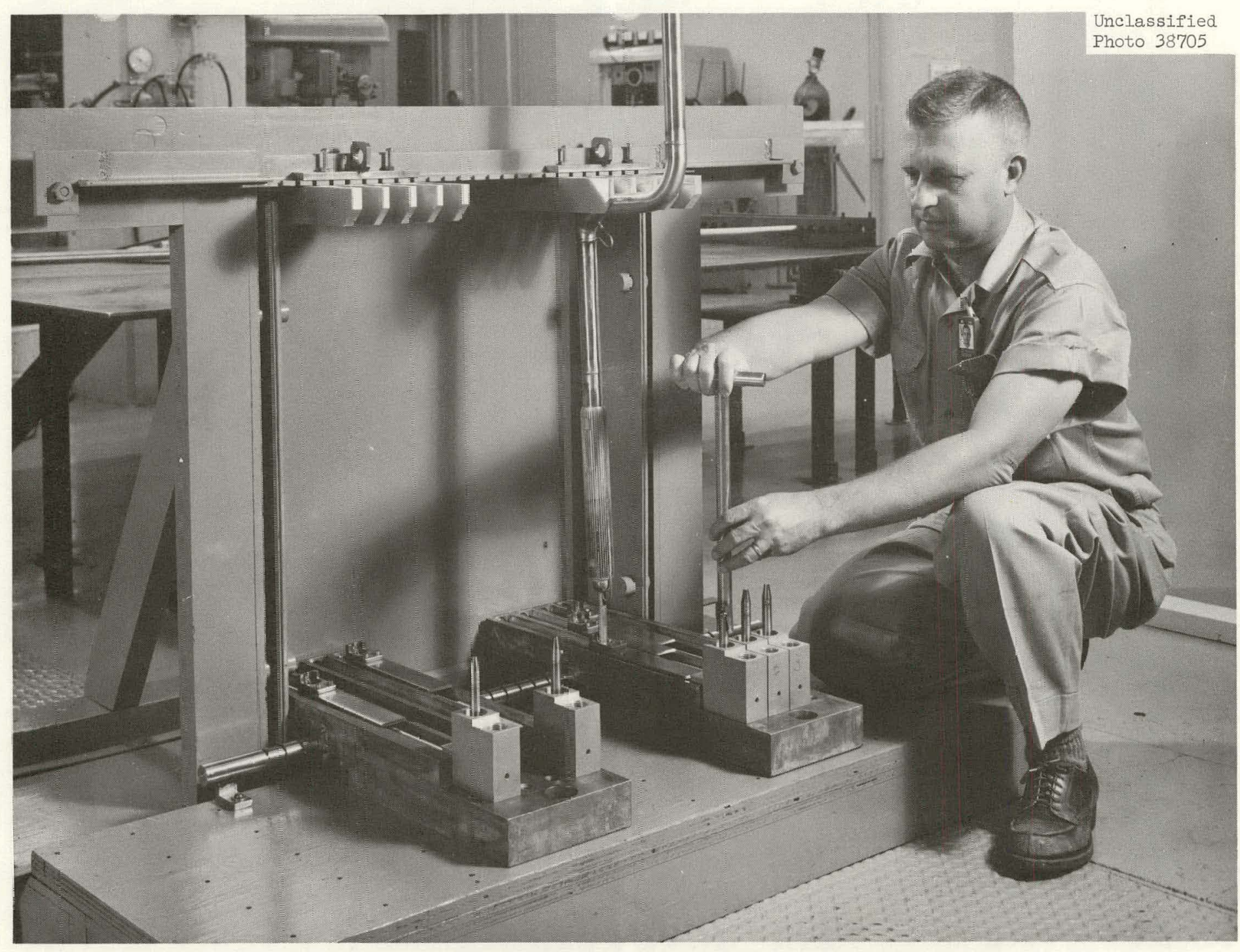

Fig. 73. ORR Poolside Facility Mockup Showing ORR Capsule in Positioning Mechanisn Which Duplicates Installetion at the Reactor. 


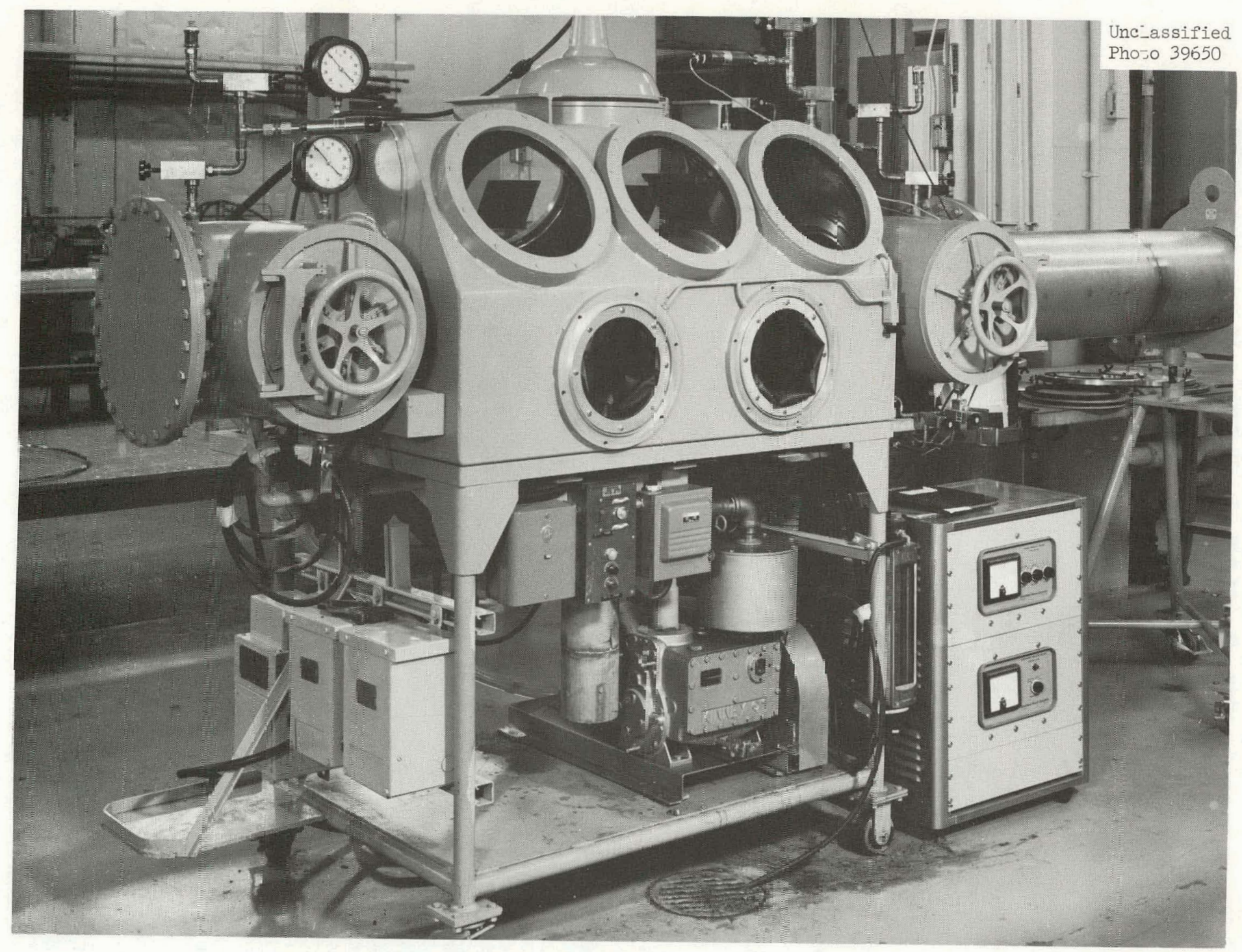

Fið. 74. Blickman Welding Chamber in Assembly Area. 


\section{ACKINOWLEDGEMENTS}

The work described represents the combined efforts of many individuals. Engineers and scientists currently engaged in fuel-irradiation testing as group leaders and as task engineers, respectively, are: J. A. Conlin, I. T. Dudley, J. K. Franzreb, F. R. McQuilkin, A. A. Abbatiello, C. A. Brandon, V. A. DeCarlo, A. W. Longest, W. R. Mixon, I. K. Namba, C. L. Segaser, R. L. Senn, and D. E. Tidwell. In addition to members of the Irradiation Engineering Department of the Reactor Division, members of many other divisions of ORNL have participated in this work. Contributions have been made particularly by Metals and Ceramics, Instrumentation and Controls, Reactor Operations, Reactor Chemistry, Plant and Equipment, and Solid State Divisions. Much assistance has been provided by both the $Y-12$ and Gaseous Diffusion Plant forces. Members of the Phillips Petroleum Co. at NRTS have contributed much to work conducted at that site. ORNL management and the AEC staff members have been most helpful. 


\section{REF ERENCES}

1. A. M. Weinberg, T. E. Cole, and M. M. Mann, "The Materials Testing Reactor and Related Research Reactors," Proceedings of the International Conference on the Peaceful Uses of Atomic Energy, Geneva, 1955, Vol. 2, pp. 402-419, United Nations, New York, 1956.

2. J. H. Buck, "The Materials Testing Reactor Project Handbook, "USAEC Report TID-7001, May 1951.

3. T. E. Cole and J. P. Gill, "The ORNL Research Reactor (ORR) A General Description," USAEC Report ORNL-2240, Oak Ridge National Laboratory, January 1957.

4. A. S. Richardson et al., "In-Tank Irradiation Facilities in the MIREIR, Standard Practice Manual," USAEC Report IDO-16428, Revised, Phillips Petroleum Company, March 1963.

5. ASME Boiler and Pressure Vessel Code, Section VIII, "Rules for Construction of Unfired Pressure Vessels," The American Society of Mechanical Engineers, United Engineering Center, 2nd Ed., New York, New York.

6. ASME Boiler and Pressure Vessel Code, Section III, "Rules for Construction of Nuclear Vessels," The American Society of Mechanical Engineers, United Engineering Center, New York, New York (to be published).

7. "Tentative Structural Design Basis for Reactor Pressure Vessels and Directly Associated Components (Pressurized Water-Cooled Systems)," Office of Technical Services, Department of Commerce, PB-151987, December 1958.

8. The American Standards Association, "Code for Pressure Piping," ASA B31.la-1961, New York, New York, 1961 Edition.

9. H. M. Glen, "The Manipulator Hot Cells Above the Oak Ridge Research Reactor Pool," 6th Hot Laboratory and Equipment Conference, March 1958, Chicago, Illinois.

10. C. D. Watson et al., Proceedings of the 8 th Conference on Hot Laboratories and Equipment, Book 2, pp. 337-357, USAEC Report TID-7599, December 1960.

11. H. M. Glen, "Alteration of a Gamma Cell for Plutonium-Gamma Usage," Nuclear Engineering and Science Conference, Preprint V-34, Cleveland, Ohio, April 1959. 
12. A. R. Olsen, "A New Postirradiation Examination Laboratory at the Oak Ridge National Laboratory," Proceedings of the 9th Conference on Hot Laboratories and Equipment, Sponsored by the Hot Laboratory Division of ANS, Chicago, Illinois, November 1961.

13. K. D. George, "The Oak Ridge Reactor (ORR), The Low Intensity Testing Reactor (IITR), and the Oak Ridge Graphite Reactor (OGR), As Experiment Facilities," USAEC Report ORNL-TM-279, Oak Ridge National Laboratory, August 1962.

14. D. B. Trauger, "Irradiation Testing of Fuel Materials for EGCR," Nucl. Sci. Eng., 14(1): 69-82 (1962).

15. J. G. Morgan, M. F. Osborne, and O. Sisman, "Irradiation Effects in the FGCR Fue1," Nucl. Sci. Eng., 14: 83-100 (1962).

16. Oak Ridge National Laboratory, Beryllium Cladding and $\mathrm{UO}_{2}$ Grain-Size Studies, p. 107, "GCRP Quar. Prog. Rep. Sept. 30, 1960," USAEC Report ORNL-3015.

17. W. O. Harms and G. Samuels, Fuel Element Design Criteria, pp. 276279, "GCRP Semiann. Prog. Rep. Sept. 30, 1963," USAEC Report ORNL3523, Oak Ridge National Laboratory.

18. Oak Ridge National Laboratory, "Conceptual Design of the Pebble Bed Reactor Experiment," USAEC Report ORNL-TM-201, May 1962.

19. A. T. Chapman, R. I. Hamner, and R. E. Meadows, Fabrication of Fueled Be0, pp. 212-221, "GCRP Semiann. Prog. Rep. Sept. 30, 1963," USAEC Report ORNL-3523, Oak Ridge National Laboratory.

20. C. W. Townley, N. E. Mitler, T. S. Ellerman, and D. N. Sunderman, "An Improved Technique for the Determination of Short-Lived FissionProduct Gases," Nucl. Sc1. Eng., 13(3): 297-298 (July 1962).

21. R. M. Carroll, "Argon Activation Measures Irradiation Flux Continuously," Nucleonics, 20(2): 42-43 (February 1962).

22. E. H. Porter, "The Design, Installation, and Testing of the GasCooled Reactor $\mathrm{UO}_{2}$ Irradiation Experiments at the NRTS," USAEC Report IDO-16646, Phillips Petroleum Company, September 1961.

23. W. O. Harms, "Coated Particle Fuel Development at Oak Ridge National Laboratory," USAEC Report ORNL-TM-431, Oak Ridge National Laboratory, Feliruly 1963.

24. J. C. Lachman and J. A. McGurty, pp. 177-187 in Temperature, Its Measurement and Control in Science and Industry, Vol. 3, Part 2, Reinhold Publishing Corp., New York, 1962. 
25. J. K. Franzreb, Irradiation Tests in GCR-ORR Loop No. 1, pp. 60-69, "GCRP Quar. Prog. Rep. Dec. 31, 1961," USAEC Report ORNL-3254, Oak Ridge National Laboratory.

26. Oak Ridge National Laboratory, "The ORNL GCR-3, A 750-Mw(e) GasCooled Clad-Fuel Reactor Power Plant," USAEC Report ORNL-3353, December 1962.

27. J. K. Franzreb and A. W. Longest, GCR-ORR Loop No. 1 Tests of Clad Fuel Elements, pp. 206-212, "GCRP Semiann. Prog. Rep. Sept. 30, 1963," USAEC Report ORNL-3523, Oak Ridge National Laboratory.

28. J. Zasler, W. R. Huntley, P. A. Gnadt, and T. S. Kress, "In-Pile Gas-Cooled Fuel Element Test Facility," USAEC Report ORNL-TM-250, Oak Ridge National Laboratory, July 1962.

29. Babcock and Wilcox Company, "Nuclear Merchant Ship Reactor Project, Final Safeguards Report," Vol. 1, USAEC Report BAW-1164, 1961.

30. C. L. Whitmarsh, "Potential Fuel Cycle Cost Savings from Technological Changes in the N.S. SAVANVAH Reactor," USAEC Report ORNL-TM-144, Oak Ridge National Laboratory, April 1962.

31. I. T. Dudley, D. E. Tidwell, and D. B. Trauger, "Design Report for NMSR Pressurized-Water Loop at ORR," USAEC Report ORNL-3188, Oak Ridge National Laboratory, December 1962.

32. C. Eicheldinger et al., "PM Fuel Specimen Irradiation Program," USAEC Report MND-MD-2954 (to be published), The Martin Company.

33. D. B. Trauger and J. A. Conlin, Jr., "Circulating Fused-Salt Fuel Irradiation Test Loop," Nucl. Sci. Eng., 9(1): 346-356 (March 1961).

34. Oak Ridge National Laboratory, "MSRP Semiann. Prog. Rep. Aug. 31, 1962," pp. 100-116, USAEC Report ORNL-3369.

35. C. W. Curningham ard J. A. Conlin, MTR Irradiations, pp. 216-220, "GCRP Quar. Prog. Rep. March 31, 1962," USAEC Report ORNL-3302, Oak Ridge National Laboratory.

36. A. L. Boch, E. S. Bettis, and W. B. McDonald, "The Molten-Salt Reactor Experiment," Proceedings of the IAEA Symposium on Power Reactor Experiments held in Vienna, Austria, October 1961 (to be published).

37. National Carbon Company, "Summary Report - Phase 1 - Graphite-Matrix Nuclear Fuel Elements," USAEC Report ORO-240, Vol. 1, December 1959.

38. R. L. Senn, FGCR Instrumented Fuel Assemblies, "GCRP Semiann. Prog. Rep. Sept. 30, 1963," pp. 47-56, USAEC Report ORNL-3302, Oak Ridge National Laboratory. 
39. W. C. Kuhlman, "Research and Evaluation of Materials for Thermocouple Application Suitable for Temperature Measurements up to $4500^{\circ} \mathrm{F}$ on the Surface of Glide Re-Entry Vehicles, "USAEC Report ASD-TDR-63-233, General Electric Company, May 1963.

40. B. F. Hall, Jr., and Norman F. Spooner, "Application and Performance Data for Tungsten-Rhenium Alloy Thermocouples," Society of Automotive Engineers Paper No. 750C, September 1963. 
THIS PAGE

\section{WAS INTENTIONALLY \\ LEFT BLANK}




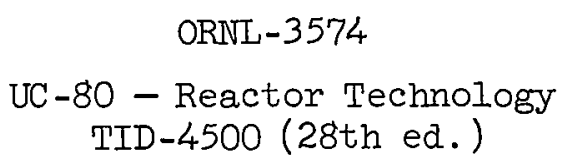

Internal Distribution

1. R. E. Adams

2. R. G. Affel.

3. E. D. Arnold

4. Russell Baldock

5. C. D. Baumann

6. S. E. Beall

7. F. F. Blankenship

8. E. S. Bomar

9. C. A. Brandon

10. F. L. Carlsen, Jr.

11. C. E. Center $(\mathrm{K}-25)$

12. C. J. Claffey

13. W. B. Cottrell

14. J. A. Cox

15. F. L. Culler

16. I. T. Dudley

17. D. A. Gardiner

18. R. G. Gilliland

19. W. Y. Gissel

20. P. A. Gnadt

21. A. E. Goldman

22. J. P. Harmond

23. F. F. Haywood

24. D. M. Hewette

25. E. C. Hise

26. W. R. Huntley

27. G. H. Jenks

28. T. S. Kress

29. C. ए. Lamb

30. J. A. Lane

31. C. E. Larson $(\mathrm{K}-25)$

32. J. E. Lee, Jr.

33. C. S. Lisser

34. H. G. MacPherson

35-101. W. D. Manly

102. M. M. Martin

103. H. E. MeCoy

104. H. F. McDuffie

105. F. R. McQuilkin

106̂. J. K. McWherter

107. E. C. Miller
108. W. R. Mixon

109. J. G. Morgan

110. J. F. Murdock

Ill. F. H. Neill

112. A. R. Olsen

113. L. F. Parsly

114. C. E. Powell

115. S. A. Rabin

116. M. W. Rosenthal

117. D. P. Roux

118. G. Samuels

119. H. C. Savage

120. H. W. Savage

121. A. W. Savolainen

122. J. L. Scott

123. R. L. Senn

124. R. P. Shields

125. M. D. Silverman

126. M. J. Skinner

127. J. A. Swartout

128. W. C. Thurber

129. D. E. Tidwell

130. G. M. Tolson

131. D. B. Trauger

132. J. W. UIImann

133. J. T. Venard

134. G. M. Watson

135. $\Lambda$. M. Weinberg

136. W. J. Werner

137. F. C. Zapp

138. Jack Zasler

139-141. Central Research Library

142-144. Y-12 Document Reference Section

145-236. Laboratory Records Department

237. Laboratory Recoras, R.C. 
Extermal Distribution

238. R. E. Anderson, AEC Washington, D.C.

239-241. P. D. Bush, Kaiser Engineers

242. R. A. Charpie, UCC Research Administration, New York, N.Y.

243. W. R. Cooper, Tennessee Valley Authority

244-245. D. F. Cope, Reactor Division, AEC, ORO

246-247. R. W. Coyle, Vallecitos Atomic Laboratory

248. E. Creutz, General Atomic

249-251. R. B. Duffield, General Atomic

252 C. Eicheldinger, Martin Company, Baltimore, Maryland

253. H. L. Falkenberry, Tennessee Valley Authority

254. D. H. Fax, Westinghouse Atomlc Puwer Division

255. M. H. Foster, NASA, Zeus Project Office, Huntsville, Alabama

256. W. C. Francis, Phillips Petroleum Company

257. W. A. Giardini, Brown Engineering Co., Huntsville, Alabama

258. M. Janes, National Carbon Research Laboratories, Cleveland, Ohio

259. T. Jarvis, Ford Instrument Company

260. James R. Johnson, Minnesota Mining and Manufacturing Company, Saint Paul, Minn.

261. S. J. Kaufman, NASA, Lewis Research Center, Cleveland, Ohio

262. R. F. Kirkpatrick, AEC, Washington

263. R. J. Klotzbock, UCND, Sterling Forest

264. C. W. Kuhlman, United Nuclear Corp.

265. W. J. Larkin, AEC, ORO

266-267. H. Lichtenburger, General Nuclear Engineering Corp.

268. J. M. Martin, AEC, ORO

269-271. S. Matovich, Allis-Chalmers Mfg. Co.

272. J. P. McGee, Bureau of Mines, Appalachian Experiment Station

273 F. L. McMillan, Phillips Petroleum Company

274. R. W. McNamee, UCC Research Adminctration, New York, N.Y.

275. R. E. Pahler, Reactor Division, AEC, Washington

276 H. B. Rahner, Savannah River Operations Office

277. W. L. R. Rice, AEC, Washington

278. Corwin Rickard, General Atomic

279. J. M. S1mmons, AEC, Washington

280. M. T. Simnad, General Atomic

281. Nathanial Stetson, Savannah River Operations Office

282. Donald Stewart, AEC, Washington

283. R. G. Sturm, Brown Engineering Co., Huntsville, Alabama (Staff Conoultant)

284. S. A. Szawlewiez, AEC, Research and Development Branch, Division of Reactor Development

285. C. H. Tarrant, AEC, ORO

286. Philip L. Walker, Pennsylvania State University

287. R. E. Watt, Los Alamos Scientific Laboratory

288-289. W. L. Webb, East Central Nuclear Group, Inc.

290. M. J. Whitman, AEC, Washington

291. C. E. Winters, UCC, Cleveland, Ohio 
292. Lloyd R. Zumwalt, General Atomic

293. Division of Research and Development, AEC, ORO

294-900. Given distribution as shown in TID-4500 (28th ed.) under Reactor Technology category ( 75 copies - OTS) 